\title{
LÍDIA SPAZIANI
}

A gramaticalização do item fora no Português do Brasil: a unidirecionalidade do processo.

Programa de Pós-Graduação em Filologia e Língua Portuguesa UNIVERSIDADE DE SÃO PAULO - USP/ SP 


\section{LÍDIA SPAZIANI}

\section{A gramaticalização do item fora no Português do Brasil: a unidirecionalidade do processo.}

Dissertação de Mestrado apresentada ao Programa de Pós-Graduação em Filologia e Língua Portuguesa da Universidade de São Paulo, como requisito parcial para a obtenção do título de Mestre em Filologia e Língua Portuguesa.

Orientadora: Profa. Dra. Maria Célia Lima-Hernandes

\footnotetext{
Programa de Pós-Graduação em Filologia e Língua Portuguesa UNIVERSIDADE DE SÃO PAULO - USP/ SP 
Banca Examinadora:

Profa. Dra. Maria Célia Lima-Hernandes (orientadora-USP)

Prof. Dr. Osvaldo Humberto Leonardi Ceschin (Universidade de São Paulo)

Profa. Dra. Liliane Santos (Université Charles-de-Gaulle Lille III)

Membros suplentes

Prof. Dr. Sebastião Carlos Gonçalves (UNESP-Rio Preto)

Prof. Dr. Manoel Mourivaldo Santiago Almeida (USP)

Vânia Cristina Casseb-Galvão (UFG) 


\title{
Dedicatória
}

\begin{abstract}
À minha mãe, aos meus irmãos, filho, amigos e a todos os mestres de estudo, vida e alma que me mostraram o caminho unidirecional, o do saber.
\end{abstract}




\section{AGRADECIMENTOS}

A Deus, em Quem me lançava quando os momentos mais turbulentos pareciam estancar minhas idéias, meus ideais e minha determinação.

À minha orientadora, Profa. Dra.Maria Célia Pereira Lima-Hernandes, pelos incomensuráveis estímulo e contribuição no plano intelectual e emocional, pela compreensão frente a tantas condições pouco favoráveis no período em que a pesquisa ocorreu, pela sempre presente amizade e por acreditar em mim e me auxiliar.

Aos Professores do Programa de Pós-Graduação em Filologia e Língua Portuguesa (FFLCH), pelas constantes demonstrações de competência e respeito ao solo acadêmico; por me ensinarem, unanimemente, a ser pesquisadora, fato que revitalizou minha prática docente.

Ao Prof. Dr. Osvaldo Humberto Leonardi Ceschin e à Profa. Dra. Liliane Santos, que levantaram questões importantíssimas para o desenvolvimento da pesquisa e, conseqüentemente, para o meu desempenho intelectual.

Se fosse viável, agradeceria ao citar o nome de cada um dos meus colegas do curso da pós-graduação que, de forma direta, pelos caminhos de interesses comuns, me auxiliaram tanto em leitura quanto em idéias novas para a produção desta pesquisa. Pelos inúmeros momentos em que me trouxeram à luz da realidade, quando a ansiedade me levava à utopia ou a um mundo de inseguranças.

A Kelly Viviane Bernardo, Paulo Henrique de Oliveira Barroso, Cristina Lopomo Defendi e Elisângela Baptista de Godoy Sartin, como colegas de estudo, pelo olhar de curiosidade frente aos textos e pelos assuntos que, mesmo quando na informalidade, voltavam-se à pesquisa. Como amigos, parceiros nas resoluções ou acréscimos das infindas dúvidas provenientes do crescimento, e presentes nos momentos em que precisei. 
A outros colegas e amigos (Aida Hanania, Reinaldo Rossi, Maria Cláudia de Góes, entre outros) que entenderam, com compreensão, a ausência social, decorrente do tempo sempre escasso quando se pesquisa, auxiliando-me com preces, energias, orações e todo tipo de mentalizações e atitudes, para que a calma e a coerência fossem minhas companheiras.

Ao meu pai, Mário Spaziani (in memoriam), pela integridade que tão bem me ensinou. À minha mãe, Iracema Olivieri Spaziani, pelo amor incondicional que me renovava e ainda renova a cada momento. Aos meus irmãos, Lúcia Spaziani, Mário Spaziani e ao meu cunhado e amigo, Pablo José Sanchez-Crespo Zenner, às amigas Sandra K. Kusaba Buff e Eliane Bandeira que supriram a minha falta no contexto familiar; à minha irmã Rosângela Spaziani, que, além de me orientar psíquica e espiritualmente, sempre esteve e está presente em minhas decisões.

À riqueza da minha vida, meu filho Matheus, a quem agradeço pelas inúmeras interrupções nesta pesquisa para as constantes demonstrações de carinho.

A Anauel, Bianca, Leona, Mel e Piquerru pelas freqüentes demonstrações de alegria e silenciosa cumplicidade. 
Sonnet 76- “(...)Why write I still all one, ever the same, And keep invention in a noted weed, That every word doth almost tell my name, Showing their birth, and where they did proceed?

Por que escrevo apenas sempre o mesmo E escondo o achado em hábitos banais, Tanto que as palavras quase nunca a esmo Mostram meu nome e a mim como seus pais?(...)"

(Soneto 76 - William Shakespeare) 


\section{Sumário}

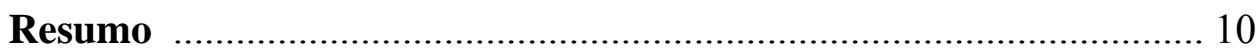

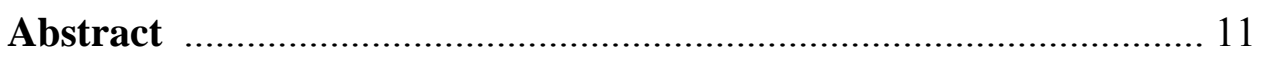

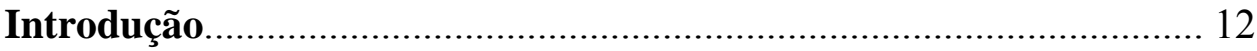

Capítulo I: Fundamentação teórica _................................................... 19

1. Definições de gramaticalização .......................................................... 19

2. Mecanismos de mudança ..................................................................... 23

3. Abordagens sincrônica e diacrônica...................................................... 27

4. Princípios da gramaticalização ............................................................. 29

Capítulo II: Aspectos Metodológicos ….......................................... 34

1. As amostras de língua portuguesa................................................... 34

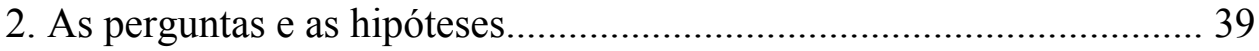

Capítulo III: A palavra fora no Português do Brasil .......................... 42

1. Etimologia da palavra fora e seus deslizamentos funcionais................42

2. Comparando com acepções assumidas historicamente.........................58

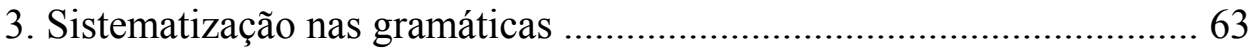

4. Padrões funcionais do item fora no português do Brasil.......................65

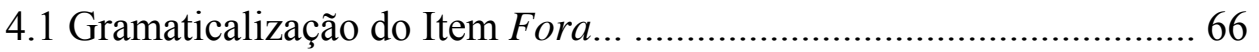

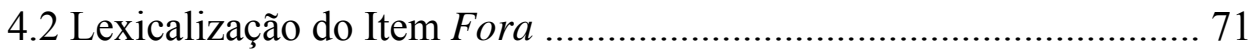




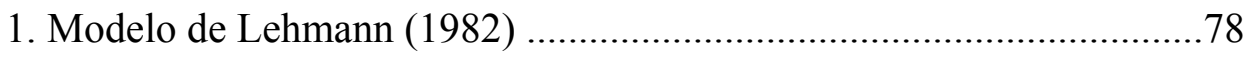

2. Modelo de Hopper (1991) ......................................................... 82

3. Modelo de Heine, Claudi \& Hünnemeyer (1991) ............................ 87

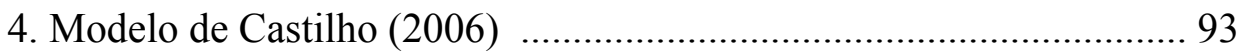

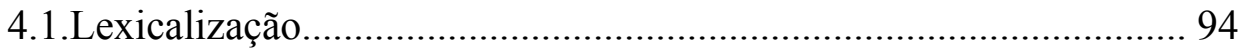

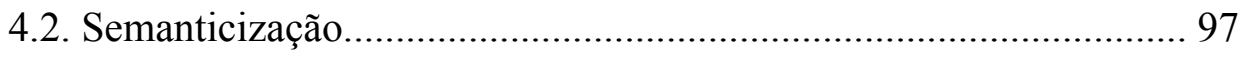

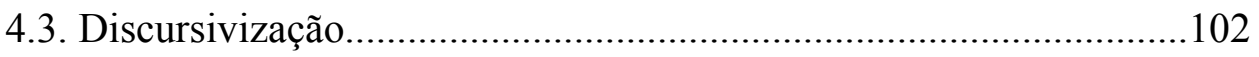

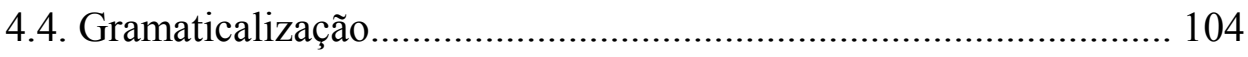

5. Os padrões funcionais e as amostras estudadas...................................108

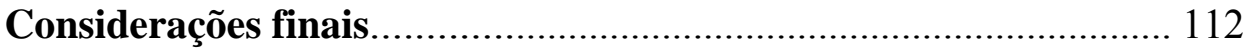

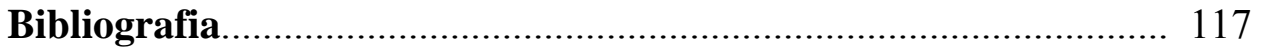

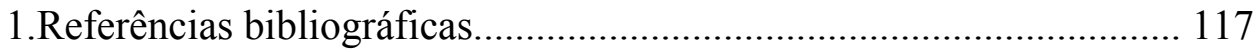

2.Referências bibliográficas virtuais................................................... 121

Anexo 1: Dados colhidos de blogs e orkuts, PEUL e dissertações ..........122

Anexo 2: Dados de contato e recontato PEUL ...................................... 131 


\section{Resumo}

Num arcabouço teórico funcionalista que prioriza o estudo da língua em constante mudança a partir de seu uso (HALLIDAY, 1978), analisam-se as alterações gramaticais e semânticas de um item lexical que sofre gramaticalização no português do Brasil. O objetivo mais geral é avaliar a diferença existente entre os modelos de análises propostos por Lehmann (1982), Hopper (1991), Heine, Claudi e Hünnemeyer (1991) e Castilho (2006), quando aplicados a dados das modalidades falada e escrita. O item escolhido para proceder ao estudo é o item-fonte adverbial FORA, que revela um percurso unidirecional no processo de gramaticalização. Evidencia-se que a essa unidireção subjaz uma rota de abstratização funcional bastante intensa que culmina com sua recategorização em item gramatical.

PALAVRAS-CHAVE: advérbio; funcionalismo; mudança lingüística; gramaticalização; unidirecionalidade. 


\begin{abstract}
In a theoretical functionalist framework, which prioritizes the study of the language in constant change from its use (HALLIDAY, 1978), it is analyzed the grammatical and semantic alterations on a lexical item that suffers grammaticalization in the Portuguese from Brazil. The most general objective is to evaluate the existing difference among the models of analyses considered by Lehmann (1982), Hopper (1991), Heine, Claudi and Hünnemeyer (1991) and Castilho (2006), when applied the data of the spoken and written modalities. The chosen item to proceed the study is the adverbial item-source FORA (out), that discloses a unidirectional passage in the grammaticalization process. It is evident that to this unidirection implies to a route of sufficiently intense functional abstraction that culminates with its recategorization in the grammatical item.
\end{abstract}

KEYWORDS: adverb; functionalism; linguistic change; grammaticalization; unidirectionality. 


\section{Introdução}

O presente estudo tem como objetivo avaliar a diferença existente entre os modelos de análises propostos por Lehmann (1982), Hopper (1991), Heine, Claudi e Hünnemeyer (1991) e Castilho (2006) num arcabouço teórico funcionalista dos estudos sobre gramaticalização, especificamente avaliando o princípio da unidirecionalidade, a partir de dados das modalidades falada e escrita da língua portuguesa.

Como forma de verificar a similaridade e as diferenças entre os modelos, selecionamos uma palavra que tem empreendido uma rota de gramaticalização bastante interessante, conforme descrição observada em Spaziani (2007): a palavra $\boldsymbol{F O R A}^{1}$ em usos sincrônicos do português do Brasil.

Para que se reconheça a trajetória de desenvolvimentos dos três modelos anteriormente citados, iniciamos esta dissertação com uma exposição que parte dos recortes teóricos sobre gramaticalização: sua conceituação, abordagens desenvolvidas, mecanismos e direção da mudança.

É relevante ressaltar que os modelos de análise amplamente utilizados pelos lingüistas são, em grande parte, derivados das intuições e descobertas a que chegaram os grupos de pesquisas alemães e norte-americanos. Muito do que eles afirmam hoje, entretanto, são idéias remanescentes das descobertas do início do século XX na França por Meillet (1912, apud GONÇALVES, LIMA-HERNANDES \& CASSEB-GALVÃO, 2007).

Mais ainda relevante torna-se explanar um modelo brasileiro que causa polêmica por estrear na literatura lingüística já refutando alguns princípios teóricos que subjazem

\footnotetext{
${ }^{1}$ Os termos palavra e item serão usados intercambiavelmente neste texto, apenas por questões estilísticas.
} 
à teoria da gramaticalização, como é o caso da unidirecionalidade da evolução das formas lingüísticas. Então, pode-se formular o seguinte questionamento neste momento inicial da pesquisa: seria uma teoria da gramaticalização frágil no que se refere à validade de seu maior sustentáculo, o princípio da unidirecionalidade? Ou haveria no modelo brasileiro alguma diferença substancial de enfoque que justificaria as afirmações que o sustentam?

Para dar conta de responder a esses questionamentos, apresentaremos cada um dos modelos de análise e os princípios e métodos decorrentes da aplicação de cada um. Saber se partem de produtos lingüísticos ou de processos e que ferramentas são mobilizadas para a descrição lingüística é uma das preocupações deste trabalho.

No momento em que vislumbramos a possibilidade de dissertar sobre esse tema, já era considerado um consenso a idéia de que as constantes mudanças gramaticais são impulsionadas pela situação pragmática da língua em uso. Daí a relevância de se observarem dados tanto da modalidade oral (a mais dinâmica nas mudanças operadas) quanto da modalidade escrita formal e informal (as rédeas mais ou menos frouxas das alterações implementadas no dia-a-dia).

Muitos autores, dentre os quais citamos Halliday (1978 apud NEVES, 1997), desenvolvem análises da língua a partir e dentro do fato social. Isso se justifica na medida em que o funcionamento da língua se revela dentro da sociedade e serve para suprir as necessidades de comunicação de seu "usuário natural”. A lingüista brasileira Neves (1997:43-44) tece as seguintes considerações a esse respeito:

(...) a língua é o instrumento de interação social. Não existe, em si e por si, como uma estrutura arbitrária de alguma espécie, mas existe em virtude de seu uso para o propósito de interação entre seres humanos. (...) A principal função de uma língua natural é o estabelecimento de comunicação entre os usuários. Comunicação é um padrão interativo dinâmico de atividades através das quais 
os usuários efetuam certas mudanças na informação pragmática de seus parceiros.

Para a autora, a comunicação entre os falantes, usuários naturais da língua, é o ponto de partida para as várias significações das expressões lingüísticas. A busca de transformar essas significações em padrões ${ }^{2}$ para análise perpassa pelas modificações que são pertinentes a cada caso de produção.

Conforme a orientação funcionalista, identificar essas ocorrências de padrões distintos se faz necessário para que a análise se desenvolva em sintonia com o que de fato os falantes empregam em situações espontâneas de uso. A sistematização que daí decorre facilita o trabalho do investigador/analista da língua, que visa a recuperar o significado das expressões explicitadas pelo falante e a reconhecer os motivos que levaram à transformação.

Para verificarmos as diferenças de método, como já esclarecemos, será necessário lançar mão do estudo de um fenômeno ${ }^{3}$ inovador do português. Selecionamos por essa razão a palavra FORA em pleno processo de gramaticalização no português brasileiro. Observemos os seguintes exemplos:

(1) FORA advérbio: F: [ Acho que aqui FORA é melhor prá se trabalha] do que funcionário público, funcionário público tem que manda. Veja bem meu caso na área de educação (Peul- r-9)

(2) FORA preposição: E: Ah, é ? E faz muito tempo que você mora aqui em Campo Grande?

\footnotetext{
${ }^{2}$ O termo "padrão" e a expressão "padrão funcional" referem-se rótulos de uso comum na área da Gramaticalização e remetem aos usos empregados em situação real que podem ser quantificados em termos de types (freqüência por tipo de uso) e de tokens (freqüência da forma no texto, independentemente da função assumida).

${ }^{3}$ A comunicação entre usuários da língua faz com que esta sofra mudanças, então o termo 'fenômeno' aqui empregado se refere a uma palavra recorrentemente utilizada nos discursos (formais ou informais e falados ou escritos), com a finalidade de cumprir o objetivo de interação social.
} 
Faz, uns vinte anos.

E: Ah, é ? Ah... sim. É... você já morou em outros lugares ? (Est) FORA o Aterro onde você nasceu...

F: Irajá e Anchieta. (Peul-r-adri)

(3) FORA - interjeição: Em São Paulo, a maior cidade brasileira, o Grito dos Excluídos teve lugar diante do histórico Monumento da Independência, no bairro do Ipiranga. onde os manifestantes exclamaram os seguintes slogans: "Pátria livre é Pátria sem dívida" "FORA já, FORA já daqui o FHC e o FMI" e vaiaram os candidatos Maluf, Collor, Alckmin e Tuma. A candidata favorita nas pesquisas à prefeitura de São Paulo, a petista Marta Suplicy recebeu muitos aplausos da multidão. (http://www.verinha.de/grito_dos_excluidos.htm < acesso 2008/05/05>)

(4) FORA argumentativo: "Eu deveria ter nascido aí. Pois tirando a minha aparência (risos), gosto das mesmas coisas que vocês. Dançamos a mesma música, bebemos as mesmas bebidas, rimos das mesmas piadas. Esta será a minha única turnê no ano", diz o simpático inglês. "Decidi tocar porque amo o Brasil e os brasileiros. Eles parecem gostar de mim, também. FORA QUE ${ }^{4}$ o tempo na Inglaterra nesse período do ano é horrível”, justifica, gargalhando" (http://txt.jt.com.br/editorias/2007/01/26/var-1.94.12.20070126.1.1.xml)

Notemos que em cada um dos exemplos elencados, a palavra FORA assume uma função diversa. No exemplo (1), apresenta-se em seu uso mais lexical. Gradativamente vai se abstratizando e, já nos exemplos (3) e (4), encontramos um uso que não se pode propriamente encaixar na categoria adverbial. É um padrão funcional já gramaticalizado. Só esses exemplos já justificariam uma pesquisa sobre o item FORA.

Os exemplos (5) e (6) têm posição paradigmática fixa, formando no exemplo (5) uma expressão cristalizada "mundo ... AF $\boldsymbol{A} \boldsymbol{R} \boldsymbol{A}$ " e no exemplo (6) o dêitico já daria 
conta de comunicar, mas o item FORA é usado como eixo aí-lá, definindo o espaço físico em que o falante se encontra:

(5) F- Ah. Gostaria, sim. de viajar, ir à Europa, passear, não é? (est) Correr o-conhecer o mundo aí AFORA- isso no caso que o dinheiro desse.

E- A terra dos seus pais?

F- Também. Está aí. Também, (est) (Peul- c-11)

(6) F- Olha, brincava-se muito de roda e- aquele grupinho, não é? (Está) e <ti..>-podia brincar aí FORA à noite.

E: Você prefere mais sé profissional liberal... as diferenças entre..,[ profissional liberal e funcionário público?] (Peul-c-10)

Podemos fazer alusão à expressão FORA daqui que é recorrente em discursos, comumente em situações conflitantes. O estágio ainda incerto de mudança se dá a partir do reconhecimento de que a palavra FORA se apresenta normativamente classificada no conjunto das palavras invariáveis por trazer não necessitar de outras palavras para explicitar o seu significado, como afirmam um sem-número de gramáticos normativistas (CUNHA \& CINTRA 1985 e BECHARA 1999, dentre outros). Essa conceituação do item FORA permite que os gramáticos o insiram dentre itens da classe dos advérbios, entretanto, há uma grande distância entre casos identificados nas gramáticas e os usos apreensíveis em situações reais de uso, como demonstramos com exemplos de (1) a (6).

Justifica-se, então, a relevância de se focalizar esse item: analisando-o pelas expressões de fato empregadas pelos usuários, tem-se um quadro pragmático bastante ampliado de padrões funcionais. Num recorte sincrônico, como o apresentado nos exemplos, pode-se também exercitar uma leitura diacrônica.

\footnotetext{
${ }^{4} \mathrm{O}$ exemplo foi colhido do Jornal da Tarde, pois não foram encontrados exemplos no corpus do PEUL que se encaixassem na definição exposta.
} 
É nessa situação que se pode vislumbrar a dinamicidade da língua como um dos fatores de variação e mudança. Esses dois processos são interligados e podem ser descritos à luz da organização interna da língua no que a faz, ou seja, nos planos da gramática, semântica e pragmática.

Cada um dos padrões ilustra os usos reais assumindo um estatuto mais ou menos inovador face às prescrições gramaticais mais tradicionais e denuncia a polissemia de uma mesma forma lingüística da língua portuguesa do Brasil contemporânea.

Tendo em vista as características peculiares das amostras selecionadas para análise, a perspectiva funcionalista adotada e também a abordagem sincrônica, notamos uma aproximação necessária com alguns aspectos teóricos da Sociolingüística e da Gramaticalização, uma vez que admitimos, como Weinreich (apud MONTEIRO, 2000:57), que a língua, em situação de comunicação, revela-se tão complexa quanto a comunidade que a utiliza.

Para que se compreenda a trajetória inovadora da palavra sob análise, recorreremos ao resgate histórico do termo com base em informações de dicionários etimológicos e sincrônicos. Esperamos que esse encaminhamento permita reconhecer a rota de gramaticalização assumida desde o latim até o português do Brasil. Em busca de um diálogo com a normatividade, após as checagens de princípios e métodos de modelos teóricos, discutiremos a estigmatização e a incorporação de itens gramaticais à norma culta brasileira.

Esta dissertação, por conseguinte, encontra-se segmentada em quatro capítulos. O primeiro será reservado ao tratamento teórico da gramaticalização; o segundo se destina à apresentação de informações acerca das amostras que utilizamos para explanar o deslizamento funcional do item FORA e sobre o encaminhamento metodológico; no 
capítulo terceiro, ao estudo específico da palavra FORA; e, no capítulo quarto, aplicaremos cada modelo, objeto desta investigação, à checagem comparativa incluindo amostras dos mesmos falantes em contato e recontato. 


\section{Capítulo I}

\section{Fundamentação teórica}

\section{Definições de gramaticalização}

Iniciamos este capítulo da pesquisa enfocando os pressupostos de alguns estudiosos da gramaticalização. Elegemos aqueles que se preocuparam em oferecer definições sobre aspectos vinculados ao tema: Heine, Claudi \& Hünnemeyer (1991), Gonçalves, Lima-Hernandes \& Casseb-Galvão (2007), Neves (1997), Campbell \& Janda, (2001), Hopper \& Traugott (1993) dentre outros.

Com base nos textos desses autores, apresentaremos uma breve contextualização dos estudos feitos desde os trabalhos mais antigos até os mais atuais que permitem recuperar a trajetória de abrangência da gramaticalização; partiremos das idéias sobre a mudança lingüística determinada pelo esvaziamento de significado da palavra considerada plena ou lexical para a palavra com função gramatical. Para tanto, recuperamos informações sobre os estudos mais antigos relatados por Heine, Claudi \& Hünnemeyer (1991).

As observações mais antigas datam do século $\mathrm{X}$, em que os escritores chineses perceberam que existiam símbolos lingüísticos plenos e vazios. Na Dinastia Yuan, Zhou Bo-qi argumentou que os símbolos vazios teriam sido originários nos símbolos plenos, 
porém ainda não havia pesquisas desenvolvidas que tomassem esse um objeto de investigação.

Ainda Heine, Claudi e Hünnemeyer (1991) explicam que, séculos depois, na França, Condillac ${ }^{5}$ (1746) afirma que tanto a complexidade gramatical quanto o vocabulário abstrato são historicamente derivados de lexemas concretos. Quarenta anos depois, J. Horne Tooke (1786), agora segundo informações de Lehmann (1982, apud Neves, 1997:114), afirma que "o segredo das palavras reside em sua etimologia", ratificando as intuições mais recentes de que os valores surgem em decorrência de outros e de que traços etimológicos não seriam afetados pela mudança, o que permitiria estabelecer a relação histórica entre padrões funcionais.

$\mathrm{Na}$ Alemanha, Bopp (1816,1833) fez estudos histórico-comparativos e demonstrou que o desenvolvimento de materiais lexicais dá origem a auxiliares, estes a afixos, e estes últimos a morfemas gramaticais. Essa idéia foi também vislumbrada pelo alemão Humboldt (1822, apud NEVES, 1997:114) ao apresentar evidências de que a gramaticalização de preposições e de conjunções toma como ponto de partida itens que denotam objetos.

Gonçalves, Lima-Hernandes \& Casseb-Galvão (2007:18-19), resenhando trabalhos sobre gramaticalização, explicam que Antoine Meillet (1912) é, no ocidente, o mais difundido pesquisador sobre as mudanças atribuídas a palavras autônomas (lexicais) que passam a ter função de elemento gramatical. Ele também foi o primeiro a utilizar o rótulo gramaticalização (grammaticalisation). A seguir, há um fragmento da obra de Meillet em que ele define a gramaticalização:

\footnotetext{
${ }^{5}$ A gramaticalização, mesmo que ainda não determinada por esse nome, é analisada por Condillac (1746) ao explicar "as desinências pessoais do verbo pela aglutinação de pronomes pessoais. Outra análise é a do tempo verbal em coalescência de um advérbio temporal com o tema verbal”. (Neves, 1997:114)
} 
[Besides analogy,] another process consists in the change of an autonomous word into the role of a grammatical element...Th[is]...process, [involving] the attribution of grammatical character to a formerly independent word.... [, is one of] only [two] ways by means of which new grammatical constructs are formed. ${ }^{6}$ (MEILLET, 1912/1926 apud CAMPBELL \& JANDA, 2001).

Ainda Meillet (1912:133) afirma que a gramaticalização seria responsável pela modificação do sistema lingüístico não somente restrita a uma mudança morfológica da palavra, mas também às mudanças inconscientes promovidas pelo falante em decorrência do próprio vínculo social e cultural que a palavra carrega.

The 'grammaticalization' of certain words creates new forms, introduces categories that did not use to receive linguistic expression, [and] transforms the overall system' formed. ${ }^{7}$ (grifos nossos)

Campbell \& Janda (2001:95) citam Kurylowicz (1965/1975) com uma das definições mais recorrentes nos estudos atualmente:

Grammaticalization consists in the increase of a range of a morpheme advancing from a lexical to a grammatical or from a less grammatical to a more grammatical status. e.g. from a derivation[onal] ...formant to an inflectional one ${ }^{8}$.

\footnotetext{
${ }^{6}$ Nossa tradução: Além da analogia, outro processo consiste na mudança de uma palavra autônoma para a função (o papel) de um elemento gramatical. Esse processo envolve a atribuição de característica gramatical para uma palavra anteriormente independente é um dos dois únicos caminhos pelos quais as novas construções gramaticais são formadas.

${ }^{7}$ Nossa tradução: "a gramaticalização de certas palavras cria novas formas, introduz categorias que não costumavam receber expressão lingüística e transforma o sistema como um todo".

${ }^{8}$ Nossa tradução: "gramaticalização consiste no desenvolvimento de um morfema avançando de um estatuto mais lexical para mais gramatical ou de um menos gramatical para um mais gramatical; isto é, de um morfema derivacional para um morfema flexional".
} 
Notemos que há um caráter mais morfológico na definição. A despeito da abertura oferecida pela definição de Meillet, parece que ainda muitos estudos restringem suas observações sobre mudanças a explicações totalmente internas ao sistema lingüístico, dando eco à definição de Kurylowicz, que reserva a definição às mudanças operadas no continuum morfema derivacional $>$ morfema flexional.

De qualquer modo, é somente na segunda metade do século XX que as noções de gramaticalização deixam de ser ligadas apenas a um termo isolado e ganham maior abrangência.

Em Hopper \& Traugott (1993, p.xv, apud NEVES, 1997) gramaticalização envolve não somente a morfologia e a semântica. Envolve, também, sintaxe, etimologia e pragmática. Mais do que isso, envolve um conjunto de categorias cognitivas. Mais do que itens isolados, lidam com o estudo de porções oracionais e de processos de combinação de orações.

Isso só foi possível porque estudos anteriores, como o de Sweetser (1988), Heine Claudi \& Hünnemeyer (1991), Svorou (1993), dentre outros, observam a gramaticalização além da estrutura da língua, buscando uma relação entre o domínio cognitivo e o uso lingüístico.

Sweetser (1988) revela que quando inicia a trajetória da gramaticalização, o item perde um conteúdo semântico já existente e ganha outro; entretanto, Traugott e König (1991) explicam que não há perda de material semântico, e sim um aumento por meio de metáfora, metonímia e extensão.

Heine, Claudi e Hünnemeyer (1991) unem suas idéias às de Lakoff \& Johnson (1980) e argumentam que o ser humano traz em sua mente um sistema conceitual que se estrutura de forma metafórica; explicam que os primeiros conceitos que o humano tem 
são os de espaço (locativo) e de tempo. Após o desenvolvimento do componente locativo, tem-se a possibilidade da ampliação para o segundo que é o temporal e, conforme a maturidade de percepção se amplia, sucessivamente reconhecem-se outros mais abstratos.

Traugott (1989: 34-35) explica que os passos da mudança semântica possuem tendências, a que se adequa ao grupo exposto é a primeira, locativa, pois afirma serem os significados baseados na situação externa passam a ter significado interno, ou seja, o vocabulário do domínio externo (sociofísico) passa a ser interno, pelo domínio do emocional e psíquico.

Svorou (1993:02) afirma que a ligação entre o mundo físico e a linguagem perpassa por um nível conhecido como 'cognição'. Contudo, antes de avaliar um item analisável pela cognição, diz a autora que é necessário apreendê-lo pelas suas formas gramaticais, suas variações e pelas suas funções históricas de interação social.

Entendemos, assim, que para apreender a trajetória histórica de mudança lingüística, será necessário lidar com os vários subsistemas lingüísticos e, mais do que isso, tentar compreender por meio dos usos sincrônicos as várias camadas históricas de usos do item FORA.

\section{Mecanismos de mudança}

$\mathrm{Na}$ busca da [sic] comunicação mais eficaz e rápida, itens (palavras ou expressões lingüísticas) já conhecidos e sedimentados em seus conteúdos abrem espaço para serem revisitados com novos conteúdos e, conseqüentemente, com novas funções. 
Essa movimentação, que surge das expressões veiculadas pelos falantes nativos de uma língua não ocorre aleatoriamente, ela é impulsionada por esse princípio cognitivo específico de buscar em velhas formas novas funções.

Nesse sentido, afirma Heine (1991b: 150) que os conceitos concretos são utilizados para entender, explicar ou descrever os fenômenos menos concretos:

(...) clearly delineated and/or clearly structured entities are recruited to conceptualize less clearly delineated or structured entities, nonphysical experiences are understood in terms of physical experiences, time in terms of space, cause in terms of time, or abstract relations in terms of kinetic process or spatial relations, etc ${ }^{9}$.

Heine, Claudi \& Hünnemeyer (1991a) explicam que, para ocorrer essas transferências conceptuais, entramos em domínios cognitivos diferentes (metáfora); quando há a motivação pragmática (pelo uso da expressão), a transferência conceptual é a reinterpretação da expressão usada pelo contexto em que ela está inserida (metonímia).

Sweetser (1990), Bybee, Perkins \& Pagliuca (1994), Heine \& Reh (1984), Heine, Claudi \& Hünnemeyer (1991a) são alguns dos autores que confirmam que a mudança semântica da expressão lingüística, no processo de gramaticalização, tem como fatores propulsores os processos metafóricos.

Sweetser (1990) explica que a linguagem é fundamentada nas habilidades cognitivas humanas, dentre elas, a percepção e interação que estão profundamente envolvidas na determinação de categorias lexicais. Ela afirma, portanto, como fizera Meillet, que a estrutura interna do significado das palavras depende do contexto (não é

\footnotetext{
${ }^{9}$ Nossa tradução: (...) estruturas claramente delineadas e/ou entidades claramente estruturais são recrutadas para conceituar as entidades menos claramente delineadas, experiências não físicas são entendidas em termos de experiências físicas, tempo em termos de espaço, causa em termos de tempo, ou relações abstratas em termos de processos sinestésicos ou relações espaciais.
} 
autônoma) e é baseada em protótipos. A linguagem, assim como a cognição, opera na mente de forma metafórica, como uma fonte de elos entre os múltiplos sentidos de uma palavra.

Somente examinando o mapeamento metafórico envolvido no tratamento lingüístico e cognitivo dos estados mentais e dos atos de fala, poderemos entender por que determinadas categorias de palavras refletem desde o estado físico, ao de movimento ou ao mental, numa dinamicidade que produz derivação. Todas as palavras que circulam entre as categorias podem ser fontes para certas áreas abstratas de significado com outros significados mais abstratos ainda.

O processo metafórico é entendido como a abstratização crescente, portanto é um processo unidirecional. Nesse sentido, conceitos mais próximos da experiência humana são utilizados para expressar o que é mais abstrato. Heine, Claudi \& Hünnemeyer (1991) explicitam que esse mecanismo tende a marcar do espaço para o discurso (espaço>discurso), como podemos verificar com a palavra FORA nos exemplos apresentados anteriormente: de uma marcação espacial (física e mais concreta) derivam-se valores mais abstratos, como é o caso da expressão FORA daqui, com função de organização argumentativa.

O mundo físico funciona como organizador do universo abstrato. Como visto anteriormente, esse mecanismo é mais relevante quando há regularidade de utilização de expressões que indicam espaço ou tempo para marcar pontos específicos no texto, ele é marcado no texto como espaço físico $>$ discurso.

A metonímia, cuja manifestação depende do encadeamento sintático, é entendida como um processo criativo bastante produtivo nas línguas. É o que observam Heine, Claudi \& Hünnemeyer (1991: 61): We may define metonymy as a figure of 
speech whereby the name of an entity is used to refer to another entity that is contiguous in some way to the former entity ${ }^{10}$.

Para que opere, a metonímia depende de reanálise sintática e seu gatilho é a pressão de informatividade, como afirmam Traugott e König (1991). Sendo uma mudança na estrutura de uma expressão, nem sempre se nota uma mudança na superfície dessa expressão, ou seja, é como a fusão de dois ou mais elementos que, ao formarem uma única expressão, não se denota sua mescla, mesmo que ela seja explícita e/ou mudança de fronteira sintática formada por justaposição. Invariavelmente, está envolvida na mudança gerada por metonímia.

Durante o processamento das informações em situações comunicativas, a pressão pela relevância e informatividade (TRAUGOTT \& KÖNIG, 1991) atua de modo a gerar novos operadores argumentativos, motivados pela situação de conversação, tal como verificamos com a palavra FORA no exemplo seguinte:

(7) Há tempo venho falando que o SPFC neste ano (FORA um ou dois jogos) não vem correspondendo com um bom futebol. Isso até certo ponto é normal pois perdemos peças fundamentais de conquistas recentes, como Danilo, Mineiro e Fabão.” http://www.saopaulofc.com.br/articles.php?id=576

Essa discussão tecida sobre "gramaticalização" permite concordar com LimaHernandes (2005), que afirmou não ser possível apreender o processo dinâmico da gramaticalização sem se levar em conta as relações estabelecidas em torno da estrutura associadas à atividade cognitiva subjacente.

\footnotetext{
${ }^{10}$ Tradução nossa: Podemos definir metonímia como uma figura de linguagem com a qual o nome de uma entidade é usado para se referir a outra entidade que é contígua de algum modo à forma inicial.
} 
Ainda que ambigüidades possam ocorrer e sejam, em alguns casos, obstáculos para a comunicação eficaz, estas desencadeiam reanálise e analogia ${ }^{11}$ que redundam em paradigmatização da nova forma. Dessa acomodação, surte o efeito da intercompreensão nas futuras situações comunicativas empreendidas por falantes de uma comunidade.

Dessa forma, mesmo a ambigüidade, vista por muitos como um fenômeno indesejável na comunicação, funcionaria como uma mola propulsora da mudança, um gatilho da reanálise e da analogia e, por conseguinte, importante elemento para a movimentação do sistema lingüístico.

\section{Abordagens sincrônica e diacrônica}

Uma dúvida comum entre os iniciantes nos estudos sobre gramaticalização refere-se à abordagem ideal. A resposta a essa dúvida implica o método adotado e os objetivos a serem atingidos com um estudo.

Kuhn (1962 apud NEVES, 1997) orientava que a descrição lingüística deveria ser sincrônica; que a arbitrariedade entre forma e sentido prejudicaria toda a interpretação que não se baseasse em dados sincrônicos. Subjazia a essa orientação a idéia de que forma e sentido mantinham uma relação de biunivocidade. Se acrescentarmos a essa idéia a noção de contexto de uso, talvez pudéssemos concordar totalmente com o que Kuhn defendia.

\footnotetext{
${ }^{11}$ São motivações para a mudança lingüística, a analogia é um processo que empregamos para observar as mudanças no eixo paradigmático em que se faz uso de formas preexistentes (regras) sobrepondo-se a construções já existentes no sistema, mas com inovações no eixo paradigmático. Já o eixo sintagmático tem a mudança observada sob o nome de reanálise que permite a criação de nova formas gramaticais, "alterando as fronteiras de constituintes em uma expressão, levando uma forma a ser reanalisada como pertencente a uma categoria diferente da original" ( GONÇALVES; LIMA-HERNANDES \& CASSEBGALVÃO, 2007:50)
} 
Na concepção diacrônica, temos Mattisoff (1991, apud CAMPBELL \& JANDA, 2001), que analisa a gramaticalização como um processo da semântica histórica, pois o termo traz o 'morfema-radical (raiz)' com um significado lexical que assume um significado de abstrato funcional ou mais gramatical.

Mesmo que não se possa lançar mão de uma amostra de dados diacrônicos confiável, ainda há o recurso de se cotejarem materiais lexicográficos de épocas variadas. Além disso, há o sempre disponível recurso etimológico, que permite recuperar, se não o traço etimológico vital, ainda elementos que o revelem em combinação com os vários usos sincrônicos.

Se se pode efetivar uma abordagem histórica, que visa ao estudo etimológico e das mudanças sucessivas de itens nas línguas, na perspectiva sincrônica, identificam-se os padrões fluidos de uso. São abordagens que se completam, é verdade. Contudo, não é imprescindível que o pesquisador faça a combinação de abordagens para que alcance resultados interessantes no que tange ao processo de mudança por gramaticalização.

Tanto se pode partir da sincronia e verificar os vários usos reais que se manifestam na sociedade, certamente acumulados durante seu desenvolvimento histórico, quanto se pode priorizar o levantamento de dados históricos e, a partir das recorrências século a século, verificar as sucessivas recategorizações funcionais.

Neste estudo, propomos uma combinação da abordagem diacrônica, ensaiada por meio da consulta a dicionários de várias épocas e a dicionários etimológicos, a uma abordagem sincrônica, calcada na descrição dos padrões fluidos de uso. Dessa forma, cremos contribuir para a construção de uma linha imaginária de desenvolvimento histórico de um item que inicia sua trajetória como um locativo (categoria cognitiva mais básica ao indivíduo) e assume uma rota de abstratização contínua no português do Brasil. 
Portanto, este estudo envolverá aspectos diacrônicos sem, necessariamente, lidar com a diacronia documental, uma vez que essa estratégia permitirá observar a evolução do advérbio FORA a partir de um continuum em que estejam representados deslizamentos funcionais operados.

\section{Princípios da gramaticalização}

Uma das características mais estudadas da gramaticalização é justamente o caminho que esse processo percorre, demonstrado invariavelmente por meio de um continuum. Nesse sentido, tem sido aceito pela maioria dos pesquisadores de gramaticalização que a unidirecionalidade é um fato.

Heine (2003) explica que a gramaticalização de uma expressão lingüística mescla quatro processos:

(i) Dessemantização (bleaching, redução semântica) - perda de conteúdo semântico.

(ii) Extensão (ou generalização de contextos) - uso em novos contextos.

(iii) Decategorização - perda de propriedades características das formas-fonte, incluindo perda de status de forma independente (cliticização, afixação).

(iv) Erosão (ou redução fonética) - perda de substância fonética.

Esses processos propulsionam três estágios (overlap model), conforme expõe Lima-Hernandes (2005), com base nas idéias de Heine (2003):

(i) Há uma expressão lingüística A, que é recrutada para sofrer gramaticalização. 
(ii) Essa expressão adquire um segundo padrão de uso, B, que apresenta ambigüidade em relação a $\mathrm{A}$.

(iii) Finalmente A se perde, e somente B aparece como uso possível.

Os casos de 'forte' gramaticalização chegam ao terceiro estágio, mas os que estão em quaisquer patamares dos estágios acima expostos, já estão no processo de gramaticalização.

Com relação aos efeitos desse processo de gramaticalização, podem ser identificados os seguintes, conforme apresenta Neves (1997:121):

- precedência do desvio funcional (conceptual ou semântico), sobre a formal (morfossintático e fonológico);

- decategorização de categorias lexicais prototípicas;

- possibilidade de recategorização, com restabelecimento da iconicidade entre forma e significado;

- perda de autonomia de um elemento (uma palavra autônoma passa a clítica, um clítico passa afixo);

- erosão ou enfraquecimento formal.

Um dos exemplos propostos por Hopper \& Traugott (1993:7 apud NEVES, 1997:121) especifica uma escala para a unidirecionalidade da gramaticalização, a saber: item de significado pleno $>$ palavra gramatical $>$ clítico $>$ afixo flexional.

A unidirecionalidade tem sido, como afirmamos anteriormente, aceita como princípio pela maioria dos trabalhos sobre gramaticalização. É o que vemos em 
Lehmann (1982), Hopper (1991) e Heine, Claudi \& Hünnemeyer (1991). Não é, entretanto, o que ocorre com Castilho (2003) que funda essa oposição ao princípio legítimo da gramaticalização em conceitos relativos à língua e à gramática.

O autor apresenta um resumo de como outros estudiosos entendem a língua “(...) uma entidade heteróclita, estática, passível de representação através de uma linha, na qual podemos reconhecer pontos e estabelecer derivações entre esses pontos." (CASTILHO, 2003:12); continua sua linha de raciocínio explicando-se em três pontos, que aqui reproduzimos, intercalados por nossos comentários:

(1) As línguas naturais são um conjunto de signos dispostos numa linha. A alteração desses signos se dá por estágios unidirecionais, de tal maneira que a um estágio A se segue um estágio $\mathrm{B}$, a este se segue um estágio C, e assim por diante: Hopper / Traugott (1993: 95). Cada estágio corresponde a um ponto na língua-linha, e, portanto, uma relação de seqüencialidade pode ser estabelecida entre esses pontos. Em estudo recente, Mattos e Silva (2002) evidenciou a vertente neogramatical desta perspectiva, em suas pesquisas sobre as "leis fonéticas". Como se sabe, foi o "neogramático" Antoine Meillet quem deu visibilidade ao problema da gramaticalização, em seu estudo sobre as conjunções. A teoria lingüística dos neogramáticos foi conservada nos estudos contemporâneos sobre esse processo. (CASTILHO, 2003:12);

O autor faz uma série de questionamentos a respeito da linha imaginária a partir da qual o sistema da língua se desenvolve, além da compartimentalização das categorias gramaticais, até então não questionada. Elabora algumas perguntas que conduzem o leitor à aceitação de uma nova visão de Gramaticalização integrante da Teoria Multissistêmica: 
(2) Depositadas sobre essa linha, categorias lexicais dão surgimento a categorias gramaticais, e estas a categorias ainda mais gramaticais, entendendo-se por isto os afixos. Quereria isto dizer que os itens lexicais não têm propriedades gramaticais, suficientes para arranjálos em categorias próprias? Se eles não têm essas propriedades, como entender que as palavras possam ser dispostas nitidamente em classes lexicais, as conhecidas classes maiores (Pronomes, Nomes e Verbos), intermediárias (Advérbios, Adjetivos), e menores (Artigos, Conjunções e Preposições) que freqüentam estas páginas? Por outro lado, teriam essas classes um estatuto categorial claramente configurado, a ponto de se sucederem perceptivelmente umas às outras na língua-linha, permitindo-nos testemunhar sua metamorfose? Nesse caso, e pensando nos estudos funcionalistas sobre a gramaticalização, onde foi parar a Teoria dos Protótipos? Seriam mesmo tão claros os limites entre as classes lexicais, de tal forma que pudéssemos estabelecer uma relação de derivação entre elas? (id. p.13)

O entrelaçamento dos pontos anteriores ao último foi feito com o intuito de explicar que a gramaticalização não deve ser colocada na mesma linha imaginária que os fenômenos a ela inerentes. Segundo o autor, se isso ocorre, então não se pode falar em gramaticalização como uma teoria:

(3) Finalmente, na literatura sobre gramaticalização ficam situados no mesmo nível fenômenos tais como erosão fonética, descategorização /recategorização morfológica, ampliação dos empregos sintáticos, perda semântica, sem falar nas pressões do Discurso sobre o sistema. Esse ponto de vista levou diversos autores a dispor o Discurso, a Gramática e a Semântica num “(c)line” - e aqui faço um jogo de palavras associando line e cline - admitindo implicitamente uma hierarquia e uma decorrente derivação entre eles. Essa percepção implica em que no momento da criação lingüística nossa mente funcionaria por impulsos seqüenciais, isolados uns de outros, indo linearmente de uma classe lexical para outra, de um subsistema lingüístico para outro. (grifo nosso) (id., p.13) 
Em resumo, Castilho contraria os pressupostos da teoria clássica da gramaticalização, que, segundo ele, admite a língua como um processo, mas a utiliza como os produtos "prontos e acabados". No entanto, Castilho admite a língua como processo mental e lida com os mesmos produtos prontos e acabados.

Assim, diversamente do que Castilho (2003) explica, acreditamos que sua oposição remeta à concepção de língua como um “sistema pré-verbal”, portanto, mental. Desta forma, cremos que o autor está preocupado com o processamento cognitivo a partir de uma língua-processo, ainda que analise a língua-produto.

Sua argumentação a respeito da multidirecionalidade tem amparo científico nos avanços alcançados pelas ciências que lidam com estudos neurológicos. Se durante o processamento comunicativo, várias correntes elétricas (sinapses) são deflagradas em direções também diversas pela mente, então, pode-se compreender a recusa do autor em assumir uma unidirecionalidade derivativa.

Essas idéias, contudo, não implicam a desconstrução da teoria clássica da gramaticalização, que prioriza uma língua-produto, explanada em seus correlatos gramaticais (morfologia, fonologia e léxico), discursivo-pragmáticos por meio da codificação sintática, apreenderia o processo de elaboração do usuário da língua.

É justamente em consonância com esse princípio de unidirecionalidade a partir de uma língua-produto que procederemos, no capítulo seguinte, à organização dos padrões funcionais da palavra FORA. 


\section{Capítulo II}

\section{Aspectos Metodológicos}

\section{As amostras de língua portuguesa}

Como fonte de recolha de dados, elegemos um corpus constituído a partir das seguintes amostras: língua falada por cariocas em situação de entrevista oriunda do Projeto PEUL (Projeto de Estudos e Usos Lingüísticos), língua escrita em forma de textos midiáticos recolhida na internet (sites, blogs e orkuts) e língua formal escrita para fins acadêmicos (dissertações de mestrado).

$\mathrm{Na}$ amostra PEUL, como forma de ter uma representação bastante abrangente de falantes brasileiros que utilizam o dialeto carioca, coligimos entrevistas de cariocas com características diastráticas nem sempre coincidentes. Para dar abrangência também na linha do tempo, pudemos contar com a amostra de recontato do Peul, que se refere ao registro de gravações de entrevistas com os mesmos falantes gravados vinte anos antes na amostra contato. A seguir, apresentamos amostras das entrevistas de contato e de recontato. Observe-se que não há evolução escolar vinte anos depois:

Quadro 1 - Informantes PEUL - contato e recontato.

\begin{tabular}{|c|c|c|c|c|c|c|c|}
\hline \multicolumn{4}{|c|}{ Amostra 1980} & \multicolumn{4}{c|}{ Amostra 2000} \\
\hline Informante & Sexo & Data & Idade & $\begin{array}{c}\text { Escolari- } \\
\text { dade }\end{array}$ & intervalo & idade & $\begin{array}{c}\text { Escolari- } \\
\text { dade }\end{array}$ \\
\hline \multirow{2}{*}{ Jan } & M & 1999 & 56 & $\begin{array}{c}\text { Fundamental } \\
\text { 1- incompleto }\end{array}$ & 19 anos & 75 & $\begin{array}{c}\text { Fundamental- } \\
1\end{array}$ \\
\hline
\end{tabular}




\begin{tabular}{|c|l|c|c|c|c|c|c|}
\hline Jup & F & 1999 & 18 & $\begin{array}{c}\text { Fundamental } \\
\text { 1-incompleto }\end{array}$ & 18 anos & 36 & $\begin{array}{c}\text { Fundamental- } \\
1\end{array}$ \\
\hline Lei & F & 1999 & 25 & $\begin{array}{c}\text { Fundamental } \\
\text { 2-incompleto }\end{array}$ & 19 anos & 44 & $\begin{array}{c}\text { Fundamental } \\
\text { 2- incompleto }\end{array}$ \\
\hline
\end{tabular}

A escolha dessa amostra se explica não somente pela facilidade de acesso ao material já digitalizado, mas principalmente pela forma de sua constituição à época dos registros. Houve, naquele momento, a preocupação com o método de condução das entrevistas, que são semicontroladas, favorecendo uma fala mais frouxa e menos presa à normatividade. No recontato, manteve-se a mesma estratégia e mesmo tema para a interação.

Para justificarmos as modalidades de uso da língua que utilizaremos nas amostras, faz-se necessário discernir cada uma delas dentro do meio social. Marcuschi (2007:35) explica que as modalidades refletem:

a organização da sociedade. Isso porque a própria língua mantém complexas relações com as representações e as formações sociais. (...) a fala não apresenta propriedades intrínsecas negativas, também a escrita não tem propriedades intrínsecas privilegiadas. São modos de representação cognitiva e que se revelam em práticas específicas. (...)

Ainda o autor explica que, diante de uma postura ideológica, a escrita se sobressai à fala na sociedade. Em relação aos usos quotidianos da língua, continua Marcuschi (2007:36), “constatamos que a oralidade e a escrita não são responsáveis por domínios estanques e dicotômicos. Há práticas sociais mediadas preferencialmente pela escrita e outras pela tradição oral".

Outro aspecto que o autor aponta é que a escrita é vista como "algo naturalmente claro e definido. (...) um fenômeno se não homogêneo, pelo menos bastante estável e com pouca variação" (2007:37); já a fala se mostra variada e, quando 
a usamos, não lançamos mão da fala padrão, dada sua espontaneidade. Portanto, são modalidades não competitivas que surgem no domínio "tipológico das práticas sociais de produção textual e não na relação dicotômica de dois pólos opostos” (2007:37).

Ainda baseando-nos no texto de Marcuschi (2007:41), há 'o gráfico de representação do contínuo dos gêneros textuais na fala e na escrita', que parafraseamos para justificar nossa escolha de modalidade e gênero para a composição do corpus, nele o autor separa as modalidades desde a mais espontânea até a mais padronizada.

$\mathrm{Na}$ escrita, têm-se as comunicações pessoais (cartas pessoais, bilhetes) e outras não tão pessoais, como é o caso de outdoors e inscrições em paredes e avisos. Em pólo mais distante estão as comunicações públicas (notícias de jornal, cartas de leitor, formulários, entrevistas e volantes de rua). Pode-se, ainda, distinguir textos em instrucionais (textos publicitários, cartas comerciais, narrativas, telegramas, atas de reuniões). Os gêneros de comunicações públicas e o de textos instrucionais têm em comum as convocações, comunicados e anúncios. Os textos acadêmicos compartilhariam com os textos instrucionais os seguintes gêneros: divulgação científica, textos profissionais, editoriais de jornais, manuais escolares, resumos, instruções de uso, bulas, receitas em geral. Como se pode notar, configura-se uma teia de gêneros compartilhados, tendo em vista a origem da produção comunicativa.

Especificamente, o texto acadêmico foi escolhido como um dos núcleos deste estudo e está no topo da modalidade escrita mais formal, justamente por ser produzido numa área de tradição com o cuidado com a expressão da língua materna, qual seja, a produção científica do mestrado das Letras Clássicas e Vernáculas e de Filologia e Língua Portuguesa, mais especificamente as dissertações de mestrado, evidenciando o protótipo dessa modalidade em seu mais alto grau de formalidade. Ao lado desse tipo de 
texto, há os artigos científicos, leis, documentos oficiais, relatórios oficiais, relatórios técnicos e pareceres em processos.

A modalidade falada também se dissemina em graus de formalidade. O material, contudo, utilizado para esta pesquisa se perfaz por meio do gênero mais espontâneo, o das conversações, da conversa espontânea, que poderia se formalizar ou perder em informalidade se ligada ao gênero de conversa telefônica e de conversas públicas. As entrevistas podem aparecer revestidas de gêneros diversos, tais como discussões no rádio e na $\mathrm{TV}$, debates, inquéritos, entrevistas no rádio/TV, entrevistas pessoais, reportagens ao vivo, inquéritos e discursos festivos; esse gênero aproxima-se, em algumas de suas propriedades, da oralidade apresentada em noticiários de rádio, noticiários de TV e explicações técnicas.

Outra peculiaridade reforça a distância entre entrevistas e materiais oriundos da academia: o caráter oficial desses pronunciamentos. As exposições acadêmicas, tais como conferências e palestras ou aulas configuram o protótipo dos discursos oficiais.

Ainda buscando a abrangência de usos do português, procedemos à compilação de amostras a partir da consulta a blogs e a orkuts. Esse gênero é observado por Marcuschi (2002) como oriundo da modalidade de escrita agregado às estratégias da modalidade da fala. Podemos inferir que há, principalmente nos blogs, as mesmas características encontradas na conversação em chat (SILVA, 2008:195) “com uma linguagem escrita não-monitorada", ou seja, não-submetida a revisões, expurgos ou correções. É uma linguagem em seu estado natural de produção.

Ainda Silva (2008), concordando com Marcuschi (2002), afirma com relação ao hibridismo entre fala e escrita no meio virtual que muito provavelmente há produções em que não se pode notar mais a distância entre as modalidades falada e escrita. 
A representação do contínuo dos gêneros textuais nas modalidades de fala e de escrita apresentada por Marcuschi (2007) segmenta em dois pólos opostos as conversações e as exposições acadêmicas, núcleos de nosso corpus, assim como o midiático $^{12}$ : conversações - entrevistas - apresentações e reportagens - exposições acadêmicas.

Em suma, há três núcleos que constituem o corpus desta pesquisa que podem ser diferenciados quanto à espontaneidade: a conversação gravada (entrevistas do PEUL) como a mais espontânea e os sites, blogs e orkuts, com possibilidade de maior controle sobre a produção. Em relação à escrita, optamos pelo extremo oposto, constante do gráfico de Marcuschi (2007:41) em que os textos acadêmicos são alocados num pólo de maior padronização. Para a análise constituímos uma amostra com algumas dissertações de mestrado (especificamente da área de Filologia e Língua Portuguesa), dado seu caráter mais formal.

\section{Dissertações que constituíram a amostra}

GOH, Simone Strelciunas - Metalinguagem e marcas de oralidade em Monteiro Lobato Dissertação. São Paulo, 2004.

MASSI, Maria Lúcia Gili. Deméter : a repulsão medida. Dissertação, São Paulo 2001.

MODESTO, Artarxerxes Tiago Tácito. Formas de tratamento no português brasileiro : a alternância tu/você na cidade de Santos-SP. São Paulo, 2006

ANJOS, Eliane Dantas dos. Glossário terminológico ilustrado de movimentos e golpes da capoeira : um estudo término-lingüístico. São Paulo, 2003.

\section{Materiais virtuais que constituíram a amostra}

http://www.saopaulofc.com.br/articles.php?id=576

http://www.carlosbranco.jor.br/jijicap01.html

http://www.focografico.weblogger.terra.com.bi720Q406_fbcografico_arqurvo.htm

\footnotetext{
12 Os textos midiáticos, como já explicados, não constam no contínuo proposto por Marcuschi (2007), mas foi explicado pelo mesmo autor em texto de (2002) e por Silva (2008).
} 
http://videochat.globo.com/GVC/arqinvo/O..GO6244-3362.00.html

http://ciscocosta.com/fílisteu/?cat=34

http://foradecasa.blogger.com.br/

http://orbita.starmidia.com/frasez/seuemail.htm

http://br.answers.yahoo.com/question/index?qid=20070423194405AAp6RUx

http://www.gente.ig.com.br/materias/2008/01/01/jared_leto_leva_um_for...os_em_festa 1136055.html

http://www.verinha.de/grito_dos_excluidos.htm

Essas escolhas foram feitas porque buscamos sistematizar, ou pelo menos compreender, a possível rota de gramaticalização do advérbio FORA em contextos usuais na língua portuguesa, mesmo que para essa análise, tenhamos nos atido no falar carioca inicialmente, contudo, sempre observamos a forma de desenvolvimento da comunicação em outras fontes, que não apenas a do PEUL, portanto de uma forma mais abrangente representada pelas modalidades falada e escrita.

Reunido o material em que aparecia o item fora, computamos mais de 200 ocorrências, a partir das quais identificamos 11 padrões funcionais que, pela proximidade de formação e de função, devem representar o desenvolvimento histórico da palavra FORA no português do Brasil.

\section{As perguntas e as hipóteses}

Toda proposição de trabalho científico inicia-se com a formulação de perguntas e com a intuição acerca dos resultados que se espera encontrar num momento posterior.

Numa incursão inicial pelos dados reunidos já se elaboram questões que se tornam metas do trabalho de pesquisa. Assim, a partir de dados oriundos das amostras já apresentadas de língua portuguesa escrita e falada, em situações de uso formais e 
informais, julgamos possível responder a perguntas que emergem da aplicação de cada um dos modelos.

A fim de refazer o percurso metodológico da pesquisa, apresentamos as perguntas que elaboramos inicialmente sobre o fato:

1. sendo invariável, como o advérbio poderá ser admitido em outra classe gramatical sem prejuízo de sua forma e adquirindo nova função?

2. Seriam todos os deslizamentos funcionais operados resultantes do processo de gramaticalização?

3.os continua a que essas alterações remetem podem ser depreendidos de usos da modalidade falada?

4. a que tipo de categoria remete a unidirecionalidade da mudança? Seriam as categorias cognitivas subjacentes sensíveis à unidirecionalidade da mudança?

Essas questões serão respondidas no decorrer da análise dos dados no capítulo seguinte, entretanto, algumas hipóteses podem ser aventadas:

1. pelo que se conhece da história dos advérbios nas línguas em geral, sabe-se que advérbios dão origem a conjunções.

2. Se todos os deslizamentos seguirem uma rota de abstratização e recategorização poderão ser explicáveis pelo processo de gramaticalização; se, contudo, alguns deslizamentos funcionais evidenciarem uma ressemantização tal que culmine com a criação de um item menos gramatical, então poderão ser explicáveis por um processo de lexicalização.

3. a modalidade falada é a instância das grandes inovações gramaticais, portanto, deverá ser também o locus da maior recorrência das recategorizações. 
4. a unidirecionalidade pode ter correlatos gramaticais fortes e ser evidenciada pela recategorização, portanto por uma organização unilinear de classes morfológicas; pode, contudo, demonstrar-se um processo complexo que demande a busca de correlatos menos visíveis, como é o caso das categorias cognitivas.

A fim de responder às indagações e confirmar nossas hipóteses, inicialmente assumimos que a pesquisa etimológica seja uma necessidade premente, haja vista que lexicógrafos diferentes poderão aventar caminhos diferentes para o desenvolvimento do item fora no português. Em segundo plano, julgamos pertinente a análise mais detida de gramáticas para o entendimento do que normativamente é afirmado sobre o item analisado. Consideramos também que, num terceiro plano, devamos recorrer à identificação dos padrões funcionais, depreendidos das várias ocorrências do item fora, os quais fornecerão pistas para o desenho de um continuum de deslizamento na rota de gramaticalização. 


\section{Capítulo III}

\section{A palavra FORA no Português do Brasil}

Este capítulo foi imaginado inicialmente para a resenha crítica da produção de vários estudiosos que tivessem se detido no estudo do advérbio FORA. Num rastreamento bibliográfico bastante amplo, contudo, notamos que esse advérbio não foi priorizado como tema de estudos.

Assim, partimos para o reconhecimento da etimologia dessa palavra, bem como dos vários sentidos que foi assumindo historicamente no português. Também procedemos a uma incursão em gramáticas normativas e descritivas, já que nos interessa, sobremaneira, verificar a evolução dos estudos sobre a categorização do item sob análise.

\section{Etimologia da palavra FORA e seus deslizamentos funcionais}

Esclareceremos que, diferentemente do que imaginávamos de início, a palavra FORA tem sua gênese "filiada ao acusativo plural da raiz indo-européia porta", como afirma Viaro (1994:205). E essa noção é ratificada pelo mesmo autor, já em 2003, quando especifica que na CVA (construção de verbo + advérbio) há imagens associadas aos advérbios de lugar, e que elas denunciam: 
(...) os rumos percorridos por um decalque pode chegar a abalar a visão simplista de sistema lingüístico. Não é por acaso que palavras como a do grego ekkleío, o latim excludo, o alemão ausschließen, norueguês utelukke, russo izkljuchit', húngaro kizár significam "excluir" e são compostas de um prefixo que significa "para FORA" e de um radical que significa "chave". Se, por um lado, é facilmente derivável a idéia de que excluir é deixar alguém trancado do lado de FORA, essa noção não pode ser considerada universal (só seria desenvolvida em comunidades cujas casas têm portas, que, por sua vez, são trancadas a chave) nem lógica (pois depende de entes materiais cuja invenção advém da necessidade e arbítrio de uma comunidade). (VIARO, 2003:175-176)

Deve-se notar que a palavra chave é colocada com um dos radicais que determinam a palavra excluir nas línguas já citadas; daí a necessidade de saber a origem da primeira; no dicionário Houaiss, na nona acepção da derivação, temos por extensão de sentido: "qualquer instrumento ou ferramenta capaz de abrir ou fechar, apertar ou afrouxar, fixar, acionar, regular etc. um mecanismo dotado de parafusos, porcas, molas etc." Nossos grifos salientam que esse instrumento (chave) é útil ao abrir ou fechar, então, por analogia, temos a idéia de que a porta pode se encaixar como um dos objetos ao qual o instrumento (chave) seja necessário.

Na obra de 1994, o autor afirma que esse item também ocorre no balto-eslavo, germânico, sânscrito, grego, céltico e armênio. Só depois é que surge no latim tardio como preposição, visto na forma acusativa ou genitiva: FORA é tido como " $a$ foras, $a$ foris, de foras, de foris.(...) port. FORA e combinações de FORA de, para FORA de, por FORA de, AFORA". Portanto, a trajetória histórica da palavra tem como ponto de partida um objeto concreto: porta. 
Perguntamo-nos, nesse momento da pesquisa, quais seriam as motivações para que um item adverbial denotador do espaço locativo externo em relação a outro, considerado interno, pudesse ter derivado do nome porta. Hipotetizamos que, em sendo porta um elemento concreto, delimitador do espaço físico externo/interno, não seria difícil que, por um mecanismo de extensão metafórica, pudesse ter sido revestido da nova significação. Julgamos, então, procedente uma pesquisa cronológica das acepções da palavra em dicionários diversos ${ }^{13}$.

No Dicionário de Raphael Bluteau (1713: 165-166), os significados da palavra FORA são referendados por citações de autores (pensadores) latinos, como Cícero, Plautus e Plinius, entre outros. Bluteau se refere ao item 'FORA' como um advérbio relativo de lugar, oposto a dentro:

1-FORA de casa (quando não há movimento) Se eu estou em casa, estou fóra com o espírito. (Si domi fum, foris est animus) Plaut. (quando há movimento)

2-FORAS. advérb. Lançar FORA alguma cousa. Aliquid FORAs projicere. (Cic) Lançou o FORA. Exclusit eum FORAs. (Terent.).

3- Sahir fóra. Exire FORA. (Plaut); Por fóra. Forinfecus. Columpl. Plin. Hist. Extrinfecus. Cic. Sahir fóra. Exire FORA. Plaut.

4- Fóra da cidade. Extra urbem (Cic.)

5-Fóra de perigo. Extra periculum (Cic.) Elle vem de fóra. Forisadvemt.

6-Vay para fóra. FORAs abit.

7-Fóra. Fóra daqui (quando se diz a alguém, que se vá).

8-FORA de si.

9-FORA de propósito.

10-Cousa, que vem de FORA, que se traz de FORA, que não nasce no reyno, como certas mercãcias, que nos vem por mãos de

\footnotetext{
${ }^{13}$ A numeração e nova diagramação das acepções dicionarizadas foram necessárias para o melhor entendimento da comparação entre os dicionários.
} 
estrangeiro. 11-Deixa de FORA. Não pôr no numero. Não fazer menção.

12-De FORA, ou por FORA. Pela parte exterior.

13-FORA. Contra. Não teria FORA de razão ocrer, que isso succedeo deita FORA.

14-FORA. Além. Vid. No seu fugar. FORA. He usado em muytos outros modos de fallar.

15- Das portas a FORA. Guia de casador. 51. vers. Que lhe não imputassem tribuotos FORA daquelles, que, se costumavaõ.

A fim de compreender a ligação do universo físico para o mental, aventamos a idéia de que o FORA deva ter iniciado seu processo de concepção por falantes nativos, a partir da antiguidade. No fragmento da obra de Bluteau (1713), observemos a referendação oriunda de Plautus: "Se eu estou em casa, estou fóra com o espírito". Só podemos analisar essa acepção se entendermos como era a edificação na Roma Antiga na época dos autores das citações elencadas pelo lexicógrafo. Na Antigüidade Romana, as habitações eram divididas em insulae (edifícios destinados às camadas populares) e domus (residências maiores unifamiliares e destinadas às camadas mais ricas), ambas com dois pátios ou átrios (local arborizado a que apenas os homens tinham acesso). Havia, também, um modelo peculiar de residência rural, a vila (formada de apenas uma casa, mas habitada por várias famílias).

Voltemo-nos à obra de Bluteau para compreender o gatilho de mudança da palavra FORA na Roma Antiga:

Porta. Deriva-se dos verbos Latinos Portare, e Transportare, por que pelas portas se traz e se leva fóra o que se quer. Porta he abertura na parede, ou no muro de qualquer lugar fechado, e serve para entrar, e sahir. As primeiras portas foraõ as de Cidades, Villas e Povoações assim sae guardar os moradores dellas, como para introduzir os mantimentos. Antigamente com a Relha, ou ferro de hum arado, tirado por hum touro, e h ua vacca se delineava o terreno, em que se 
havia de assentar a cidade, e quando se chegava ao lugar, em que se havia de fazer a porta, era ceremonia, e religiosa observação daquelle tempo levantar, e ter suspenso no ar o ferro do arado, para que a terra do lugar, em que se havia de fazer a porta, não recebesse lesão alguã. Antigamente havia em Roma trinta ortas, donde tomavaõ princípios outras tantas estradas, todas calçadas com incrível trabalho, dispendio e notável cõmodo dos caminhantes. Hoje as portas de Roma são 18. (...) (1713:625) (grifo nosso)

Depois de explicitado o ponto de vista resgatado pela etimologia e união de significados das palavras chave - porta - FORA, percebemos o quanto se tornava fundamental saber como eram os tipos de edificações da Antigüidade. As informações colhidas serviram como indicativo de que à época dos autores das citações havia portas em locais de acesso restrito, como em 'locais que apenas os homens tinham acesso'.

Percebemos também uma semântica às avessas do que se utiliza atualmente no português brasileiro contemporâneo. FORA no exemplo latino remetia ao momento em que o indivíduo se encontrava dentro de casa. Expliquemos: o hábito de estar dentro de casa refletia o momento do descanso, momento em que o indivíduo teria que atravessar a porta e ficar "FORA de circulação", "ausente de situações comunicativas". Como diz o escritor latino: "se estou em casa, ausente é a alma", demonstrando a perspectiva oposta de interpretação que se tinha da palavra sob análise. Dessa acepção à referência do "lado exterior" não foi uma trajetória muito difícil de implementar já no latim.

Um outro lexicógrafo que analisa e descreve a palavra FORA com uma de suas acepções voltadas à palavra porta é Quicherat (s/d) como em:

1- Forás, adv. CIC. VIRG. Para fóra. FORAs edere se. Plaut.

2- Sair. Íbis FORAs. Ov. Irás para fóra, serás mandado embora. I FORAs. Plaut.

3- Vae-te embora, sae d'aqui. (formula do divorcio). Malum FORAs! Tert. 
4- Longe vá o mal! Longe de nós a desgraça! FORAs dari: CIC.

5- Ser publicado. - vendere. Plaut. Pôr com seu dono, vender, Angellus quem locitas FORA. Ter. Campinho que tu arrendas a extranhos. § (?) FORAs caenare. Petr.

6- Jantar fóra (de casa).

7- $\S$ Com gen. FORA de. FORAs corporis. Apul. FORA do corpo.

8- $§$ Prep. De acc. FORAs portam. Hier. FORA da porta (s/d:498)

Em Hieráclito, lemos: "FORAs portam", indicando que o limite restrito fora ultrapassado, tal como dizemos hoje: coloquei porta a FORA. Novamente a referência locativa se faz pelo ambiente de dentro de um espaço físico, delimitado pela porta.

Na evolução diacrônica, encontramos o dicionário de Bernardo de Lima \& Melo Bacellar (1753:221) que apresenta a palavra: "FORA a como isso: a isso (FORAs) para o exterior (phorás) impurrão, repulsa: (phoro isso) tirado isso, ou além disso. V. FORA em estar"14. Pouco acrescenta ao estudo essa notação, pois não há uma contextualização eficiente do uso da época, ainda que percebamos o movimento de interior para exterior associado ao uso da palavra sob análise.

Já no século XIX, encontramos, no dicionário de José da Fonseca, a palavra FORA notada como "Fóra. S.f. a parte externa - de, adv. e prep. da parte exterior: AFORA, excepto; além; sem; longe. Por -, exterormente. Fóra! Interj. apage; tira já" (1848:529), ratificando nossas inferências acerca dos valores semânticos da palavra já na análise que fizemos do material setecentista.

No mesmo século, temos a obra de Antonio de Moraes Silva, que define extensamente a palavra, como reproduzido a seguir. Note-se, no entanto, que a riqueza de acepções também deriva da inclusão de preposições:

\footnotetext{
${ }^{14} \mathrm{O}$ verbete 'estar' se encontra em páginas que não estão legíveis e/ou completas.
} 
FORA, s.f.(do Lat. Foris, is, ou fores, ium, porta, ou do adv. foris, ou forás) A 1- parte externa; oppõe-se á de dentro: v.g. fóra de casa, da cidade: foi para fóra; i.é, de casa. B. 1.8.1.

2- "Ádem, edificada de fóra das portas do mar Roxo"

3- § Livre: v.g. está fóra de perigo (por de fóra, ou em fóra).

4- § Longe, remoto: v.g. está bem fóra d'esses cuidados, trabalhos.

Lus. 3.9. "quem tão fóra estava da na verdade" i.é,

5- que tanto a ignorava, ou estava em tamanho erro. Ac. dos. sing.

2.182. " tão fóra está de implicar hum com o outro estudo (Pallas, com

Bellona; i.é, as sciencias pacificas, com as guerras)"

6- § Estar fóra de ser amigo, ou inimigo; não a ser.

7-§ Fóra de esperança; sem ella: "succedeu-nos isto, FORA de esperança" "coisas fóra de entendimento" que não teem entendimento, insensíveis, irracionáes. Cam. Canç.

8- § A fóra; expecto, demais de. V. do Arc.

9-A fóra, M.P.e. 126. "a fóra esses" i.é, ficando esses á fóra da conta, além d'esses: "á fóra terem tão fracos fundamentos...perdem da opinião" i.é. além de terem etc. Paiva, S.1. p.78. "a fóra de ser mancebo, dava muito ar, e graça, etc." i.é., alem de ser mancebo. Clarim, 2.c.7. sem prepos. "nada delles queria, fóra da salvação de suas almas" i.é,

10- senão, excepto, Luc. 4.9. § “arredando-se a fóra" Palm. 3.f. 108.v i.é., para FORAs.

11-§De fóra parte; além B. Flor. $2.20 \mathrm{v}$

12- § Deixar de fóra; excluir do número, ou não contar, excluir, ou excusar na promoção: e ficar de fóra; não ser admitido.

13-§ Por fóra; Pela parte exterior.

14- § Fazer a viagem da Índia por fóra; era tomar um rumo diverso do que as náos levavam de ordinário. Vieira: no fig. 5.217." a Senhora indo por fóra de todos os exemplos "§Fóra; sem. V.g. fóra de zombaria. It. Sem, ou contra: v.g.

15- fóra de razão: "fóra do costume dos fidalgos d'aquele tempo" Leão Chr. J.I.c.96. §

16-Demas em fóra; i.é, da terra para fóra.

17-§ Jogar de fóra; fig. não ter parte em alguma cousa; ou influir nella, mas sem estar exposto a seus riscos, e incommodos, nem ter nella interesse, e estar despaixonado com animo livre. Eufr. 5.5 
18- § Fóra, usa-se adverbialmente, ou com prep. expressa: "huns dos muros a dentro, outros a fóra" Maus. F. 153. "em fóra" .M e Moça $f$. 89.v.Fóra de quando; exceto quando. B.L. e Cal. 1.274.1. com os verbos de quietação usàmo-lo adverbialmente: v.g. está fóra, janta fóra, ficou fóra, i.é, de casa, por a fóra, á de fóra; se. á parte de fóra.

19- § Ficar de fóra; não entrar na conta, número, no caso, negocio, acção, etc. § Toma se raríssimas vezes como subst. M. v.g. os FORAs d'este palácio são suberbos; i.é, a sua parte exterior: p.us. §. +. NB. Esta dicção é sempre ou advérbio, ou preposição, o auctor qualificou-a de susbstantivo fem. enganado com as expressões, estar FORA, ir para FORA de casa, e outras, em que o artigo de parece nota de genitivo, o qual de sua natureza sempre é regido por um subst. claro, ou occulto, não obstante a opinião dos grammaticos antigos. Para mostrar o engano é preciso mostrar os exemplos: quando ele diz, está fóra de casa; é o mesmo que dizer, está de casa fóra. a partícula de é uma preposição, que rege o artigo $a$, e o subst. casa, que significa lugar d'onde está ausente o sujeito. $\mathrm{O}$ adv. fóra exprime precisamente a ausência do sujeito, porque, estas de a casa fóra, é bem o mesmo que, não estar em casa: ir para fóra de casa, quer dizer, ir de a casa para o lugar que está fóra; branco por fóra, i.é, branco por, ou (como disseram os clássicos) por a parte, que está fóra. De modo similhante se devem supprir as expressões, deixar de fóra, de mar em fóra, jogar de fóra, que todas são ellipticas, assim como est'outras bem vulgares, fóra maroto, fóra bêbado, em que se subentende passa. Quando dizemos, fóra de razão, fóra de zombaria, fóra do costume; as partículas $d a$, de, do, servem para fazer melhor juntura, e poderiam omittir sem erro. Finalmente o modo mais simples e mais natural de explicar a expressão, estar fóra de casa, é dizer que a partícula de se usa para evitar a juntura ingrata, estar fóra casa, que corresponde á locução Latina, essa extra domum. A fóra, é variação, ou alteração de fóra, que ainda se usa muito com a mesma noção, e corresponde, ao menos em apparencia, á preposição Lat. praeter. ${ }^{15}(1858: 53)$

\footnotetext{
${ }^{15}$ As formas abreviadas e suas correspondências são: v.g. - verbi gratia Lus. - Lusitânia Transformada, de Fernão d'Alvares do Oriente. Nova ediç. a pág. Outras vezes o número que está á margem que indica a pág. Da 1.a. edição. Ac. dos Sing. - Academia dos Singulares de Lisboa. o Tom. e pag.

Cam. Canç. - Cancioneiro Geral, de Garcia de Resende. a pagina, e a columna do verso.
} 
Um século depois, Laudelino Freire (1954: 2595-6) expõe que a palavra tem várias funções e a analisa em várias entradas e não somente em uma, como fizeram seus predecessores. Pelos critérios atuais da lexicografia, poderíamos supor que não seriam usos derivados de itens com história e origem distintas (casos de homonímia) e não um caso de polissemia (a um mesmo item vários sentidos foram sendo agregados historicamente), como estamos tratando até o momento. Há, contudo, a ressalva de que esses critérios não são adotados por Laudelino Freire:

FORA, adv. Lat. FORAs.

1.Na face externa; exteriormente: "Pintou a casa por FORA". ॥

2. Em lugar na parte exterior da habitação: "e muitos, que não haviam conseguido lugar, rondavam FORA, apinhando-se às janelas que abriam sôbre o jardim" (C. Neto). "Pelo amor de Deus, vá lá FORA...Veja o que êle quer" (V. de Taunay). ॥

3. Em lugar diverso do da residência habitual: "Passar a noite FORA." || 4.Para distância, para longe: "Deitar FORA alguma cousa". $\|$

5. A parte, em exclusão: "As fronteiras acabavam aonde se fechava o circulo da imitação; e a realidade idealizada ficava de FORA" (Rebelo da Silva). ॥

6. Em pais estranho: Lá FORA, estuda-se mais" (C. de Figueiredo).

7 FORA, prep. Exceto, com exclusão de: "Saíram todos de casa, FORA os criados". ॥

M.P. Fernão Mendes Pinto, Perigirnações o Cap. Paiva, S. ou Sem. O tomo do mesmo nome, Sermões. O Tom e a pag. 1.20 Tomo 1 pg. 20.

Pal,. ou Palmier. Palmeirim d'Inglaterra, 1.a. 2.a.a 3.a. e 4.a.a Parte das edições de 1786 e 1604. a 5.a. parte pro Balthasar Gosalves Lobato.

Clarim - B. Clar. João de Barros, no Carimundo. Edições de 1601. 1702 e 1791. 3 volumes em 8.a.

Luc. O.P - João de Lucena, na vida de São Francisco Xavier, o Livro, e Cap. E se alguma vez cito a pag. É da edição em fol (folia ou folhas)

Vieira ou Vieir. OP. Antonio Vieira, nas usas Obras, a sabaer, Sermões, Cartas, História do Futuro, etc. Quando se cita só Vieira, estendem-se sermões (...) pXIII.

Eufr. Eufrosina, Comedia de Horge Ferreira de Vasconcellos; edição de 1616. Cito primeiro o acto, e depois a scena, e a pag. E a edição; talvez a edição de Farinha.

Maus. Vasco Mausinho de Quebedo, Afonso Africano, Poema. Cito a pag. da ediç. de 1611, ou de 1786.

B.L. e Cal. ( $\mathrm{B}=$ Barros, 3,5 e 8 )

L.= Lobo, obras de Francisco Rodrigues Lobo. (Ediç de fól) N. B. (Nota Bem) 


\section{2. Além de. $\|$}

\section{Longe de. $\|$}

10 4. Afastado de.

11 FORA!, Interj. Arreda! Sai! ॥

12. 2 Grito dos espectadores para chamar ao procênio autores de peças teatrais ou atores, afim de os aplaudir ou patear.

13 FORA DA TERRA, loc. Adv. Nos subúrbios, no interior do país, no campo (falando de uma pessoa residente na cidade).

14 FORA DE, loc. prep. Longe de, distante de: "Tão FORA do mundo ando eu que ainda hoje soube havia entrado nele uma filha de V.S.! (D. Franc. Manuel). "Seria necessário contradizer as testemunhas mais irregragáveis para encontrar FORA das leis imutáveis da Providência a origem dos impérios" (Mont'Alverne) ॥ 15 2. Além de. II

16 3. Contra (denota oposição): "Este amor tão FORA do usual" (Castilho). ॥

17 4. Sem (indica exclusão): "Lindo o gesto mas FORA de alegria" (Camões). ॥

18 5. Pelo lado exterior (indica o lugar onde as cousas estão): "As náiades formasas para ouvi-los com as verdes cabeças FORA d'água suspensas vejo estar" (Diniz da Cruz).

19 FORA DE HORAS.loc. adv. A deshoras, muito tarde: "Parado, FORA de horas, com este frio" (Rebelo da Silva).

20 FORA DE PROPÓSITO. loc. Adv. Alheio ao assunto ou às circunstâncias presentes; despropositado; impróprio da ocasião.

21 FORA DE SI, loc. Adv. Desvairado, exaltado, com a cabeça perdida: !andavam tão FORA de Deus, que não pareciam cristãos, e andavam tão FORA de si, que não pareciam homens" (Vieira)

22 FORA DO NATURAL.loc. adv. Extraordinário, exagerado: “Trejeito tão FORA do natural”(Per. Da Cunha).

23 FORAS, s.m. pl. P. us. A parte exterior.

A preocupação de Laudelino Freire estava voltada aos tipos de expressão que incluíam a palavra FORA, o que justifica esse tipo de organização. Preocupação similar tem Caldas Aulete (1970), ainda que organize a lista de expressões de forma distinta. Já 
neste autor há a presença de outras classes de palavras que não o advérbio, evidenciando o reconhecimento (e aceitação) de usos inovadores:

FORA, adv.

1. exteriormente: Ferve dentro o prazer, reina o sorriso, e FORA a tiritar, fria, medonha a noite. (Gonç. Dias.) \|

2- No estrangeiro: Reina lá FORA grande agitação. || Cá FORA, aqui (em oposição a um lugar que é ou se considera interior): E se isto sucedeu no Paraíso, rei FORA que será, senão o rnesmo? (Vieira.) \| 3-Deixar (alguma pessoa ou coisa) de FORA, não contar com ela, exclui-la do número: Quis contribuir para a festa, mas deixaram-no de FORA. \| Ter ou ficar com alguma parte do corpo ou do vestuário FORA, ser privado dela. tê-la perdido: Com toda uma coxa FORA, que em pedaços the leva um cego tiro. (Camões.) $\|$

4- ficar de FORA, não entrar na conta; ser excluído: Fui ver a lista dos subscritores, o meu nome ficou de FORA. ||

5- Jogar por FORA, jogar carta que não faça vasa. ||

6-Jogar de FORA, não se envolver diretamente nas coisas, não influir pessoalmente nelas proceder de modo que se possa furtar a responsabilidade. \|

7-Deitar-se de FORA, não querer tomar a responsabilidade de qualquer coisa. $\|$

8- De FORA, do lado exterior; de outra nação, de pais estrangeiro: Cuida que estas pedras e estas abobadas resistirão por muito tempo ao impulso de FORA, que as abala? (R. da Silva.)

9- Desprezou a industria nacional e mandou vir toda a mobília de FORA. [Indica o lugar de onde as coisas vêm. ou a causa. Conhecer as pessoas ou as coisas por dentro e por FORA, ter delas perfeito conhecimento: O leitor que não conhecesse por dentro e por FORA a vida da Idade Média, (Herc.) \|

10- Deitar ou botar FORA, rejeitar, abandonar, largar de mão. || Deitar por FORA, entornar, não poder conter. \|

11- Estar, dormir, comer FORA, não estar, não dormir, não comer em sua casa., mas em outra. \|

12- Estar, viver, residir FORA, estar, viver, residir em terra estranha, longe de sua casa ou do seu pais. \| 
13- Estar ou andar FORA dos eixos, não ter tino ou juízo: andar adoentado. || Juiz de FORA. V.juiz ||

14- De em FORA; barra FORA, mar em FORA, pelo mar largo: (fig.) em excesso, em demasia; Já me vou por mar em FORA daqui longe a mover guerra. (Gonç. Dias.) O boato já vai de foz em FORA.\|

15- Prep. AFORA, exceto, sem contar com: FORA isso. peça-me o que quiser. FORA teu irmão, não convido mais ninguém. ॥

16- Além de: Achou vinte mil infantes FORA outra muita gente (J. Fr. de Andrade.) \|

17- FORA de (loc. prep.). longe de. distante de; além de: Tão FORA do mundo ando eu que ainda hoje soube havia entrado nele uma filha de V. S.a. (D. Franc ${ }^{\circ}$ Manuel.) Seria necessário contradizer as testemunhas mais irretratáveis para encontrar FORA das leis imutáveis da Providência a origem dos impérios. (Mon-talverne) ॥

18- Contra (denota oposição); Este amor tão FORA do usual. (Castilho.) \|

19-Sem (indica exclusão): Lindo o gesto, mas FORA de alegria. (Camões.) $\|$

20-FORA de ou por FORA de, ou de FORA de, pelo lado exterior (indica o lugar onde as coisas estão): As Naiades formosas para ouvilos com as verdes cabeças FORA de água suspensas vejo estar. (Dinis da Cruz.) Só vês cordura por FORA. (Gonç, Dias.) ॥

21- Estar FORA de, estar livre, salvo de: O doente está FORA de todo o perigo||

22- Estar FORA de, não se entremeter, não se envolver em: Eu estou FORA dêsses enredos. \|

23-FORA de hora, a desoras, muito tarde: Parado. FORA de hora com este frio. (R. da Silva.) \|

24- FORA de propósito, alheio ao assunto ou às circunstâncias presentes; despropositado: impróprio da ocasião. \|FORA do natural, extraordinário, exagerado: Trejeitos tão FORA do natural. (Per. da Cunha.) \|

25- FORA da terra, nos subúrbios, na província, no campo, no interior do pais (falando de pessoa residente na cidade): $\mathrm{O}$ doente foi tomar ares para FORA da terra.\| 
26-FORA de si, desvairado, exaltado, com a cabeça perdida: Andavam tão FORA de Deus, que não pareciam cristão, e andavam tão FORA de si, que não pareciam homens. (Vieira.) \|

27- Sair FORA de alguma coisa, ultrapassá-la, passar além do que se devia esperar: Um tal fato sai FORA das raias da humanidade. (Herc.) \| 28-FORA de mão, distante: Aos que the ficavam FORA de mão, atirava-lhes com pedras, (Per. da Cunha.) $\|$

29- Estar FORA de pé, estar na agua sem ter os pés no chão: Já perdi o rumo, estou FORA- ||

30- FORA da razão contra o que é razoável; exaltada.||

31- Interj. Arreda! Tira lá $\|$ Modo de chamar os atôres ou autores das peças em espetáculos públicos para os patear.\|

32- FORA o autor! - . s. m. (Brás.) (fam.) ato de recusar a alguém uma pretensão, de livrar-se dêle. de mostrar-se-lhe adverso: Pediu promoção mas recebeu um FORA daqueles! ॥

33- Rompimento ou recusa de namoro: Levou o FORA da namorada. \| (Brás.) (fam.) Dar o FORA, ir-se embora; raspar-se, safar-se. \|

34-Dar o FORA em (alguém), despedi-lo: negar-lhe o pedido; livrar-se dele. $\|$

35- Dar (alguém) um FORA. cometer um erro grosseiro; enganar-se feiamente no partido tomado. || F. lat. FORAs.

Ainda um último dicionário foi consultado, mas pouco pôde contribuir dada sua concisão de informações. Referimo-nos a Silveira Bueno (1956:559): “FORA, adj. 1Na parte exterior; em pois estranho; 2- prep. exceto; com exclusão de; 3- interj. para expulsar, nos teatros, para patear".

Observamos, até aqui, que os lexicógrafos analisaram as acepções em comum, mas, com o passar do tempo, a acepção que inclui a idéia chave-porta foi apagada, como se nunca houvesse havido uma relação entre essa idéia e a palavra sob análise.

Preocupado com a datação, Cunha (1982:364) informa que a palavra FORA inicia sua trajetória no português do século XIII: “FORA adv. 1- 'na parte exterior'|XIII, FORAs XIIIi| dolat. Fõras|| 2- AFORA adv. 'longe de, para FORA de' 
XIII 3- prep. 'com exceção de, exceto' XIII. do lat. afforas”, ainda guardando veios de significações presentes no latim tardio. Essa datação é ratificada por Houaiss (2007): datada de 1038, sua etimologia provém do latim: “adv.lat. fòras 'para FORA, na parte exterior'; no port. arc. ainda us. com o -s final; f.hist. sXIII FORA, sXIII FORAs”.

Várias são as definições em que Houaiss \& Villar (2001:1369-1370) expõem a palavra em análise de forma mais completa, iniciando com as acepções:

- advérbio

1 na parte exterior de (um prédio, um recinto etc.) Ex.: <a bicicleta está lá f., no jardim><há uma pessoa esperando aí f.>

2 na face externa de (algo) Ex.: dentro, as janelas eram pintadas de azul, e FORA, de branco

3 algum lugar diverso da residência habitual Ex.: < quando o deputado está f., seus assessores recebem os postulantes> $<$ avisou que ia dormir f. $><$ não gosta de comer f. $><$ trabalhar f. $>$

4 no estrangeiro Ex.: <lá f. as instituições funcionam>< $>$ nos quatro anos que passou f., muita coisa mudou>

5 no lixo; na lixeira Ex.: jogar f. papéis velhos

6 de maneira a separar (uma parte) do todo Ex.: cortou f. a manga do vestido

7 Estatística: pouco usado. em toda a extensão; ao longo de; AFORA Ex.: pela vida f. m preposição

8 com exceção de, salvo, exceto Ex.: os fugitivos FORAm recapturados, f. uns dois ou três

9 além de, ademais de, AFORA Ex.: f. os familiares, muitos amigos o apoiaram - interjeição

10 exclamação que denota ordem para sair, deixar um lugar; saia! sai! suma daqui!

11 Rubrica: esportes. exclamação de que a bola tocou o chão FORA do quadrilátero da quadra, como no vôlei, p.ex.

12 Rubrica: teatro. Diacronismo: obsoleto. grito chamando ao proscênio o elenco, o autor ou pessoas responsáveis pelo 
espetáculo, no intuito de vaiar ou de aplaudir

substantivo

masculino Regionalismo: Brasil. Uso: informal.

13 algo inoportuno, sem razão de ser; gafe, rata, mancada Ex.: não ter comparecido à festa do chefe foi um $\mathrm{f}$. terrível

14 demonstração de ignorância, desconhecimento Ex.: ele se mete a falar de coisas que não entende, aí só dá f.

15 Regionalismo: Brasil. tratamento desdenhoso; recusa, rejeição Ex.: $<$ ficou doente com o f. que recebeu da garota $><$ levou um $\mathrm{f}$. quando foi pedir aumento ao patrão $>$ FORAs — substantivo masculino plural Estatística: pouco usado.

16 a parte exterior; arredores, exteriores.

Com relação às acepções sincrônicas, Houaiss \& Villar (2001:1969) apresentam diversas, coincidindo com Cunha (1982) apenas em três delas. O advérbio significando 'para FORA, na parte exterior' ${ }^{16}$ associa-se a contextos em que se pede uma oposição espacial específica: a face externa de algo > algum lugar diverso da residência habitual $>$ o estrangeiro. Pode ser empregado num contexto em que se pretenda separar uma parte do todo, tal como associado ao verbo jogar, cujo resultado é a interpretação “colocar no lixo ou na lixeira". Pode também se associar a outras partículas, como a preposição prefixada $a$, gerando a palavra AFORA. A segunda acepção revela sua recategorização para preposição, assumindo o significado de com exceção de, salvo, exceto. A terceira acepção inclui a palavra FORA como uma interjeição que denota ordem para sair, para deixar um lugar. Ainda como interjeição, o item FORA pode indicar o fato de "tocar o solo/chão" em contexto de alguns jogos, como o voleibol, revelando um parâmetro não aceito diante de regras pré-existentes.

Tendo em vista que FORA deriva do latim, julgamos pertinente observar sua trajetória em outras línguas românicas. Escolhemos, para tanto, o francês e o italiano.

\footnotetext{
${ }^{16}$ No português arcaico era usado com o -s final (f.hist. sXIII FORA, sXIII FORAs), o que o tornava mais próximo da forma latina fŏras.
} 
Consultamos, nessa empreitada as obras de Bloch \& Von Wartburg (1932) e de Ernout \& Meillet (1951), referentes ao francês:

hórsum: adv.: de ce côté-ci. Archaïque (Pl. et Tér. De hõ-uor-sum)V. seorsum ${ }^{17}$ (Ernout \& Meillet 1951:535)

seorsus, - $a$, -um: Qui est à l'écart. à part. Rare dans cet emploi; usité surtout comme adverbe et preposition sous la forme seorsus, seorsum (sorsus, sorsum)" à l'ecart, à part (de); usuel, mais semble évité par la prose classique (non dans César, une seule fois dans Cic., évité aussi par Vg. et Hor). ${ }^{18}$ (Ernout \& Meillet, 1951:1085)

'Tiré de dehors qui représente le lat. de basse ép. deforis; entre voyelles le ' $\mathrm{f}$ ' disparait normalement cette forme deors a pris un $h$ dans l'exclamation emphatique, d'oú il s'est par la suite généralisé. fors, hors d'usage depuis le xvii s., représente le lat. forís, esp. fuera (de-as) . L'Est et le franco-provençal disent defors, le Midi defors, deFORAs; fors ne survit que dans l'Est'. ${ }^{19}$ (Bloch \& Von Wartburg, 1932:324)

Notemos que, em Bloch \& Von Wartburg (1932), há a ratificação do percurso do latim para o francês, para o espanhol e para o franco-provençal; entretanto, no francês e no franco-provençal, há a agregação da preposição de. Esse tipo de junção é também comum no português com a palavra AFORA, porém privilegiando a preposição A.

Na língua italiana, Devoto \& Oli (1988) apresentam em sua obra a palavra fuòri com acepções muito próximas das que temos em português e em francês, porém não

\footnotetext{
${ }^{17}$ Nossa tradução: hórsum: adv.: deste lado. Arcaico. (Pl. et Tér. De hõ-uor-sum) V. seorsum (Ernout \& Meillet 1951:535)

${ }^{18}$ seorsus, -a, -um: Que está afastado, à parte. Raro neste emprego, usado sobretudo como advérbio e preposição sob a forma afastado, à parte (de) ; usual, mas parece evitado pela prosa clássica (não em César, uma única vez em Cícero, evitado também por Virgílio e Horácio) (Ernout \& Meillet, 1951:1085)

${ }^{19}$ Tirado (ou puxado) do exterior que representa o baixo latim. deforis; entre vogais, o f desaparece; normalmente formando deors que é acrescido de um h na exclamação enfática, donde foi, em seguida,
} 
inclui a forma prefixada AFORA, talvez porque ainda existam nessa língua mais vestígios dos casos latinos:

1. fuori (pop. fòri e fóra; arc. e poet. fuòra; arc.fòre e fuòre) avv. e prep. 1. (1.) avv. All'esterno di um limite (spec. Del perímetro della casa o del paese), unito per lo più com verbi di moto o di quiete: f.era freddo; c'è f. un tizio che cerca di te; sono stato f. tutto il giorno; pranzare, cenar $f:$ à gente venuta di $f$.

2. Può avaere valore di interiezione per espellere o per chiamare (fuori, dall'aula; fuori! Dal sipario) e, con di premesso, valore sostantivale (il di f.; al di f. Er gradevole)

3. (2.)Come prep. È di norma seguito da di: f. Dic asa; f. D'Italia; f. Del campo; fig.: esser f.di sé, in preda all'ira; mettersi f. Della legge; viver $f$. Del proprio tempo

4. Giustapposto a un sostantivo dà luogo a locuzioni avverbiali (essere f. Stanza; trovarsi alfine f. Pericolo; monetaf. Corso, che non há più valore legale; tavole $f$. testo., v. Tavola; mettere $f$. combattimento, v. FUORICOMBATIMENTO) oppure a locuzione attributive (asservazione f. luogo,

5. inopportuna; luogo f. mano, lontano dall'abiato, isolato, remoto; voce, suono f. campo, nella terminologia cinematografica, di voce o suono provenienti, da persone o cose che non si vedono sulla scena) e anche a sostantiviautonomi (v. FUORICLASSE, FUORILEGGE, FUORISTRADA, ecc). [Lat. foris, foras]

Uma estratégia interessante para se compreender o deslizamento funcional de um item equivale a proporcionar uma organização comparativa dos valores semânticos citados em cada autor.

generalizado. fors, FORA de uso, desde o século XVII, representa o latim foris, espanhol fuera (de-as). O 


\section{Comparando com acepções assumidas historicamente}

Passemos à ampliação de significação que dá conta da polissemia da palavra FORA no português do Brasil. Para esta empreitada, lançamos mão do conjunto de dicionários consultados a fim de providenciar uma comparação da ordem de entrada de cada acepção. Queremos, com isso, depreender se o critério de organização lexicográfica, representada pela priorização de sentidos mais amplamente empregados (não-marcados), pode ser ratificado.

A palavra sob análise apresenta-se categorizada na classe dos advérbios, razão pela qual seu uso mais antigo é invariável quanto ao número e expressa a circunstância de um verbo ${ }^{20}$. Pode-se, ainda, depreender que, numa vertente tradicional, se trata de um termo não-essencial, modificador do sentido de uma oração ou de toda uma sentença, acrescentando-lhe nuanças modais ${ }^{21}$.

Retomando a discussão sobre o advérbio alvo desta pesquisa, podemos sintetizar o consenso observado a respeito de sua origem latina: indica uma perspectiva de localização, tal como afirmado em Michaelis (on-line):

1 Exteriormente, na face externa: Pintar por FORA. 2 Em lugar diferente do da residência habitual: Dormir FORA. 3 Para longe: Lance FORA isso. 4 Em país estranho: Viajar mundo a FORA.

Além dessa acepção mais adverbial, também são listadas por Michaelis suas recategorizações como preposição e como interjeição:

\footnotetext{
Leste e o franco-provençal dizem defors, o Sul defors, deFORAs; fors não sobrevive a não ser no Leste.

${ }^{20}$ Temos consciência de que advérbios, pelas definições gramaticais, podem ter como escopo o adjetivo, o verbo e mesmo um advérbio. Devemos, contudo, esclarecer que o advérbio FORA, embora tenha todas essas possibilidades, somente englobe e amplie o significado pertinente ao verbo.

${ }^{21}$ Essas informações nem sempre coincidirão com o que de fato ocorre com todos os advérbios nas línguas. Essa é a razão por que consideramos que a vertente tradicional de classificação de morfológica de palavras deva integrar esta dissertação apenas como contraponto ao que de fato identificamos como usos reais.
} 
5. (1) Exceto, menos: Saíram todos, FORA a professora.

6.(2) Afastado de: FORA dos eixos.

7. (3)Além de: FORA eles, havia mais um. “, ou como

8. interjeição: "Arreda!, sai! FORA de horas: a desoras, muito tarde.

9. FORA de propósito: impróprio da ocasião; inconveniente; inoportuno.

10.FORA de si: desvairado, exaltado.

11.FORA do natural: excessivo; FORA das proporções naturais.

12. Dar o FORA: a) ir-se embora, raspar-se; b) romper namoro ou noivado.

Comparando as acepções encontradas nos vários dicionários consultados sem perder de vista a ordem de aparição na lista de acepções, temos o seguinte resultado:

Quadro 2 - Resumo comparativo das acepções em dicionários ${ }^{22}$.

\begin{tabular}{|c|c|c|c|c|c|c|c|c|c|c|c|}
\hline Acepção & 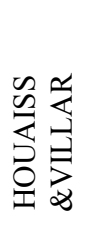 & 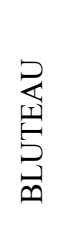 & 党 & 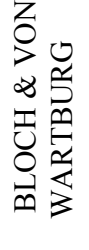 & 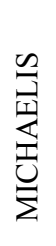 & 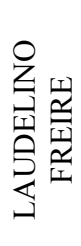 & 足 & 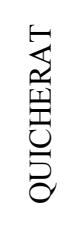 & 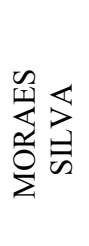 & $\begin{array}{l}\overrightarrow{1} \\
0 \\
\infty \\
0 \\
0 \\
0 \\
1 \\
0\end{array}$ & 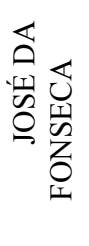 \\
\hline $\begin{array}{l}\text { 1a. - a parte exterior (adv. } \\
\text { locativo - perspectiva ) }\end{array}$ & 1 & 1 & 1 & 1 & 1 & $\begin{array}{c}1 \\
18 \\
23\end{array}$ & 1 & $\begin{array}{l}1 \\
2\end{array}$ & $\begin{array}{r}1 \\
12\end{array}$ & 1 & 1 \\
\hline $\begin{array}{l}\text { 2a. - a face exterior } \\
\text { (adv.locativo - faces de um } \\
\text { objeto) }\end{array}$ & 2 & 12 & & & & 2 & $\begin{array}{c}8 \\
20\end{array}$ & 8 & $\begin{array}{l}2 \\
4\end{array}$ & 2 & \\
\hline 3a. - lugar diverso do habitual & 3 & & 2 & 3 & 2 & $\begin{array}{c}3 \\
14\end{array}$ & $\begin{array}{l}11 \\
25 \\
28\end{array}$ & 6 & 13 & 3 & \\
\hline $\begin{array}{l}\text { 4a. - FORA do país/cidade; no } \\
\text { estrangeiro }\end{array}$ & 4 & $\begin{array}{c}4 \\
10\end{array}$ & 2 & & 4 & $\begin{array}{c}6 \\
13\end{array}$ & $\begin{array}{c}2 \\
9 \\
12 \\
17 \\
24 \\
\end{array}$ & & 4 & & \\
\hline $\begin{array}{l}\text { 5a. - desfazer-se de algo, } \\
\text { colocar no lixo }\end{array}$ & 5 & 2 & & & 3 & $\begin{array}{c}4 \\
17 \\
\end{array}$ & $\begin{array}{c}7 \\
18 \\
\end{array}$ & & 18 & & \\
\hline 6a. - separar uma parte do todo & 6 & $\begin{array}{c}8 \\
14\end{array}$ & & & $\begin{array}{l}7 \\
9\end{array}$ & $\begin{array}{c}5 \\
10 \\
21\end{array}$ & $\begin{array}{c}5 \\
6 \\
13 \\
26 \\
\end{array}$ & 7 & 8 & & \\
\hline
\end{tabular}

${ }^{22} \mathrm{O}$ critério que cada autor utiliza para compor seu dicionário influenciará a ordem de aparecimento de cada sentido. Há outras separações das acepções dadas pelos autores, entretanto, tentamos agrupá-las em 14 conceitos constantes na maioria dos dicionários pesquisados. Eles podem ser continentes de mais de uma acepção. 


\begin{tabular}{|c|c|c|c|c|c|c|c|c|c|c|c|}
\hline Acepção & 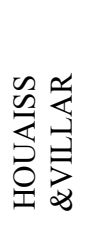 & 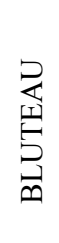 & $\begin{array}{l}\text { 志 } \\
\text { 足 }\end{array}$ & 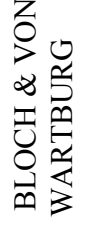 & 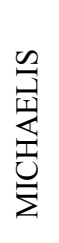 & 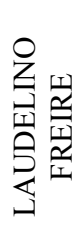 & 菿 & 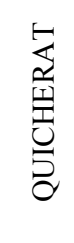 & 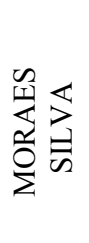 & $\begin{array}{l}\overrightarrow{3} \\
0 \\
\infty \\
0 \\
\circ \\
0 \\
د \\
د \\
0\end{array}$ & 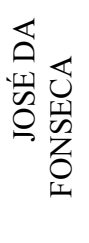 \\
\hline $\begin{array}{l}\text { 7a. - em toda a extensão, ao } \\
\text { longo de }\end{array}$ & 7 & & & & & 9 & $\begin{array}{l}14 \\
16 \\
\end{array}$ & & & & \\
\hline 8a. - com exceção de (prep.) & 8 & $\begin{array}{l}5 \\
7\end{array}$ & 3 & 3 & $\begin{array}{c}4 \\
10\end{array}$ & $\begin{array}{c}7 \\
15\end{array}$ & $\begin{array}{l}15 \\
20 \\
29\end{array}$ & & $\begin{array}{c}3 \\
9 \\
11 \\
19 \\
\end{array}$ & 3 & 2 \\
\hline 9a. - além de (prep.- inclusivo) & 9 & $\begin{array}{l}14 \\
15\end{array}$ & & & $\begin{array}{l}3 \\
6\end{array}$ & $\begin{array}{c}8 \\
15\end{array}$ & $\begin{array}{l}16 \\
18 \\
19 \\
27\end{array}$ & & $\begin{array}{c}8 \\
10 \\
15 \\
17\end{array}$ & 4 & 3 \\
\hline $\begin{array}{l}\text { 10a. - interjeição - para o lado } \\
\text { externo }\end{array}$ & 8 & & & & $\begin{array}{l}4 \\
7\end{array}$ & 11 & $\begin{array}{c}5 \\
31\end{array}$ & 4 & & 2 & \\
\hline $\begin{array}{l}\text { 11a. - ordem para sair } \\
\text { (exclamação) }\end{array}$ & 10 & $\begin{array}{l}6 \\
7 \\
9 \\
\end{array}$ & & & 7 & 12 & 32 & 3 & & 2 & \\
\hline $\begin{array}{l}\text { 12a. - algo inoportuno, sem } \\
\text { razão de ser, gafe }\end{array}$ & 11 & 13 & & & $\begin{array}{l}5 \\
8\end{array}$ & $\begin{array}{l}19 \\
20\end{array}$ & $\begin{array}{l}23 \\
30 \\
35 \\
\end{array}$ & & & 5 & \\
\hline $\begin{array}{l}\text { 13a. - falar sem conhecimento } \\
\text { de causa, ignorar }\end{array}$ & 12 & 11 & & & & & $\begin{array}{l}14 \\
22 \\
24\end{array}$ & & & & \\
\hline 14a. - 'FORA' pleonástico & 13 & $\begin{array}{l}3 \\
7\end{array}$ & & & & 22 & & 2 & & & \\
\hline $\begin{array}{l}\text { 15a. - recusa, rejeição, } \\
\text { tratamento desdenhoso }\end{array}$ & 14 & 9 & & & $\begin{array}{c}5 \\
10\end{array}$ & $\begin{array}{l}12 \\
17\end{array}$ & $\begin{array}{c}3 \\
4 \\
10 \\
19 \\
31 \\
32 \\
33 \\
34 \\
\end{array}$ & & $\begin{array}{l}14 \\
16\end{array}$ & & \\
\hline
\end{tabular}

Os critérios para a explicitação das acepções são iniciados pelas constantes do dicionário Houaiss e Villar (2001) da $1^{\mathrm{a}}$ à $15^{\mathrm{a}}$ acepção. Esse número de acepção é admitido por ser este um dos dicionários mais completos e atuais ao qual recorremos nesta instância da pesquisa. Tanto nele quanto nos demais dicionários, podemos notar que o uso mais básico ainda continua sendo aquele que denota o lado exterior de um espaço físico. 
Atentamos que os lexicógrafos Laudelino Freire, Quicherat e Moraes Silva desenvolveram outras acepções que se encaixam nesta primeira.

Dos onze dicionários consultados, encontramos sete com a segunda acepção: a parte exterior como advérbio locativo determinando as faces de um objeto, talvez por ser uma acepção tão específica sua recorrência se torne menos freqüente.

Há oito lexicógrafos que explicitam o item FORA como o lugar diverso do habitual na terceira acepção (note a novidade da habitualidade desta acepção). Mais distante do falante se mostra a quarta acepção: FORA do país ou cidade, no estrangeiro, notemos os vários exemplos em momentos diferentes no dicionário de Caldas Aulete.

Nas quinta, sexta e sétima acepções: desfazer-se de algo, colocar no lixo, há o desfecho do caminho feito pelo item FORA desde denotar a parte exterior, com tênue distância do falante, até o jogar FORA, ou o separar uma parte do todo e em toda a extensão, afirmando a total distância do mesmo.

De uma primeira noção adverbial, a palavra FORA passa a ser observada como preposição na oitava acepção significando exceto e na nona, além de, ambas muito antigas (encontradas em Bluteau) e ainda hoje recorrentes, com diversas outras acepções nos demais dicionários que se encaixam a essa.

O item FORA como interjeição e em exclamação também tem alta freqüência em várias acepções nos dicionários pesquisados, ambas se encaixam na décima e décima primeira acepções do de Houaiss e Villar (2001). A décima quarta acepção é formada pela repetição da palavra em análise, contamos apenas quatro ocorrências, pode-se inferir que, nessa acepção, o verbo fora 'apagado' e o item $\boldsymbol{F O R A}$ já expressa a condição contextualmente de ação. 
Diante do eixo sintagmático, a palavra FORA pode se categorizar como um substantivo, como é notado nas demais acepções (da décima segunda até a décima quinta): algo inoportuno, gafe, ignorar, recusa e rejeição.

Há mais duas possibilidades de entendimento da palavra em análise. Uma aparece apenas no dicionário Quicherat (s/d): FORA como algo a ser publicado, a ser vendido. Hoje, essa acepção não tem mais respaldo na comunidade usuária da língua natural. A outra em Ernout e Meillet (1951) como primeira acepção de advérbio significando deste lado, que é o lado mais próximo ao campo dêitico do falante.

Observamos, também, discrepância em relação à ordem de apresentação das acepções nos diversos dicionários. Há os dicionários que fixam a palavra sob análise numa categoria de advérbio, denotando a distância entre o objeto e o falante, o que nos leva a crer que advérbio locativo percorre um continuum de perspectiva física para mental. Mesmo os casos em que fora assumiria um valor semântico mais abstrato seriam provenientes de uma mesma trajetória história, portanto todos os casos identificados seriam casos de polissemia (mesma origem) e não de homonímia (origens distintas).

\section{Sistematização nas gramáticas}

Após essa série de discussões acerca do valor etimológico do advérbio FORA e de suas acepções registradas em dicionários de épocas variadas, procedemos a uma incursão pelas gramáticas normativas do português. Selecionamos para esta tarefa as gramáticas de Cunha \& Lindley Cintra (1985) e de Bechara (1999). Esta última ressaltamos - ainda que mantenha muito do seu caráter normativo, já incorpora muitas das descobertas científicas da área lingüística do século XX. 
Nossa intenção com essa incursão é saber em que categorias gramaticais figuraria a palavra FORA. Essa informação é importante, pois o rótulo de "uso inovador" é normalmente atribuído àqueles usos que não foram incorporados pela gramática escolar e/ou tradicional.

Segundo os autores consultados, o advérbio tem por função principal a modificação verbal, mas essa função estende-se também a outras classes, como é o caso do adjetivo e do próprio advérbio.

Cuidadosos, os autores observam que essa amplitude de designações faz com que o advérbio seja freqüentemente reexaminado por lingüistas modernos tanto no que se refere a seu estatuto funcional quanto ao seu valor semântico.

Em Cunha \& Lindley Cintra (1985:530), o advérbio FORA figura entre os advérbios de lugar e também entre as preposições acidentais ao lado de AFORAS (1985:543). Em Bechara (1999:305), figura como advérbio de lugar (1999:290) e como locução prepositiva na forma FORA de.

A despeito da ausência da função prepositiva de $\boldsymbol{F} \boldsymbol{O R} \boldsymbol{A}$ na lista de conjunções indicadas normativamente, como forma simples, há em Bechara (1999:299) a explanação acerca das unidades adverbiais e adjetivais convertidas em preposições. Sob esse pretexto, o autor cita a preposição FORA, exemplificada da seguinte maneira: FORA os alunos ninguém mais pôde entrar no salão.

Ressalta, ainda, Bechara (1999:288) que é bastante produtiva na língua portuguesa a posposição da partícula que a advérbios, gerando locuções conjuntivas adverbiais: "A rigor, trata-se de um grupo de palavras que, por hipotaxe, funciona como conjunção”. Não há, no entanto, nenhuma referência à locução FORA que. 
A partir dessas considerações, pode-se tratar do advérbio como uma categoria que também assume variadas e sucessivas recategorizações condicionadas às situações comunicativas demandadas:

...apreensão do mundo extralingüística, a forma da intuição da realidade ou, ainda, o modo de ser das palavras no discurso, e não classes léxicas fixas. (BECHARA, 2001:109)

Há também a visão funcionalista evidenciada em Neves (2000:271-272) ao explicar que o item FORA faz parte das propriedades distribucionais dos circunstanciais de lugar, ou seja, os não-fóricos, ainda explicita que eles podem ocorrer como sintagmas preposicionados e é nesse ínterim que encontramos, dentre os não-fóricos, o item FORA.

Se de um uso mais lexical, como o adverbial, passamos a reconhecer a existência de um uso prepositivo, então nos parece que existe uma direção para a mudança observada até o momento. É justamente sobre a organização unidirecional dos padrões funcionais da palavra FORA que tratamos na seção seguinte.

\section{Padrões funcionais do item FORA no português do Brasil ${ }^{23}$}

Nesta seção, apresentamos o resultado de uma organização que prioriza o critério da abstratização unidirecional da palavra-fonte adverbial FORA em suas sucessivas recategorizações e deslizamentos funcionais, já que consideramos que sejam desenvolvimentos históricos de um mesmo item (caráter polissêmico). Ao providenciar a organização, notamos, contudo, que alguns padrões seriam derivados de processos em

\footnotetext{
${ }^{23}$ Poder-se-ia adotar a terminologia 'uso' ao invés de 'padrão de uso', mas a palavra isolada seria ambígua em relação a um dos métodos de contagem da freqüência de uma palavra: o type (Bybee,2003), ou seja o 'uso'. Aqui a palavra 'padrão' não se relaciona ao que é normativamente indicado como "melhor", "correto" ou "modelar". Refere-se à repetição de uma formação lingüística.
} 
direção à gramática enquanto outros seriam derivados de processos em direção ao Léxico.

Dividimos esses dois grandes casos em padrões funcionais mais pormenorizados. Devemos, no entanto, esclarecer que integram processos de mudança distintos. Enquanto o item que vai em direção à gramática sofre gramaticalização, o outro que vai em direção ao Léxico sofre lexicalização.

\subsection{Gramaticalização do Item FORA ${ }^{24}$}

Nesta seção, apresentamos os padrões funcionais identificados a partir dos dados coligidos nas amostras.

FORA1 - neste subgrupo reúnem-se os casos em que FORA assume o papel de advérbio, invariavelmente colocado em posição pós-verbal. Nessa situação de uso, ele pode ser parafraseado por quaisquer expressões que denunciem a oposição interior/exterior, remetendo à categoria espacial externa. Acompanha-se freqüentemente por um dêitico, do tipo aí, aqui e lá.

(6) F- Olha, brincava-se muito de roda e - aquele grupinho, não é? (Está) e <ti..>-podia brincar aí FORA à noite. (Peul-c-10)

E: Você prefere mais sé profissional liberal... as diferenças entre..,[profissional liberal e funcionário público?]

(1) F: [Acho que aqui FORA é melhor prá se trabalha] do que funcionário público, funcionário público tem que manda. Veja bem meu caso na área de educação (Peul- r-9) 
(8) F: Olha, cê sabe que num dá prá mim vê direito porque eu fico (hes) eu pego oito horas, entro lá pró meu setor. [só saio quase] só saio duas hora prá bate o ponto, aí volto pró meu setor. fico lá dentro, leio jornal, conversando, aí volto três hora. bato o meu ponto na entrada do almoço. E«tro e só saio na hora de i embora. Quase num vejo segundo grau, sabe?, lá FORA, quase num vejo. (Peul - r-8)

FORA2 - integrado a um sintagma preposicionado de caráter adverbial intensificador, a palavra FORA toma por escopo o advérbio que o antecede. Seu antecedente é um advérbio dêitico.

(9) Eu saía por esse canal, ("eu") ia pescar lá em cima com um colega, no domingo, ou lá para FORA- (est) mas a pescaria é uma coisa muito incerta, não é? (Peul- c-3)

(10) Bélgica. Bruxelas. França. Paris. E no outro dia. [ meus ]...[ meus ],..meu neto ficaram: mais vovô... E as sobrinhas lá de FORA também. [ que ]...que eu tinha o ginasial e eu digo: não, eu tenho o quarto ano primário, porque naquele tempo você estudava mesmo, sabe como é? (Peul- r-15)

FORA3 - Um dos casos bastante recorrentes também inclui preposição e sinaliza a presença de uma exclusão, mas ainda subcategoriza-se como uma expressão adverbial de cunho temporal e também locativa.

(11) F: (Inint) parece um carnaval FORA de época (inint). (Peul- r-16)

(12) Esse embrião, uma vez FORA do ventre materno que o gerou (,..)(MASSI, MLGDissertação- p.111)

(13) Você sai, assim, muito daqui, você se diverte FORA do bairro [ou]- (hes) ou mais aqui dentro mesmo? [você tem-] (Peul- c-15)

(14) As motivações externas baseiam-se na relação entre a coisa significada e a forma significante FORA do sistema lingüístico. (ANJOS, E D - Dissertação p-190)

\footnotetext{
${ }^{24}$ A escolha de Padrões Funcionais foi feita a partir das várias formações em que o FORA se encaixa. Todos os casos identificados são casos de polissemia, posto que há a mesma origem de advérbio como 'lado externo'.
} 
(15) O termo giro, FORA do contexto capoeirístico (...) (ANJOS, E D - Dissertação- p197)

(16) (...) prevendo a sua soberania ameaçada por um possível poder FORA do seu controle, por precaução, limita essa potência arrebatando-lhe a filha. (MASSI, MLGDissertação P-112-)

(17) Mas, os pais ocupantes de altos postos, embora honrados e cobertos de glória FORA de casa (...)(MASSI, MLG-Dissertação-p.88)

(18) Sou uma mulher, sei lá! FORA de série, sabe? (Peul- c-12)

(19) F - [ah!] não, muitas não estarão, não é? Muitos já estão já- não é? FORA de forma, não é? (Peul- c-16)

(20) (...) o discurso lobatiano FORA dos padrões (GOH, Simone Strelciunas Dissertação- p.13)

(21) (...) sua definição etimológica- mesmo que imprecisa, FORA de um contexto e que servirá de origem (...) (GOH, Simone Strelciunas - Dissertação p-71 -)

(22) Há umas coisas FORA de foco. (GOH, Sirnone Strelciunas - Dissertação-p. 178)

(23) A função básica dos pronomes, afirma, é indicar a noção de pessoa. Explicita a noção de pessoa, sempre se remetendo ao evento comunicativo como uma estrutura, em que há um ou mais falantes (eiu nós), um ou mais ouvintes (tu/vós) e os seres que ficam FORA do eixo falante-ouvinte (ele/ela/eles/elas). (MODESTO, A T T - Dissertação p17)

(24) ...decorrente das migrações constantes FORA do limite do grupo. (GOH, Simone Strelciunas - Dissertação p-55)

FORA4 - Neste subconjunto de dados, a palavra FORA, antepondo-se a um sintagma nominal, recategoriza-se como preposição. Seu valor original de ausência no espaço físico delimitado permite a implementação de uma preposição de exclusão da informação a ele subseqüente. Pode ser parafraseado por exceto. Parece-nos que o exemplo ilustrativo de Bluteau (1713:160) já atesta o uso prepositivo no século XVIII: 
“AFORA. Vid. Alem. Vid. FORA. AFORA estes argumentos se achaõ algumas pedras na cidade . Corograph de arreiros (pag 2. vers.).

(2) E: Ah, é ? E faz muito tempo que você mora aqui em Campo Grande?

F: Faz, uns vinte anos.

E: Ah, é ? Ah... sim. É... você já morou em outros lugares ? (Est) FORA o Aterro onde você nasceu...

F: Irajá e Anchieta. (Peul-r-adri)

(25) F: Tem que madrugar, durmo de um dia pro outro se for preciso. Passa dois, três dias na fila isso por quê ? Porque é um colégio bom.

E: Aí todo mundo quer, né?

F: Aí todo mundo quer... FORA disso só pagano (Peu3- r-2)

(26) Faltaram no texto paraguaios falsos, colombianos cheiradores e chilenos magérrimos de 2,20m. Isso não surpreende ninguém que leia este blog e percebe o quanto eu ignoro a América Latina, estando exilado em meu próprio cérebro desde 1994. Mas não ter encaixado holandeses maconheiros, finlandeses incompreensíveis e atrizes pornôs tchecas é algo por qual devo ser severamente criticado. FORA isso, comprem guarda-chuvas de aço, porque o Solon agora tem blog. É, é, não é só dele, é só sobre esportes. Tudo bem. Daqui a seis meses ele já está trabalhando com a teoria que a política é o spectator sport para os gordos assim como é o show biz dos feios. (http://ciscocosta.com/fílisteu/?cat=34)

(27) Moderador apresenta a mensagem enviada por naninha: Qual foi seu pior momento na casa?

Rogério responde para naninha: Não tive um pior momento, não tive um conflito. Acho que este horário meio doido, dormir tarde, almoçar tarde, deu uma alterada. Mas FORA isso, não tive nada de ruim (http://videochat.globo.com/GVC/ arqinvo/O..GO6244-3362.00.html)

(28) Falando em brasileiro, nunca vi tantos juntos em um soh lugar como aqui na Berlitz, Soh na minha sala tem 04 alem de mim. na minha homestav 01 e FORA o restante das escola, parecem que foram selecionados a dedos. Bom. se não en corenano. en brasileiro, rssss, (http://FORAdecasa.blogger.com.br/) 
(29) Sabe? se falo: olha. quero fica sozinho, ela tem que respeita, agora existe, FORA nós dois, cada um ser uma pessoa, nós, por nós casarmos, existe um outro terceiro ser. que e justamente o nosso casamento. (Peul- r-6)

(30) Não perca esta chance, cadastre-se agora mesmo em um dos nossos e-mails. Lembrando que todos eles tem a garantia de que ninguém (FORA você mesmo) estará lendo o seu e-mail. ou seja. você terá privacidade total. (http://orbita.starmidia.com/frasez/seuemail.htm )

(7) Há tempo venho falando que o SPFC neste ano (FORA um ou dois jogos) não vem correspondendo com um bom futebol. Isso até certo ponto é normal pois perdemos peças fundamentais de conquistas recentes, como Danilo, Mineiro e Fabão. (http://www.saopaulofc.com.br/articles.php?id=576)

FORA5 - considerado o uso mais inovador, o item sob análise é sucedido por uma palavra que, com a qual constitui uma locução aparentemente conjuntiva. Na verdade, trata-se de um operador argumentativo sinalizador de adição de mais um argumento. $\mathrm{O}$ uso da expressão FORA que parece sinalizar ao interlocutor que o falante considera que o argumento que se seguirá detém um argumento óbvio e incontestável.

O FORA que como um marcador discursivo engendra-se no nível sintático. Ele, também, 'desfocaliza ${ }^{25}$, a informação anterior (velha) e carrega outra informação semântico-pragmática (Traugott,1982), ou seja, ele avisa ao interlocutor da ‘focalização' de uma nova informação.

(4) "Eu deveria ter nascido aí. Pois tirando a minha aparência (risos), gosto das mesmas coisas que vocês. Dançamos a mesma música, bebemos as mesmas bebidas, rimos das mesmas piadas. Esta será a minha única turnê no ano", diz o simpático inglês. "Decidi tocar porque amo o Brasil e os brasileiros. Eles

\footnotetext{
${ }^{25}$ Os termos 'focalização' e 'desfocalização' foram adaptados da obra Eastern Otomi Verbs, "Semology and Transitivity in Eastern Otomi Verbs". 'Defocusing' significa o abandono da informação anterior para a tomada de outra informação (focusing) (1972,p.29).
} 
parecem gostar de mim, também. FORA QUE ${ }^{26}$ o tempo na Inglaterra nesse período do ano é horrível”, justifica, gargalhando"27 (http://txt.jt.com.br/editorias/2007/01/26/var-1.94.12.20070 126.1.1.xml)

\subsection{Lexicalização do Item FORA}

Um processo de mudança que percorra o sentido contrário ao da abstratização excessiva capaz de fazer palavras ingressarem em classes de palavras menos gramaticais pode ser rotulado de lexicalização. Identificamos os seguintes padrões funcionais de lexicalização do item FORA no português:

FORA6 - integrada a um sintagma preposicionado, a palavra FORA advérbio é categoricamente subcategorizada por um verbo. No interior da expressão verbal, ela assume conotação mental, parafraseável por "não saber”, “desconhecer o assunto", embora também possa ser em, algumas situações, parafraseável por "não incluir", "não usar".

(31) Eu acho que o brasileiro tá por FORA do que é Brasil, sinceramente, tanta coisa acontece e ninguém, quer dizer, todo mundo se dá conta, mas ninguém procura é... se interessa, sabe? (Peul- r-4)

(32) Brinco muito com ele com a questão de quebra-cabeças e brinquedos lógicos, evito de brincar com ele com arma de fogo, com esses robô de arma de fogo, eu deixo de FORA, apesar que já vi que é meio difícil (inint). (Peul- r-7)

\footnotetext{
${ }^{26} \mathrm{O}$ exemplo foi colhido do Jornal da Tarde, pois não foram encontrados exemplos no corpus do PEUL que se encaixassem na definição exposta (http://txt.jt.com.br/editorias/2007/01/26/var1.94.12.20070126.1.1. xml)
} 
FORA7 - neste subconjunto de dados, apresenta-se vinculado a um sintagma preposicionado de caráter adverbial modal, em que a palavra FORA é advérbio categoricamente subordinado por um verbo. No interior da expressão verbal, FORA assume função comparativa, parafraseável por "de outro modo", "de modo nãoconvencional”.

(33) E: O almoço já está incluído na mensalidade ou é pago por FORA?(Peul- r-8)

(34) Por que que ele tem que ganhar por FORA pra poder trabalhar?(Peul- r-9)

FORA8 - Neste subconjunto, a palavra FORA é componente principal de um sintagma nominal indefinido.

(35) Mas, quando você está somente ficando, nada melhor que um bom FORA (tem que ser bem dado, claro) para acabar de vez com aquele namoro (ou ficada) que já não está legal. (http://www.terra.com.br/jovem/falaserio/2002/06/20/000.htm)

FORA9 - Anteriormente mostramos que a palavra AFORA poderia ter sido usada no século XVIII, em seu padrão funcional prepositivo. Nos dados contemporâneos, contudo, essa palavra somente aparece, embora tenhamos identificado alguns poucos dados, cristalizada no interior de uma expressão maior que pode ser estruturada da seguinte forma AÍ + $\boldsymbol{A F O R} \boldsymbol{A}^{28}$. Referimo-nos aos seguintes casos:

\footnotetext{
${ }^{27} \mathrm{O}$ exemplo foi colhido do Jornal da Tarde, pois não foram encontrados exemplos no corpus do PEUL que se encaixassem na definição exposta (http://txt.jt.com.br/editorias/2007/01/26/var-1.94.12.20070 126.1.1.xml )

${ }^{28}$ Esse uso deriva de um processo prévio de anteposição da preposição A, que confere ao item FORA o valor de movimento contínuo e direção incerta, sem ponto de chegada. Também cristalizou-se com a anteposição do dêitico aí. Observe a informação lexicográfica com base em Houaiss \& Villar (2001[0]): AFORA; Datação sXIII cf. IVPM Acepções — advérbio 1 para o lado de FORA, para o exterior, para FORA Ex.: saiu porta a. 2 continuamente, adiante, em frente (no tempo ou no espaço) Ex.: $<$ permaneceu alegre pela vida a.> < caminhou pela estrada a.> - preposição (sXIII) 3 exceto, salvo, FORA; com exclusão de Ex.: a. dois amigos, todos o abandonaram 4 além de Ex.: a. o conflito conjugal, ainda ficou desempregado Etimologia a prep. + FORA; f.hist. sXIV afFORA Sinônimos como prep.: ver sinonímia de exceto Antônimos como prep.: ver antonímia de exceto Homônimos AFORA (fl.AFORAr)
} 
(5) F- Ah... gostaria, sim. de viajar, ir à Europa, passear, não é? (est) Correr o-conhecer o mundo aí AFORA- isso no caso que o dinheiro desse.

E- A terra dos seus pais?

F- Também. Está aí. Também, (est) (Peul- c-11)

(36) a gente comemora sempre, não é? (risos) (rindo) Meu marido gosta de uma cervejinha... (est) (f) uns salgadinhos, então, é assim que a (est) gente comemora, não é? E os fogos por aí a FORA. (Peul- c-10)

Outra expressão cristalizada pode ser incluída nesse grupo, ainda que não tenha similar estrutura. Trata-se da expressão "de FORA a FORA", uma deturpação de "foz a FORA", conforme podemos depreender das expressões arroladas por Caldas Aulete (1970): “O boato já vai de foz em FORA”.

(37) O caminhoneiro Juliano Zardo diz que, no trecho paulista, a pista está com problemas. "É muito buraco, DE FORA A FORA da estrada." (http:// g1.globo.com/Noticias/Brasi1/0,,MUL303357-5598,00empresa+proibe+funcionários + de+viajar+pela+regis+bittencourt.html)

FORA10 - Casos há em que um verbo ou advérbio passe por um processo de substantivação ou adjetivação. São considerados à luz da gramática tradicional como casos de "derivação imprópria", por providenciarem recategorização ou conversão em outra classe de palavras. Esse tipo de recurso ganha evidência e espaço de análise na área de estilística:

(35) Mas, quando você está somente ficando, nada melhor que um bom FORA (tem que ser bem dado, claro) para acabar de vez com aquele namoro (ou ficada) que já não está legal. (http://www.terra.com.br/jovem/falaserio/2002/06/20/000.htm) 
(38) Desde que Débora soube que vai se apresentar na TV, a nojentinha tá se achando a estrela. É tanta piração que ela quer até evitar o contato com qualquer pessoa que seja um risco para sua carreira. Por isso, dá logo UM PASSA FORA em Pedro. (malhacao.globo.com/Novela/Malhação /0,AA1676829-4033,00)

Acreditamos que haja uma lacuna (apagamento), imperceptível aos ouvidos da geração contemporânea dada à alta freqüência de uso anterior. Explicamos: um item muito repetido passa a ser desnecessário em sua realização fônica, porque numa situação comunicativa o interlocutor já é capaz de inferir sua presença, mesmo em contextos em que ela foi apagada. Trata-se da bagagem pragmática a que se refere Dik (1987) e das pressões para uma comunicação eficiente.

Nas gerações seguintes, pode ocorrer o esquecimento histórico e a reanálise ativa-se. Alguns trabalhos, dentre os quais citamos Defendi (2008) e Lima-Hernandes (2008) relatam esse fenômeno no português com a reduplicação e com o continuum de mudança empreendido pela expressão "risco de perder a vida $>$ risco de vida $>$ risco de morte".

Entendemos que o exemplo (38) seja decorrente de uma formação modificada pela metonímia, dada à contigüidade sociofísica dos elementos e a uma proximidade que permite depreender a contigüidade na relação parte/todo.

Traugott \& König (1991, apud GONÇALVES, LIMA-HERNANDES \& CASSEB-GALVÃO, 2007:47), nesse sentido, afirmam que o reconhecimento de três instâncias permite a ocorrência do processo metonímico:

(i) a contigüidade na experiência sociofísica ou cultural;

(ii) a contigüidade com uma certa pessoa ou classe de pessoas;

(iii) a sinédoque ou contigüidade na relação parte pelo todo. 
FORA11- em alguns casos a palavra FORA sedimenta-se ao verbo que a antecede, ressemantizando-se como componente semântico da ação verbal descrita. Trata-se de um caso dúbio de análise entre os estudiosos da gramaticalização. Alguns afirmam que o resultado desse processo de mudança teria sido alvo de forte gramaticalização, redundando no surgimento de um verbo-suporte. Outros diriam que o fato de haver uma ressemantização de uma ação verbal garantiria a vinculação a um processo de lexicalização.

Em outras palavras, estamos afirmando que as mudanças lingüísticas manifestam-se por variados processos além do da gramaticalização. Um deles é o da lexicalização, vista aqui como oposição ao processo unidirecional da gramaticalização, ou seja, quando um morfema que é gramatical 'anda em sentido contrário no continuum' para se tornar uma unidade lexical. Também, podemos admitir a lexicalização como um processo de 'desgramaticalização'.

Se analisarmos os exemplos dos padrões funcionais visando à sua composição e à sua função, percebemos que nem sempre os resultados serão similares. Observemos casos, como trabalhar FORA e jogar FORA:

(39) F- Está. (riso) (ruídos)

E-("levando") O garoto direitinho. hein? E, me conta uma coisa. Quando você casar, você vai deixar (ruídos) a sua mulher trabalhar FORA ou não? (PEUL-c-1)

O eixo de distinção prototípico “dentro/FORA" se mantém nessa expressão, contudo não há uma recategorização gramatical da palavra sob análise. Ela é incorporada pelo verbo que a predicava como componente da ação verbal. 
Em uma visão mais ampla, há uma oposição de quem trabalha dentro de casa e o de quem trabalha FORA de casa, indicando aquele que sai de casa, se locomove, chegando a outro lugar, onde permanecerá por horas.

Com relação ao estatuto categorial do item analisado de forma isolada, poderíamos incluí-lo no subconjunto representado pelo padrão funcional 1, que reúne os adverbiais que marcam a oposição dentro/FORA. Entretanto, por ter passado por um processo de cristalização e absorção de seus traços na ação verbal descrita, este deve ser agrupado ao padrão funcional 11.

Podemos intuir que quando contribui de forma sedimentar com a nomeação da ação descrita pelo verbo, quando não pode sofrer mudança de ordem e quando não pode ser elidido do sintagma verbal sem prejuízo semântico à ação descrita, a palavra FORA, deve ser incluída na categoria dos verbos-suporte.

A respeito do verbo-suporte pouca informação se tem. Há, no entanto, alguns lingüistas que discutiram o assunto e deixaram inscritas algumas propriedades desses verbos:

1) O verbalizador ou verbo-suporte é aquele que, em uma construção complexa, reflete mero suporte de categorias e indica que o núcleo está no radical de seu complemento, ou seja, na palavra principal de em SN posposto ao verbo (BORBA, 1997)

2) Verbo-suporte pode ser analisado como um subtipo de verbo, às vezes quase esvaziado semanticamente, que se une a uma forma não-verbal, freqüentemente um SN que se torna o predicado da oração, constituindo o predicado complexo (verbo-suporte + $\mathrm{SN}$ ); então, o verbo suporte é a junção do verbo e do objeto direto (sintaticamente definido), ou do verbo e seu constituinte SN, que semanticamente o complementa (NEVES, 2006:63). 
Devemos ressaltar que o verbo-suporte tem grande componente discursivopragmático derivado dos usos em uma determinada sociedade. Reconhecer esse tipo de verbo em línguas mais antigas, em línguas estrangeiras, em dialetos com os quais não se tem grande intimidade pode gerar uma série de equívocos e incompreensões. 


\section{Capítulo IV}

\section{Checagem de Modelos Teóricos}

Passemos, agora, à explicitação dos modelos teóricos e ao exercício de checagem de seus encaminhamentos processuais à luz da análise dos padrões funcionais da palavra FORA.

\section{Modelo de Lehmann (1982)}

Medir graus e estágios da gramaticalização tem sido uma procura intensa entre os pesquisadores dessa linha de investigação. Um dos trabalhos que teve um eco formidável na comunidade de pesquisadores foi o de Lehmann (1982), que propôs três critérios para mensurar a gramaticalização, apoiado na idéia de autonomia do signo: 1 . peso (se autônomo, o signo deve ter peso); 2. coesão (se autônomo, o signo não estabelecerá relações com outros signos); e 3. variabilidade (se autônomo, o signo deterá alta mobilidade).

Para apresentar um modo de aplicar esses critérios em situações diferentes de uso, o autor relaciona esses três critérios com dois outros: a seleção (paradigma) e a combinação (sintagma) de signos:

$\begin{array}{llc}\text { ASPECTO } & \text { PARADIGMÁTICO } & \text { SINTAGMÁTICO } \\ \text { Peso } & \text { Integridade } & \text { Escopo } \\ \text { Coesão } & \text { Paradigmaticidade } & \text { Conexidade } \\ \text { Variabilidade } & \text { Variabilidade paradigmática } & \text { Variabilidade sintagmática }\end{array}$

Esse conjunto de seis parâmetros representa as propriedades variáveis dos signos. Visa, em combinação, à avaliação da autonomia, prestando-se, por conseguinte, 
à medição da gramaticalização. Explicamos: o decréscimo do peso e da variabilidade e o aumento da coesão são os três aspectos que remetem à gramaticalização.

O peso é dividido em sintagmático (potencial combinatório do signo) e paradigmático (aspecto de seleção do signo). O primeiro refere-se ao conteúdo semântico e fonológico de uma palavra; é representante do tamanho da palavra, de sua estrutura. O segundo é referente à quantidade de construções em que essa palavra é aceita. Coesão paradigmática refere-se à integração no paradigma e a segunda é referente ao seu ajuste com outras palavras. Variabilidade paradigmática refere-se à escolha de outras formas que se encaixem no mesmo paradigma da palavra em análise; a sintagmática diz respeito à posição ocupada pela palavra.

Em se tratando da intensidade do processo de gramaticalização, Lehmann afirma que alguns critérios podem auxiliar no reconhecimento, como os em destaque na tabela:

\begin{tabular}{|l|l|l|l|}
\hline Parâmetro & Gramaticalização Fraca & Processo & Gramaticalização Forte \\
\hline Integridade & $\begin{array}{l}\text { Feixe de traços semânticos: } \\
\text { Conjunto de propriedades } \\
\text { semânticas possivelmente } \\
\text { polissilábicas }\end{array}$ & Desgaste/ atrição & $\begin{array}{l}\text { Poucas propriedades } \\
\text { semânticas: } \\
\text { monosegmental }\end{array}$ \\
\hline Paradigmaticidade & $\begin{array}{l}\text { O item participa } \\
\text { escassamente/levemente no } \\
\text { campo semântico }\end{array}$ & $\begin{array}{l}\text { Paradigmaticidade- } \\
\text { organização em } \\
\text { paradigmas }\end{array}$ & $\begin{array}{l}\text { Fortemente integrado no } \\
\text { paradigma }\end{array}$ \\
\hline $\begin{array}{l}\text { Variabilidade } \\
\text { paradigmática }\end{array}$ & $\begin{array}{l}\text { Livre escolha de itens, mas } \\
\text { dependentes das intenções de } \\
\text { comunicação. }\end{array}$ & Obrigatoriedade & $\begin{array}{l}\text { Escolha sistematicamente } \\
\text { estrita, uso obrigatório. }\end{array}$ \\
\hline Escopo & $\begin{array}{l}\text { O item as correlaciona com } \\
\text { constituintes de } \\
\text { complexidade arbitrária }\end{array}$ & $\begin{array}{l}\text { Condensação: } \\
\text { encurtamento das formas }\end{array}$ & $\begin{array}{l}\text { O item modifica palavra } \\
\text { ou estema (raiz) }\end{array}$ \\
\hline Coesão & $\begin{array}{l}\text { O item é justaposto } \\
\text { independentemente }\end{array}$ & $\begin{array}{l}\text { Coalescência/ } \\
\text { Aglutinação: formas } \\
\text { adjacentes se aglutinam }\end{array}$ & $\begin{array}{l}\text { O item é afixo ou até } \\
\text { mesmo suporte de traço } \\
\text { fonológico }\end{array}$ \\
\hline $\begin{array}{l}\text { Variabilidade } \\
\text { sintagmática }\end{array}$ & $\begin{array}{l}\text { Mobilidade do item } \\
\text { livremente nas estruturas } \\
\text { linearmente livres se } \\
\text { tornam mais fixas }\end{array}$ & $\begin{array}{l}\text { O item ocupa posição } \\
\text { fixa. }\end{array}$ \\
\hline Direção doprocesso & \multicolumn{2}{|l}{} \\
\hline
\end{tabular}

Os exemplos a seguir referem-se à demonstração da aplicabilidade dos parâmetros de Lehmann (1982). 
Integridade é um critério em que o conjunto de traços assegura a identidade de um item; quanto menos propriedades semânticas, mais gramaticalizado o item se mostra. No exemplo (40), a presença do advérbio FORA é imprescindível para que a idéia pensada pelo interlocutor seja expressa eficientemente ao outro interlocutor. Sair não equivale a sair FORA. O item sob análise não detém a autonomia e propriedades semânticas do item-fonte FORA, portanto mais gramaticalizado ele é nessa função.

(40) Subimos no Santo Cristo, a primeira vez ele pulou a janela, saiu FORA. A segunda vez que a gente foi lá, aí eu subi por trás do morro, o tenente veio pela frente do prédio dele, quando ele viu o tenente, ele pulou a janela. (Peul-c-15)

Nos exemplos que se seguem encontramos o critério da paradigmaticidade que é a integração da forma e semântica em um paradigma delimitado, observamos que a gramaticalização é leve, pois o item FORA tem maior flexibilidade para ampliar seu escopo no campo semântico, como no exemplo (40) acima, havendo a possibilidade de exclusão da palavra FORA.

No exemplo (41), o item FORA adquire maior rigidez dentro do paradigma, impossibilitando sua exclusão:

(41) Eu fiquei assim ... achei estranho, né? num esperava assim o grau de violência que lá tem, entendeu? eh ... porque ó, eu fui no carnabelô que ... é carnaval FORA da época, né? (Peul-r-3)

A variabilidade paradigmática é a que se refere à liberdade de escolha de uma outra palavra que poderia ser usada no lugar daquela que o falante escolheu. No exemplo abaixo, o viver FORA poderia ser substituído pelo viver no exterior. A despeito disso, não é comum encontrarmos a segunda expressão nos dados estudados:

(42) E- Você conhecer [tudo]- tudo que (inint)ganhar muito! [(inint)] F- [pois é! Tinha] que ganhar sozinha, não é? Sozinha. (rindo) 
E- Tem algum país assim que te interessa mais?

F- Ah! Tem vários! sabe? Tem vários países. (hes) Tinha loucura para conhecer. Para só ir assim passear sabe? (est)

F- Conhecer. Como é que é, como é que eles vivem lá FORA. Sabe? A maneira deles se portarem, sabe? Tudo isso! (Peul-c-5).

Em relação à coesão, nota-se a complexidade na estrutura da construção a que a forma vincula-se. No exemplo (43), o item é incorporado pelo verbo para denotar uma ação específica, cristalizando-se o verbo-suporte:

(43) F: Corre. Até hoje ele (inint) "ah, vocês erraram no molequinho também erraram. Aonde me vê, oh (estala os dedos) "sarta" FORA. Aí ficou aquele negócio de resistro do neném, resistra, não resistra, resistra não resistra, eu falei: "Suele, você qué que eu resistro?" Que eu ía resistra o menino. Ela: “Ah, mãe resistra.” Aí depois eu pensei bem, falei: “ah, não. Vou tirá a responsabilidade das costa dela, falei: "não. Não, vai você e resistra." Aí mandei ela chamá o pai dela, fiquei com o neném ela foi lá no cartório e resistrou o neném.

É interessante que o verbo-suporte deveria atender aos critérios de fraquíssima gramaticalização, por se tratar de ressemantização verbal. No entanto, ele obedece a critérios que denunciam forte gramaticalização. Estariam os verbos-suporte em gramaticalização intensa formal e a lexicalização intensa sob o ponto de vista semântico? Seria possível reconhecer estatutos diferentes a partir do processo de mudança especificado? Algumas respostas aos testes nos dizem que sim, pelo menos no que se refere aos critérios de Lehmann, que favorecem a medição de gramaticalizações já em estágio avançado.

Submetendo os padrões funcionais ao modelo de Lehmann, percebemos que nem tudo se encaixa perfeitamente. Notamos que esses critérios não necessariamente são aplicáveis à seqüência imposta pela verticalidade do quadro, pois, tomando como 
alvo de análise a palavra FORA, intuímos que o deslizamento funcional empreendido possa ser representado somente em algumas das linhas horizontais, por exemplo, a gramaticalização forte é formada por poucas propriedades semânticas, ela também está fortemente integrada no paradigma, esses fatores não ocorrem no exemplo:

(35) Mas, quando você está somente ficando, nada melhor que um bom FORA (tem que ser bem dado, claro) para acabar de vez com aquele namoro (ou ficada) que já não está legal. (http://www.terra.com.br/jovem/falaserio/2002/06/20/000.htm)

Aqui a escolha feita pelo falante é obrigatória para o entendimento da comunicação, o FORA não modifica palavras e sim é modificado por elas (um e bom), neste exemplo a palavra em análise não possui afixo, mas ocupa uma posição fixa no paradigma. Portanto não segue todos os padrões de gramaticalização propostos por Lehmann (1991), o que pode dar abertura à idéia de que, nesta palavra em específico, a unidirecionalidade no processo de gramaticalização não ocorre continuamente.

Os parâmetros, fatores ou critérios que Lehmann (1991) apresenta são observados como 'tendências' por Hopper (1991 apud NEVES, 1997:126) que reconhece que os princípios de Lehmann são relevantes para palavras/itens fortemente gramaticalizados e também para estudos sobre a tipologia lingüística, mas considera que outros critérios seriam necessários para a avaliação de gramaticalização incipiente.

\section{Modelo de Hopper (1991)}

Outro trabalho que demonstrou a preocupação com a medição da gramaticalização foi aquele produzido por Hopper (1991). Sua justificativa para não aceitar de imediato os critérios de Lehmann é calcada justamente no grau de gramaticalização da palavra sob análise. 
Segundo Hopper, seus princípios se prestam a avaliar fenômenos em estágios muito recentes de gramaticalização, o que, ainda segundo o autor, não é possível se adotarmos os critérios de Lehmann. Propõe, então, cinco princípios de gramaticalização, que, em seu próprio texto, também são chamados de estágios de gramaticalização, a despeito das implicações para a adoção de um ou outro rótulo:

1.Estratificação - surgimento de novas formas dentro de um mesmo domínio funcional, fazendo com que novas camadas emerjam continuamente. $O$ resultado dessa estratificação é a coexistência de formas antigas com as camadas mais novas.

2. Divergência - conseqüência da estratificação, reflete o momento em que uma forma lexical, em gramaticalização, gera novas formas mais gramaticais, que passam a se comportar como as da nova categoria e não mais como a categoria de onde proveio.

3. Especialização - a obrigatoriedade do uso do item gramaticalizado passa a ser realidade, especialmente se seu sentido for mais geral, daí a alta freqüência.

4.Persistência - Depois de ser gramaticalizado, o item ou termo ainda carrega sinais de seu significado original antes de se gramaticalizar.

5.Decategorização - em processo de gramaticalização, os itens/formas perdem ou neutralizam marcas morfológicas e categorias sintáticas; portanto, os itens lexicais/concretos de substantivo, verbo e advérbio se tornam itens gramaticais/abstratos como preposição.

A gramaticalização não implica a eliminação ou a substituição de formas, porém traz 'um 'amontoamento' do campo com formas sutilmente diferenciadas, todas tendo aproximadamente o mesmo sentido" (HOPPER, 1996:230 apud LIMA-HERNANDES, 2005).

Nem todas as expressões lingüísticas são marcadas por todas as características do processo de gramaticalização, mas, com certeza, alguma(s) dela(s) podem servir de 
parâmetro para a observação dos mecanismos adotados pelo sistema da língua para proporcionar a mudança de estatuto.

Os estudos que avaliam a atuação desses princípios discutem a pertinência de se utilizar o rótulo princípios em contraposição a estágios, a exemplo de Ferreira (2007), que foi categórica ao afirmar que não se pode falar em princípios, uma vez que nem todos ocorrerão a depender do grau de gramaticalização em que se encontrem. Analisemos, então, os dados à luz dos estágios de Hopper:

a) Estratificação - a palavra FORA, ampliando suas funções, que muitas vezes podem redundar em recategorizações, é paradigmatizada em outras listas de palavras. Passa, em conseqüência, a integrar outras regras variáveis. No caso de FORA preposicional, há a concorrência com a palavra exceto, como ilustrado no exemplo seguinte:

(44) eu realmente fiquei decepcionada, eu pensei que fosse uma coisa assim mais tranqüila, mas FORA isso a cidade é muito linda, o povo é muito simpático, muito receptivo, acho que até mais do que o carioca porque o carioca é meio desconfiado. (Peul- r-3)

(44a) ... mas exceto isso a cidade é muito linda, o povo é muito simpático...

b) Divergência - a base é um item-fonte que mantém a forma e 'duplica' a função, com afastamento de comportamento funcional entre o item-fonte e o item-meta. Assim, o item FORA advérbio recategoriza-se como preposição: FORA [advérbio] $\rightarrow$ FORA [preposição]: além $>$ FORA / exceto $>$ FORA.

(45) Tais fenômenos, FORA de sua obviedade, ocultavam um poder divino (...)(MASSI, MLG-Tese) (2001:9)

(45a) Tais fenômenos, além/exceto de sua obviedade, ocultavam um poder divino... 
(30) Não perca esta chance, cadastre-se agora mesmo em um dos nossos e-mails. Lembrando que todos eles tem a garantia de que ninguém (FORA você mesmo) estará lendo o seu e-mail, ou seja, você terá privacidade total. http://orbita.starmedia.com/frasez/seuemail.htm

(30a) ...todos eles têm a garantia de que ninguém (exceto você mesmo) estará lendo o seu email....

c) Especialização - Em alguns domínios funcionais, a palavra passa a ser empregada de forma obrigatória. É o que vemos com FORA preposicional, que tem se tornado freqüencialmente superior aos demais padrões funcionais.

(7) FORA preposicional $\rightarrow$ exceto: Há tempo venho falando que o SPFC neste ano (FORA um ou dois jogos) não vem correspondendo com um bom futebol. Isso até certo ponto é normal pois perdemos peças fundamentais de conquistas recentes, como Danilo, Mineiro e Fabão. (http://www.saopaulofc.com.br/articles.php?id=576)

(46) FORA preposicional $\rightarrow$ além: (...) aquelas que um deus usufrui FORA do domínio sagrado. (MASSI, MLG-Tese) (2001:p120-rodapé)

d) Persistência - Depois de ser gramaticalizada, a palavra FORA ainda traz sinais de significado da palavra/item original, no caso seu valor etimológico de oposição interior/exterior. Mesmo recategorizada como preposição, seu valor etimológico de "ausência" permite a reanálise da palavra com interpretação de exceção.

(47) Mas aquele que, persuadido pelos pássaros de tais palavras quiser, estando FORA da razão, explorar nossa profecia(...)(MASSI, MLG-Tese)

e) Decategorização - um advérbio é uma classe de palavra invariável, assim, será decategorizado para outra classe mais abstrata ainda, como é o caso da preposição.

(48) (advérbio locativo) $\rightarrow$ São oito hora de serviço. Agora, (hes) nesse tempo das oito até meio-dia, aí, eu saio e vejo as coisa lá FORA- porque é bom o cara sair, 
tem [que]- que esfriar a cabeça, aí, eu saio, eu vou para o cinema, [quando]quando estou [com]- com dinheiro, não é? (Peul-c-19)

(49) (preposição) $\rightarrow$ F- [Ah!] Meu irmão, certo? Meu irmão é muito bacana, um padre maravilhoso, certo? Se ordenou tem cinco anos, Jaragu, primeira missa dele foi em Magalhães Bastos, é o primeiro padre aqui de Magalhães Bastos, celebrou a primeira missa aqui em Magalhães mesmo. Na primeira missa dele, eu tive a honra- ele fez a primeira comunhão da minha filha, certo? Pois é. FORA de serie. muito bacana. (f) E o meu irmão, ultimamente, ele agora é cantor também. além de ser padre é cantor. É. Tem disco gravado. (est) é. Que ficou quatro ano em ("garfanha") de Nazaré como vigário. Agora está em Jaragu. ("Um") padre excelente todo mundo gosta do meu irmão. Muito bacana, mas bacana mesmo. Não é conversa não. Meu irmão é FORA de série.(Peul-c-7)

No continuum, percebemos a mudança categorial, mas nos perguntamos se a classe de palavras seria o melhor caminho para se apreender a gramaticalização de um item, pois muitas vezes notamos um deslizamento funcional que não implica mudança de classe de palavras. Observemos o seguinte quadro:

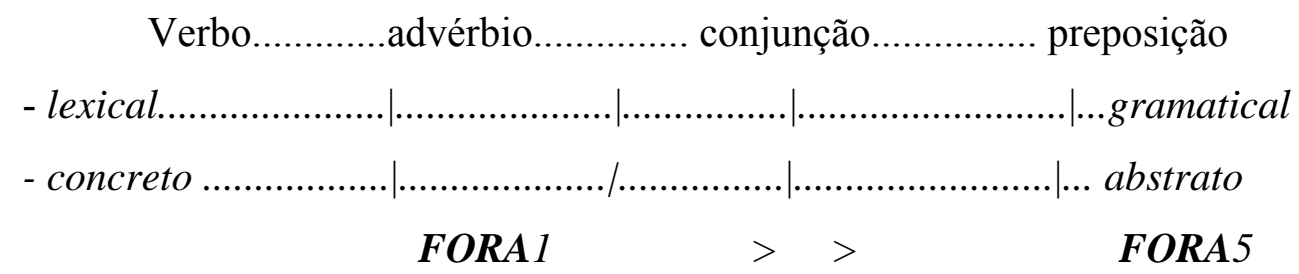

Somente em duas classes de palavras já notamos uma forte gramaticalização, mas sabemos, pela análise feita, que os deslizamentos operados entre advérbio > preposição geram maior número de padrões funcionais do que esses dois representados pelas classes de palavras. 


\section{Modelo de Heine, Claudi \& Hünnemeyer (1991)}

Para que haja gramaticalização, Heine, Claudi \& Hünnemeyer (1991) explicam que uma direção deve ser reconhecida num deslizamento entre as categorias cognitivas, que refletiriam um deslizamento gramatical: do menos gramatical para o mais gramatical. Eis o grande pilar e, ao mesmo tempo, a grande polêmica dos estudos sobre gramaticalização.

Os autores oferecem sete tópicos que determinam as condições em que as categorias gramaticais se tornam mais gramaticalizadas:

(a) se ela for, etimologicamente, derivada da outra: como afirmam os lexicógrafos, a palavra FORA inicia sua trajetória no português do século XIII como um advérbio passando a AFORA, e voltando a ser FORA, mas como preposição:

\section{FORA advérbio:}

(1) F: [ Acho que aqui FORA é melhor prá se trabalha] do que funcionário público, funcionário público tem que manda. Veja bem meu caso na área de educação (Peulr-9)

\section{$\underline{\text { AFORA advérbio }}$}

(5) F- Ah. gostaria, sim. de viajar, ir à Europa, passear, não é? (est) Correr o-conhecer o mundo aí AFORA- is so no caso que o dinheiro desse.

E- A terra dos seus pais?

F- Também. Está aí. Também, (est) (Peul- c-11)

\section{FORA preposição:}

(2) E: Ah, é ? E faz muito tempo que você mora aqui em Campo Grande?

F: Faz, uns vinte anos.

E: Ah, é ? Ah... sim. É... você já morou em outros lugares ? (Est) FORA o Aterro onde você nasceu...

F: Irajá e Anchieta. (Peul-r-adri) 
(b) se duas funções de caso diferem apenas quanto ao fato de que uma tem uma função espacial e outra não, então a última é mais gramaticalizada.

\section{Função espacial:}

(50) Olha, eu não tenho base certa, porque eu nasci aqui, mas eu saí, vivi FORA aí por Madureira, Campo Grande e Botafogo. Até em Caxias, eu já morei. Aliás falar em outro Estado, Caxias já não é mais Rio de Janeiro, não é? (Peul-c-3)

\section{Função locativa:}

(51) Exatamente, então fica difícil saí, í ao cinema, pra saí lá FORA pra í a uma pizzaria, pagá estacionamento, gasolina, então isso tudo gasta, então entre gastá e economizá um pouquinho e terminá a minha obra, eu prefiro economizá, nem que fique em casa final de semana, ali no... no outro terracinho, tirano, veno a noite, o luar, muito bom (risos e) que eu... (Peul-r-12)

(c) se duas categorias gramaticais diferem pelo fato de que uma implica um participante humano e outra, inanimado; então, a última é mais gramaticalizada.

(+ humano; + animado)

(52) ( ) Em síntese, quer dizer: se você se casar você se casando, a sua mulher não vai trabalhar FORA? (Peul-c-2)

(- humano; - animado)

(2) E: Ah, é ? E faz muito tempo que você mora aqui em Campo Grande? F: Faz, uns vinte anos. E: Ah, é ? Ah... sim. É... você já morou em outros lugares ? (Est) FORA o Aterro onde você nasceu... F: Irajá e Anchieta. (Peul-r-adri) 
(d) uma categoria referente a um conceito com três dimensões é menos gramaticalizada do que uma ligada a um conceito de uma dimensão.

$\underline{\text { FORA - advérbio (lugar- físico) }}$

(53) É mais não fui. Eu dei aula aqui em casa só sabe? Depois que... casada tudo... meu filho novo ainda tava até na faculdade. Eu dei aula, primeiro eu cosi muito pra FORA, fui costureira. (Peul-r-13)

$\underline{\text { FORA - advérbio (lugar- mental } \rightarrow \text { abandonar) }}$

(54) eu sei que o bolo é às cinco, eu (ruído) saí FORA, não fiquei! (Peul-r-10)

$\underline{\text { FORA - advérbio (lugar- mental } \rightarrow \text { de outro modo/não convencional) }}$

(55) E: [ est 56] Aí você paga por FORA?

F: Pago por FORA todo mês eu pago cento e quinze, manda depositá aí eu levo no banco e pago. (Peul-r-9)

\section{$\underline{\text { FORA - preposição }}$}

(56) E: Que lugar do Brasil você gostaria de conhecer?

F: A Bahia.

E: E FORA do Brasil?

F: Nenhum. Lugar frio, guerra, não. Prefiro ficar por aqui mesmo (Peul-r-8)

(e) se duas categorias diferem pelo fato de que uma expressa uma 'relação temporal' e a outra, uma 'relação lógica', então, a última é mais gramaticalizada: assim, 'causa' e ‘condição’ são mais gramaticalizadas do que 'tempo'.

Aplicando-se ao advérbio FORA, há uma categoria que indica lugar e outra que indica lógica, ou seja, o FORA QUE. 
Todos os demais padrões funcionais que indicam circunstâncias são, então, menos gramaticalizados do que os padrões funcionais mais abstratizados e recategorizados como preposições e conjunções. Operadores argumentativos são mais gramaticalizados do que advérbios circunstanciais, portanto.

(f) se duas categorias diferem porque uma é mais abrangente, a mais abrangente é mais gramaticalizada; assim, 'modo' é mais gramaticalizado do que 'instrumento'.

Esse critério nos ajuda a compreender o grau de gramaticalização dos padrões funcionais de FORA, uma vez que a circunstância indicativa de "espaço físico" nos parece menos abrangente do que a marcação de exceção em qualquer tipo de evento, função desempenhada pela preposição e operadores argumentativos.

\section{FORA advérbio:}

(1) F: [ Acho que aqui FORA é melhor prá se trabalha] do que funcionário público, funcionário público tem que manda. Veja bem meu caso na área de educação (Peulr-9)

\section{FORA preposição:}

(2) E: Ah, é ? Ah... sim. É... você já morou em outros lugares ? (Est) FORA o Aterro onde você nasceu...

F: Irajá e Anchieta. (Peul-r-adri)

(g) se um dado morfema governa tanto sintagmas nominais como sentenças, então, o último uso é mais gramaticalizado do que o anterior.

O escopo do advérbio FORA é um verbo, o que não ocorre com a preposição FORA que rege em alguns casos uma oração, especialmente com a introdução do operador argumentativo FORA que, que introduz idéias, independentemente de seu tamanho. 
Pela teoria de Heine, Claudi \& Hünnemeyer (1991), encontramos indícios, em forma de adequação da teoria aos exemplos, que as categorias sofrem graus de gramaticalização, mas notamos que esses graus estão ligados ao princípio da unidirecionalidade, que é freqüentemente associado à organização concreto $>$ abstrato das categorias cognitivas, como nos exemplos de FORA locativo físico para mental.

Assim, o surgimento de novas expressões lingüísticas através de estratégias que ampliam o uso já existente dessa expressão lingüística no sistema da língua tem sido demonstrado por meio da movimentação das categorias cognitivas. A organização proposta por Heine, Claudi \& Hünnemeyer (1991) é a seguinte:

PESSOA $>$ OBJETO $>$ ATIVIDADE $>$ ESPAÇO $>$ TEMPO $>$ QUALIDADE.

A abstratização pode ser lida da esquerda para a direita, que também equivale à organização das categorias mais próximas do indivíduo (falante), as mais concretas, para as mais distantes e [-concretas].

Se entre as categorias houver a possibilidade de existência de outra categoria, então elas são consideradas categorias 'fortes'. Da mesma forma, as expressões lingüísticas podem receber influência de mais de uma categoria cognitiva; palavras lexicais ou gramaticais só poderão ampliar seu significado e sua função mudando de posição para menos lexicais e mais gramaticais.

Essa avaliação da organização unidirecional, conforme os padrões funcionais anteriormente apresentados, é uma das estratégias de que lançaremos mão como recurso de análise, tal como defende Braga (mimeo., apud GONÇALVES, LIMAHERNANDES \& CASSEB-GALVÃO, 2007:41): “um recurso analítico que permite 
organizar e melhor compreender os diversos usos associados a uma determinada forma".

Tendo em vista que as estruturas de uma língua estão em constante movimento, não há como 'engessar' a gramática de uma língua nem mesmo como recurso pedagógico, pois a língua é acometida de mudanças lingüísticas inevitáveis, como a que analisamos nesta dissertação, o processo de gramaticalização de um item originariamente adverbial.

Percebemos que os padrões funcionais não são homogêneos em relação à forma e função entre cada padrão e seus respectivos exemplos. Então, buscamos uma explicação associada à mente humana no momento prévio ao da formação da cadeia sonora, ou seja, no universo pré-verbal, nos segundos que antecedem a fala. Essa estratégia favorece que tomemos contato a representação do universo real do falante (universo impregnado das ideologias continentes na sociedade que ele integra), como explica Sweetser (1997:4):

It should not be a controversial claim that relationships between linguistic form and function reflect human conceptual structure and general principles of cognitive organization ${ }^{29}$.

Daí a separação dos exemplos em categorias cognitivas que partem da pessoa (o falante) para o objeto ao qual o falante se refere e deste para o espaço em que a ação ocorre para somente depois passar ao tempo em que essa mesma ação ocorre.

Os padrões representados pelos deslizamentos funcionais da palavra FORA denotam uma abstratização que parte de espaço > qualidade. Às vezes, também fomos

\footnotetext{
${ }^{29}$ Nossa tradução: "Não deveria ser um tema controverso que as relações entre a forma e função lingüísticas refletem a estrutura humana conceitual e os princípios de organização cognitiva".
} 
surpreendidos por dados que não migravam de uma categoria cognitiva a outra, mas simplesmente mudavam o plano de concreto para abstrato numa mesma categoria.

No caso de 'aqui FORA é melhor prá se trabalhar do que funcionário público (...)', o falante emprega o item FORA como excludente de local de trabalho (funcionário público oposto à área da educação) para especificar sua posição no contexto, ele se posiciona como aquele que trabalha com a educação ao utilizar o advérbio 'aqui'. Então a distância entre lá/aqui e dentro/FORA demonstra um processo que era físico (locativo) e se tornou mental. Mais além, no contexto, subentende-se que o falante se opõe ao 'lá dentro', ou seja, no trabalho como funcionário público.

Nos contextos em que apresenta-se acompanhado do advérbio "lá", "aqui" e "aí", o item FORA indica uma abstratização da categoria de espaço, pois o falante parte do espaço físico para o mental.

\section{Modelo de Castilho (2006)}

Nos momentos anteriores, revisitamos as teorias de Lehmann (1982), de Hopper e de Heine, Claudi \& Hünnemeyer (1991) para testarmos a eficiência de seus critérios para medir o grau de gramaticalização da palavra FORA em seus variados padrões funcionais. Esses autores demonstram vincular-se ao modelo clássico da gramaticalização, especialmente porque partem de um domínio lexical para atingir um domínio gramatical, cujo processo de deslizamento intitula-se gramaticalização, haja vistas que esvazia-se o léxico e preenche-se a gramática ou, ainda, há perdas de conteúdo e mudança de categoria gramatical. 
Castilho (2006) explica que, na Teoria Multissistêmica, a palavra não tem obrigatoriedade e nem plenas evidências de iniciar o seu processo de variação pelo léxico, construindo a premissa de que a palavra não surge de domínios estanques, ela surge do entrelaçamento dos domínios (lexical, semântico, gramatical e discursivo) por meio dos princípios sociocognitivos da ativação, reativação e desativação.

Esses princípios tomam forma para suprir as necessidades existentes no ínterim do pensamento até o ato da fala para que ocorra a compreensão do enunciado do falante, ou seja, a negociação conversacional que pode culminar ou não com a manutenção do turno tendo em vista as necessidades de intercompreensão.

Essa é a razão para que o entendimento da formação pré-verbal do processo seja investigada em seus produtos - palavras -, que pertencem a um domínio e se modificam, de alguma forma, assumindo características novas. Abrem-se, assim, discussões sobre as variações reincidentes no Português Falado (PF), analisáveis a partir do corpus desta pesquisa.

Iniciaremos, então, a checagem do modelo de Castilho, que se apresenta segmentado em subsistemas lingüísticos, que devem ser avaliados quanto à atuação dos princípios de ativação, desativação e reativação. Como forma de ilustração, recorreremos a exemplos já citados.

\subsection{Lexicalização}

Há, no domínio da Lexicalização, a formação de itens por vias etimológicas e neológicas, embora também possam ocorrer derivações e empréstimos. Torna-se, 
assim, necessário estudar a forma pela qual cada um dos padrões analisados ingressou na língua portuguesa.

Etimologicamente, o advérbio $\boldsymbol{F O R} \boldsymbol{A}^{30}$ origina-se no Latim em "FORAS" e identificava um espaço físico, tal como registrado em Ernout \& Meillet (1951). As acepções que se desenvolvem se vinculam a essa base etimológica:

\section{(i) Exteriormente, na face externa:}

(6) Olha, brincava-se muito de roda e - aquele grupinho, não é? (Está) e <ti...>podia brincar aí FORA, à noite. (Peul-c-10)

(57) Ele: "Ah! Pode deixar minha filha!" ele ficava em cima do portão, para o lado de dentro. Porque, se ele ficasse do lado de FORA, o- era capaz do carro pegar ele ali. Uma vez, de manhã, eu estava saindo para ir na padaria, que eu tinha que ir com meus filho no médico, eu estava atrasada, estava saindo, quase que o caminhão me pega.( Peul-c-4)

(ii) Em lugar diferente do da residência habitual:

(58) almoça FORA- Só final de semana que eu faço alguma coisa pra gente comê ou a gente almoça FORA, tudo na rua, passa o tempo todo na rua.( Peul-r-1)

(59) E- Muita fralda para lavar, não é?

F- Ah, meu Deus do Céu! Antigamente não tinha essas fraldas descartáveis, essas fraldas que bota, joga FORA. Eu vejo a minha sobrinha lá, com o filho dela. sujou, $<$ chi $>$, lixo.

E- Bem mais prático.

F- Muito mais, não é. (riso f) (Peul-c-11)

\footnotetext{
${ }^{30}$ Excluímos dessa análise os casos em que FORA atua como elemento de composição de substantivos no português, justamente porque, segundo Houaiss e Villar (2001), sua etimologia seria diversa da primeira apresentada: de origem grega "phorá" codifica 'ação de levar, de carregar à frente' (conexo com o v. phéró 'levar, carregar'), e ingressa na terminologia científica da língua portuguesa em fins do séc. XIX . É um caso típico de homonímia.
} 
(60) [Não, não, para mim não teria problema, se ela conseguisse um emprego, que o emprego desse para pagar uma boa empregada, cuidar bem do meus filho, manter tudo conforme ela vem mantendo, tudo bem, agora, para conseguir um emprego, para ganhar um salário mínimo, eu pagar um salário mínimo à empregada para minha mulher ficar batendo perna na rua, (barulho de moto) não é interessante, certo? só para dizer que está empregada, para dizer que está trabalhando FORA, em vez de estar ajudando o marido, está prejudicando, não é interessante. e hoje em dia emprego de cem mil cruzeiro não está fácil de arranjar, certo? (Peul- c-7)

(iii) Longa distância:

(50) Olha, eu não tenho base certa, porque eu nasci aqui, mas eu saí, vivi FORA aí por Madureira, Campo Grande e Botafogo. Até em Caxias, eu já morei. Aliás falar em outro Estado, Caxias já não é mais Rio de Janeiro, não é? (PEUL c3)

(iv) Em país estranho:

(61) “Assim- mas poxa! Queria conhecer tudo lá FORA, sabe? Um montão de lugares. Mas, (inint) um sonho muito alto. Mas que eu tinha vontade de conhecer FORA, tinha. não é?" (Peul-c-5)

Sua base etimológica provê condições para que assuma outras funções sintáticas no decorrer dos séculos:

\section{(v) Exceto, menos:}

(2) E: Ah, é ? E faz muito tempo que você mora aqui em Campo Grande ?

F: Faz, uns vinte anos.

E: Ah, é ? Ah... sim. É... você já morou em outros lugares ? (Est) FORA o Aterro onde você nasceu..

F: Irajá e Anchieta. (Peul-r-adri) 
(vi) Afastado de:

(18) Sou uma mulher, sei lá! FORA de série, sabe? (PEUL c12)

(35) Mas, quando você está somente ficando, nada melhor que um bom FORA (tem que ser bem dado, claro) para acabar de vez com aquele namoro (ou ficada) que já não está legal. (http://www.terra.com.br/jovem/falaserio/2002/06/20/000.htm)

(vii) Além de:

(62) Sabe? Mas num vou FORA disso, eu não vou na igreja domingo à missa eu não vou. Eu fiz comunhão, casei na igreja, tudo, mas... (PEUL r14)

Essa mesma palavra pode se unir à preposição 'a', constituinte da palavra AFORA, como, no exemplo:

(5) Ah, gostaria, sim, de viajar, ir à Europa, passear, não é? (est) Correr o- conhecer o mundo aí AFORA- isso no caso que o dinheiro desse. (Peul-c-11)

Com esta análise, pudemos observar a origem dos itens e, doravante, suas mudanças em diversos níveis os quais serão explicitados a partir dos demais subsistemas. Entretanto, convém lembrar que subsistemas são autônomos, sem hierarquia nem derivação entre eles e a seqüência aqui apresentada é aleatória. 


\subsection{Semanticização}

Segundo Svorou (1993:06) afirma, há três dimensões interligadas durante a enunciação: local da ação com participantes, suas características e tempo de duração da ação:

In our everyday interactions we talk about situations locating them in space. The locus of situations together with the participants and their characteristics, and the time during which they occur constitute the three dimensions along which we understand and talk about them. (...) Each of the expressions carries a different degree of explicitness in the encoding of referents in the world ${ }^{31}$.

São informações básicas necessárias a toda a comunicação, as quais contribuem, naturalmente, para a construção do sentido dos itens empregados no momento interativo.

Para compreender o processo semântico - a semanticização - não se pode perder de vista de que para a construção de sentido de cada um dos itens contribuem as categorias cognitivas de base. Essas são analisáveis pelas derivadas, que apresentam subcategorias e, por fim, traços e papéis semânticos relevantes.

\footnotetext{
${ }^{31}$ Svorou, em seu livro The grammar of space (1993), explica que "Em nossas interações diárias, falamos sobre situações localizando-as no espaço. O locus dessas situações (dimensão 1), com os participantes (dimensão 2) juntamente do tempo em que ocorrem as situações (dimensão 3), constituem as três dimensões com as quais formamos o entendimento quando na interação verbal. "(...) Cada uma das expressões carrega um grau diferente de clareza na codificação dos referentes no mundo".
} 
a) Semanticização da palavra FORA

Em todos os empregos desse advérbio, por aproximação metafórica, a etimologia persiste, passando a sinalizar exceção, uma oposição interno/externa mais abstratizada. Em alguns casos, torna-se praticamente imperceptível o traço etimológico em algum novo uso, mas, se atentarmos para o contexto de emprego, não será difícil identificá-lo. No caso do advérbio FORA, que inicia sua trajetória vinculando o sentido comunicativo ao local delimitador do espaço dentro/FORA. A perspectiva, então, se torna relevante na situação comunicativa.

\section{$\underline{\text { Perspectiva no espaço }}$}

Eixo externo: em todos os exemplos, de modo mais nítido, a oposição básica de espaço físico: lado interno / lado externo é colocada em foco para o interlocutor, que deve fixar sua perspectiva neste último em relação a um determinado e claro espaço físico. A informação relativa a esse espaço físico é compartilhada (de modo preciso ou vago) pelos interlocutores.

De modo preciso, o falante explicita que FORA tem seu valor dêitico opositivo em relevo quanto ao local em que se está no momento da fala. É o que vemos nos exemplos iniciais como em (6) e (57). Já no exemplo (61), esse espaço físico é ampliado, mas ainda mantém o mesmo relevo.

(6) F- Olha, brincava-se muito de roda e- aquele grupinho, não é? (Está) e <ti..>podia brincar aí FORA. à noite. 
E: Você prefere mais sé profissional liberal... as diferenças entre..,[ profissional liberal e funcionário público?]

(57) Ele: "Ah! Pode deixar minha filha!" ele ficava em cima do portão, para o lado de dentro. Porque, se ele ficasse do lado de FORA, o- era capaz do carro pegar ele ali. Uma vez, de manhã, eu estava saindo para ir na padaria, que eu tinha que ir com meus filho no médico, eu estava atrasada, estava saindo, quase que o caminhão me pega.( Peul-c-4)

(61) Assim- mas poxa! Queria conhecer tudo lá FORA, sabe? Um montão de lugares. Mas, (inint) um sonho muito alto. Mas que eu tinha vontade de conhecer FORA, tinha. não é? (Peul-c-5)

De modo impreciso, o falante não explica a que espaço físico se refere, podendo ser uma informação ancorada em qualquer espaço físico, exceto o local esperado para o desenvolvimento do evento citado. É o que vemos nos exemplos (58) e (50), reapresentados a seguir:

(58) "Só final de semana que eu faço alguma coisa pra gente comê ou a gente almoça FORA, tudo na rua, passa o tempo todo na rua."( Peul-r-1)

(50) 'Olha, eu não tenho base certa, porque eu nasci aqui, mas eu saí, vivi FORA aí por Madureira, Campo Grande e Botafogo. Até em Caxias, eu já morei. Aliás falar em outro Estado, Caxias já não é mais Rio de Janeiro, não é?” (Peul-c3)

Por extensão metafórica, tudo o que está no eixo externo deve ser considerado excluído do eixo interno, como nos exemplos (18), (23) e (61), em que essa orientação metafórica permite a reanálise como uma exceção.

(18) Sou uma mulher, sei lá! FORA de série, sabe? (Peul- c-12) 
(23) A função básica dos pronomes, afirma, é indicar a noção de pessoa. Explicita a noção de pessoa, sempre se remetendo ao evento comunicativo como uma estrutura, em que há um ou mais falantes (eu/nós), um ou mais ouvintes (tu/vós) e os seres que ficam FORA do eixo falante-ouvinte (ele/ela/eles/elas). (MODESTO, ATT- Dissertação p-17)

(61) “Assim- mas poxa! Queria conhecer tudo lá FORA, sabe? Um montão de lugares. Mas, (inint) um sonho muito alto. Mas que eu tinha vontade de conhecer FORA, tinha. não é?” (Peul-c-5)

Em relação ainda à abrangência espacial do advérbio $\boldsymbol{F O R A}$, pelo sentido da visão, tem-se que a palavra em foco pode representar:

(i) Visão - Local

Superior à visão:

(5) Ah, gostaria, sim, de viajar, ir à Europa, passear, não é? (est) Correr o- conhecer o mundo aí AFORA- isso no caso que o dinheiro desse. (Peul-c-11)

Inferior à visão:

(31) Eu acho que o brasileiro tá por FORA do que é Brasil, sinceramente, tanta coisa acontece e ninguém, quer dizê, todo mundo se dá conta, mas ninguém procura é... se interessá, sabe?" (Peul-r-4)

(ii) Movimento no espaço- verbos mais dinâmicos que são acrescidos em sua força de ação, pelo advérbio 'FORA'

Real:

(63) Ou então jogava alguma coisa nele, ele tacava FORA. (Peul-r-6) 
Imaginário:

(64) "Tem mulher, se passar FORA do horário [de]- de ir para casa, que não tem problema da mulher- não tem problema” (Peul-c-19)

\section{(iii) Proximidade no espaço}

Proximal: pela própria etimologia, não há a proximidade expressa com a palavra FORA.

Distal:

(65) "A senhora deixa eu com bambú tirar uma manga?" "Tudo bem, a gente deixa. Porque cai lá no chão, a gente joga FORA mesmo. Porque não acha ninguém para subir ali." (Peul-c-4)

\section{(iv) Lugar}

Interno:

(62) Sabe? Mas num vou FORA disso, eu não vou na igreja domingo à missa eu não vou . Eu fiz comunhão, casei na igreja, tudo, mas... ${ }^{32}$ (Peul-r-14)

Externo:

(66) fui passar roupa ali FORA, na área, peguei um ar, sabe?! (Peul-c-16).

\footnotetext{
${ }^{32}$ A noção de posição - /dentro/ no recontato 14 (PEUL) está mais ligada ao texto como um todo, podendo-se levantar a hipótese de haver união entre dois domínios, o da Semanticização e o da Discursivização. Talvez a negação sublinhada dê conta de inverter a posição espacial do item: "Sabe? Mas num vou FORA disso, eu não vou na igreja domingo à missa eu não vou . Eu fiz comunhão, casei na igreja, tudo, mas"... ${ }^{32}$
} 


\subsection{Discursivização}

Como processo de criação do texto e de sua ordenação em gêneros discursivos (CASTILHO, 2006), os advérbios atuam de modo peculiar, como explanamos a seguir.

O discurso se molda a partir de um locutor e de um interlocutor em um conjunto de atividades de negociação conversacional. A palavra FORA atua como desfocalizadora no seguinte conjunto de atividades:

\section{(i) organizar-se a interação através da elaboração do tópico conversacional}

(67) F: Tem que madrugá, durmo de um dia pro outro se fô preciso. Passá dois, três dias na fila, isso porque ? Porque é um colégio bom. E: Aí todo mundo quê, né? F: Aí todo mundo quê. FORA disso só pagano. (Peul-r-2)

(ii) reorganizar-se essa interação através dos procedimentos de correção $\underline{\text { sociopragmática abandonar-se o ritmo em curso através de digressões e parênteses, }}$ que passam a gerar outros tópicos discursivos.

(30) Não perca esta chance, cadastre-se agora mesmo em um dos nossos e-mails. Lembrando que todos eles tem a garantia de que ninguém (FORA você mesmo) estará lendo o seu e-mail. ou seja. você terá privacidade total. (http://orbita.starmidia.com/frasez/seuemail.htm)

(iii) estabelecer-se a coesão textual. 
A formação interrogativa apenas se refere à concordância que o locutor deseja ter do interlocutor e manutenção de turno conversacional

(68) A-Quais são os seus maiores desafios?

B- $\mathrm{Eu}$ acho que, hoje, meu principal desafio é o trabalho que venho desenvolvendo na IdeiasNet, que é a primeira empresa brasileira de Tecnologia da Informação a abrir seu capital na Bolsa de São Paulo. E meu objetivo é fazer a Internet superar os desafios que ela tem de enfrentar em termos de rentabilidade. O segundo desafio é transformar a IdeiasNet em uma empresa vitoriosa e estamos trabalhando nisso intensamente, viabilizando a captação de novos negócios e parcerias. FORA isso, há também o desafio de eu me manter sempre atualizado sobre o que anda acontecendo no mercado. ${ }^{33}$

\subsection{Gramaticalização}

Castilho (2006:29) afirma que o domínio da Gramaticalização é analisado a partir das alterações da estrutura fonológica (fonologização), da estrutura morfológica (morfologização) e da estrutura sintática (sintaticização).

\section{- Fonologização}

Um dos padrões funcionais de $\boldsymbol{F O R A}$ sofre irrefutável processo de alteração fônica ao receber uma vogal protética, a partir da aproximação da preposição "a" ao seu radical. Esse caso foi exemplificado em (5). Com relação aos demais padrões, não é insuspeito o desgaste fônico entre outras palavras vizinhas, entretanto, devido à fraca evidência eximimo-nos da explanação neste momento. Diacronicamente, essas alterações fônicas podem desencadear alterações mórficas.

33 Outro exemplo colhido no site http://www.timaster.com.br/revista/materias/main_materia.asp? codigo $=567 \&$ pag $=2$, em 07-07-07, por não constar um similar no corpus do PEUL . 
(5) F- Ah. gostaria, sim. de viajar, ir à Europa, passear, não é? (est) Correr o-conhecer o mundo aí AFORA- isso no caso que o dinheiro desse.

E- A terra dos seus pais?

E- A terra dos seus pais?

F- Também. Está aí. Também. (est)” (Peul-c-11)

\section{- Morfologização}

AFORA é um advérbio $\left(a^{1}+\boldsymbol{F O R A}\right)$, significando o mesmo que FORA. Como preposição, 'AFORA' tem o valor de 'à exceção de, além de, exceto'. Portanto, trazendo valor diferente daquele assumido pela mesma forma no exemplo (5), em que o sentido indica um movimento sem direção e velocidade, mas também sem ponto de chegada.

Percebemos que a união da preposição ao advérbio 'FORA' traz a construção verbal com significações diferentes, como em:

(31) "F: Eu acho que o brasileiro tá por FORA do que é Brasil, sinceramente, tanta coisa acontece e ninguém, quer dizê, todo mundo se dá conta, mas ninguém procura é... se interessá, sabe?” (Peul-r-4)

Nessa construção verbal o significado do item 'FORA' se desloca do âmbito do espaço físico para o espaço mental, significando 'desconhecer, ignorar, estar inferior a algo (informação, por exemplo) ou alguém (em relação a uma informação). O verbo que o antecede e faz parte da construção sofre um processo de esvaziamento lexical e dessemantização (o conteúdo semântico se torna tênue ou até nulo). O mesmo processo ocorre com os exemplos que se seguem: 
(70) "Eu acho que o SENAI tinha que fazer <es->- obras por FORA. (est)("espécie") de uma fábricas, não é? (est) Então, o aluno, depois [do]- do terceiro ano ("seguro"), já pegava uma obra para fazer. Aquela obra seria vendida. (est) ("alguma") Fábricas de automóveis, qualquer coisa-(está)" (Peul-c-8)

(33) “E: O almoço já está incluído na mensalidade ou é pago por FORA?” (Peul-r-8)

Fazer e pagar como verbos plenos se ressemantizam pela união com o item FORA, formando a expressão 'por FORA', que traz a idéia de ação não-inclusiva ou não-permitida. Na visão de 'não-inclusiva' ainda se pode apreender a noção etimológica inicial da palavra ' $\boldsymbol{F} \boldsymbol{O R} \boldsymbol{A}$ ', como no exemplo (70). Já, no exemplo (33), significa a não-permissão da ação ou a ação ilícita. Assim sendo, a palavra 'FORA' é o gatilho transformador da ressemanticização desses verbos.

\section{- Sintaticização}

A justaposição e a conformação sintática de outros itens muito próximos - e co-ocorrentes - denunciam a sintaticização dos itens sob análise. O efeito da sintaticização é, diacronicamente, a emergência de novos valores semânticos decorrentes dessa cristalização (freqüência na co-ocorrência) sintática.

É possível observar a sintaticização da palavra FORA por meio da anteposição do verbo "trabalhar", tal como vemos no exemplo. O mesmo se dá com relação aos verbos "passar" e "jogar", com o valor de "desenvolver ação sobre" ou atuar. O que era um satélite passa a ser reanalisado como uma seqüência verbal que desencadeia interpretação diferente daquela do item-fonte verbal (passar, jogar e trabalhar). Há, somente, um porém: não temos a convicção de que esse processo 
possa ser abarcado pela gramaticalização. Temos a impressão de que há um processo de lexicalização atuante. Não é a primeira vez, contudo, que essa dúvida se manifesta na checagem de princípios teóricos.

Ilustrando com os exemplos (52) e (39) a seguir, ambos identificam o ponto de partida para a análise neste domínio, pois há o espaço cronológico e o psicológico como o referencial para o mental.

(52) Em síntese, quer dizer: se você se casar você se casando, a sua mulher não vai trabalhar FORA? (Peul-c-2)

(39) F- Está. (riso) (ruídos)

E-("levando") O garoto direitinho, hein? E, me conta uma coisa. Quando você casar, você vai deixar (ruídos) a sua mulher trabalhar FORA ou não?

(Peul-c-1)

Os exemplos (52) e (39) são analisados em comparação com 'almoçar FORA' e 'comer FORA'. Há a posição do espaço como locativo em perspectiva dinâmica pelo próprio verbo ser semelfactível como nos exemplos (58) e (69) em que não se explicitou a regularidade da ação.

(58) Só final de semana que eu faço alguma coisa pra gente comê ou a gente almoça FORA, tudo na rua, passa o tempo todo na rua. (PEUL r1)

(69) Eu não como em restaurante ("lá embaixo") na cidade... normalmente eu gosto mais da minha comida feita aqui mesmo, por mim, do que comer FORA. (PEUL c3) 
Analisar dados em conjunto à luz de domínios diversos favorece uma compreensão mais ampla das mudanças lingüísticas implementadas na língua, em toda a sua dinamicidade.

Nesses pressupostos a língua ocorre como um processo mental, pré-verbal, mas é analisada a partir do corpus formado do mesmo nicho da abordagem clássica, ou seja, nos produtos "prontos e acabados", o que agrega uma nuança de incompatibilidade entre a teoria multissistêmica e a base para aplicação da mesma, pois não temos como conferir à formação pré-verbal uma análise em dados relacionados à língua-produto.

Pelos exemplos, até então analisados, a palavra em foco faz o caminho do mais lexical, como o adverbial até o de um uso prepositivo, evidenciando a unidirecionalidade do processo de gramaticalização. Além disso, pode-se inferir que o processo cognitivo desenvolvidos pelos estudos de Heine (1991a) dê conta desse processo mental por partir de uma ordem em relação à incidência de categorias cognitivas, nas quais podemos nos fiar, para explicarmos os princípios e mecanismos que geram a gramaticalização.

Obviamente, uma teoria não deve ser abandonada se nela houver alguns parâmetros que nos auxiliem para o entendimento da palavra em foco, fornecida pela comunicação ativa.

Dentro dos vários sistemas abordados pela Teoria Multissistêmica, há o da gramaticalização que nos auxiliou a entender o amálgama pelo qual a palavra fora passa, como exemplo ao ser agregada ao prefixo "a-" vem a formar uma nova palavra com função muito próxima da palavra inicial, podendo ter iniciado o processo pela fonologização, ampliando-o para a morfologização, como, por exemplo, ao ser unida a um verbo modifica-o pelo esvaziamento lexical e dessemantização. Ou na 
sintaticização, conformação sintática, em que o fora passa a ser analisado não como satélite, apresenta-nos a palavra como seqüência verbal (passar, jogar e trabalhar).

Muito próxima dessa análise está a baseada no modelo de Heine, Claudi \& Hünnemeyer (1991) na qual as categorias cognitivas derivam da concreta para a abstrata, do locativo espacial para o mental, por exemplo. Enfim, a mudança pode ser do plano de concreto para abstrato na mesma categoria ou em outras como advérbio > preposição, marcando a unidirecionalidade no processo de gramaticalização.

\section{Os padrões funcionais e as amostras estudadas}

A língua é admitida como instrumento de interação social, tendo como função a comunicação que ocorre em competência comunicativa do falante nativo que possui a habilidade de interagir socialmente. Portanto, o quadro em que ocorre a fala é o pragmático, e dentro desse quadro é que a semântica e a sintaxe são analisadas junto do contexto em que ocorrem.

Assim sendo, consideramos importante proceder à análise das amostras de três falantes do Peul ${ }^{34}$. Essas amostras ocorrem em contato de 1980 e recontato de 2000 das entrevistas com os falantes.

Esta seção se restringe a checar se a unidirecionalidade atua do processo de gramaticalização da palavra FORA. Faremos isso a partir das entrevistas de três informantes gravados em dois momentos diferentes, separados na linha do tempo por 20 anos.

\footnotetext{
${ }^{34}$ Cremos ser interessante a colocação dos exemplos colhidos a partir das gravações dos três falantes em contato e recontato do PEUL como anexo ao invés de mantê-los no corpo da dissertação.
} 
Iniciaremos com a amostra de contato apontando a recorrência nas tabelas indicando os dados relativos ao contato no século $\mathrm{XX}(\mathrm{C})$ e ao recontato no início do século XXI (R):

Tabela de contato/recontato - PEUL- três informantes

\begin{tabular}{|l|l|l|l|l|l|l|l|l|}
\hline \multirow{2}{*}{$\begin{array}{l}\text { Padrões } \\
\text { funcionais }\end{array}$} & \multicolumn{3}{|c|}{ Jan } & \multicolumn{2}{c|}{ Jup } & \multicolumn{2}{c|}{ Lei } & \multicolumn{2}{c|}{ Totais } \\
\cline { 2 - 10 } & C & R & C & R & C & R & C & R \\
\hline FORA1 & 2 & 2 & 1 & 1 & 2 & 1 & 5 & 4 \\
\hline FORA2 & 2 & 2 & 0 & 3 & 0 & 0 & 2 & 5 \\
\hline FORA3 & 1 & 0 & 0 & 0 & 0 & 0 & 1 & 0 \\
\hline FORA4 & 0 & 3 & 0 & 0 & 0 & 2 & 0 & 5 \\
\hline FORA5 & 0 & 0 & 0 & 0 & 0 & 0 & 0 & 0 \\
\hline FORA6 & 1 & 0 & 0 & 1 & 0 & 0 & 1 & 1 \\
\hline FORA7 & 0 & 0 & 0 & 0 & 0 & 0 & 0 & 0 \\
\hline FORA8 & 0 & 0 & 0 & 0 & 0 & 0 & 0 & 0 \\
\hline FORA9 & 0 & 2 & 0 & 0 & 0 & 0 & 0 & 2 \\
\hline FORA10 & 0 & 0 & 0 & 0 & 0 & 0 & 0 & 0 \\
\hline FORA11 & 8 & 6 & 10 & 2 & 1 & 1 & 19 & 9 \\
\hline Total & 14 & 15 & 11 & 7 & 3 & 4 & 28 & 26 \\
\hline
\end{tabular}

Diante da informação que os dados de língua falada carioca somaram um total de 54 tokens, podemos agora nos perguntar acerca da mudança lingüística em si. O que dizem os lingüistas acerca da mudança lingüista varia de quadro teórico para quadro teórico. Os formalistas crêem que a mudança seja implementada pela criança; os sociolingüistas crêem que a mudança se opere a partir dos adolescentes, que passam a rejeitar o modelo de seus pais. Funcionalistas preocupados com a gramática funcional questionam essas asserções, por julgarem que muitos são os eventos que podem desencadear mudanças lingüísticas na sociedade, mas todas obedecem a uma direção de abstratização cognitiva bastante lógica. 
Perguntamo-nos se adultos podem então mudar o quadro de usos em situações interativas registradas em momentos distintos. Os resultados que amparam nossas observações estão apresentados na tabela anterior.

Observamos que, em ordem de freqüência, o mais recorrente é o FORA11, em contato, mantendo-se altamente freqüente em situação de recontato também. , Em segundo lugar na ordem de recorrência, há o FORA1 mantendo sua freqüência de uso estável nos dois momentos de registro. Alguns padrões funcionais não podem ser alvo de comentário por manterem-se estáveis ou com diferença irrelevante de uso. É o que ocorre com os demais padrões, à exceção do FORA3 que revela um pequeno acréscimo de usos em dois falantes. Com relação ao padrão funcional 11 ocorreu de forma pouco estável, não configurando, contudo, um aumento de usos inovadores. Ao contrário, no século XX o uso foi mais acentuado do que no século XXI. Portanto, ratifica-se uma curva interessante de mudança lingüística em desenvolvimento que denota o papel do falante adulto na mudança lingüística.

Pode-se argumentar a respeito do baixo número de ocorrências para se afirmar uma mudança lingüística em curso. De fato, somente seria possível defender uma mudança na língua portuguesa por dois caminhos: 1. o desenvolvimento de um estudo pancrônico com amostragem controlada e significativa da comunidade; ou 2. por meio do estudo da trajetória social dos usuários da língua nos dois momentos.

Nesta dissertação, no entanto, nosso objetivo era verificar a direção da mudança e a validade de alguns postulados teóricos que refutam a unidirecionalidade e a derivação. Notamos, após incursões analíticas e a testes exaustivos, que o item fora tem empreendido uma mudança em direção à abstratização, ainda que em número de ocorrências de um século para outro não se possa identificar um correlato para a gramaticalização. 


\section{Considerações finais}

Nesta dissertação, apresentamos o percurso da pesquisa realizada sobre o comportamento funcional da palavra FORA, tendo como pano de fundo a fundamentação teórica funcionalista. Observamos, por meio de textos escritos e orais, 11 padrões funcionais identificados a partir de dados do corpus constituído.

No capítulo I, apresentamos os pressupostos teóricos funcionalistas que permitem a análise de um item em transição de lexical a gramatical. Com esse aparato teórico, pudemos analisar a passagem por mecanismos de mudança, tais como os de metáfora e de metonímia, ligados aos princípios da gramaticalização. Esse é um dos processos recorrentes nas línguas naturais em que um item se abstratiza, ou seja, deixa de ser lexical para se tornar gramatical ou de menos gramatical torna-se mais gramatical, sendo submetido a outras mudanças como recategorização e deslizamentos funcionais que confirmam a natureza da gramaticalização.

No capítulo II, tratamos dos aspectos metodológicos que envolveram a constiutição da amostra de língua falada e escrita. Apresentamos a distribuição das amostras em gêneros e apresentamos o quadro com informações diastráticas dos informantes cariocas. Discutimos a importância de incluir amostras escritas de natureza diversa, e optamos pelas dissertações de mestrado e pelas páginas da internet.

No capítulo III, organizamos as informações coligidas sobre o item-fonte adverbial fora e seus valores a partir de acepções registradas em obras lexicográficas. Também mobilizamos duas gramáticas e recolhemos ali informações sobre a categorização considerada adequada para a língua padrão. 
No capítulo IV, pudemos propor a checagem de modelos de análise vinculados à gramaticalização, concluída com observações acerca das proximidades entre esses modelos operacionais.

Deixamos claro logo de início que entendemos que a língua possa ser tomada como objeto de analítico "produto" em que se podem encontrar as pistas continentes da historicidade do falante nativo na comunicação. É nesse produto que nos embasamos para aplicar os princípios da gramaticalização, postulados por Lehmann (1982), Hopper (1991) e Heine, Claudi e Hünnemeyer (1991) em que o caminho para o item percorrer é o da abstratização até seu possível desaparecimento.

A despeito de a gramaticalização ser unidirecional, podemos afirmar que é uma verdade incontestável. Se a mudança caminha, entretanto, em direção diversa da representada pelo continuum concreto $>$ abstrato, então já não se pode afirmar que se trate de gramaticalização. Trata-se, sim, de casos de lexicalização. Aliás, mesmo as mudanças operadas num processo de lexicalização são unidirecionais ditadas pelo continuum abstrato $>$ concreto.

Evidenciamos na fundamentação teórica e, depois, na checagem de modelos, que há autores que desacreditam na unidirecionalidade. Mostramos que um desses autores é Castilho (2003), que nega lidar com a língua-produto. Defende que o multissistema funciona adequadamente para a língua-processo, no entanto, mobiliza dados realizados por falantes (língua-produto).

Não necessariamente Castilho pretende contrariar a teoria clássica da gramaticalização, pois, segundo suas palavras, não se admite derivação entre os processos. Assim, não haveria derivação entre léxico e gramática. Seriam domínios independentes em que a palavra poderia ser selecionada e posteriormente produzida. 
Essa seleção para produção se dá por princípios de ativação, desativação e reativação dos sistemas lingüísticos.

Então a direção seria multifacetada, pois não teria início em léxico ou palavras mais lexicais (substantivos) para se chegar às mais gramaticais (preposições), mas evidenciamos que essa derivação se dá de modo incontestável com os dados do item fora.

Ao estudar as proposições dos autores checados, surgiram várias indagações, que impulsionaram a pesquisa em relação à unidirecionalidade do processo de gramaticalização:

$1^{\mathrm{a}}$.- Inicialmente, tínhamos com hipótese que, nas línguas em geral, pelo que se conhece da história, os advérbios originariam as conjunções.

Explicamos que a recategorização da palavra FORA afetará, dependendo do tipo de processo envolvido (gramaticalização ou lexicalização) seu estatuto de palavra invariável. Se se convertesse a verbo, tornar-se-ia uma palavra flexiva, como todo verbo, ainda que continuasse fixo à direita do verbo, como um advérbio.

Se, no entanto, se tornar uma preposição, continuará não-flexiva e seguirá as tendências prepositivas de uso.

$2^{\mathrm{a}}$. As recategorizações sucessivas da palavra FORA recaem em classes mais gramaticais. A exemplo tem-se a palavra FORA como preposição codificadora de exclusão, tornando-se ainda mais decategorizada, pois se converte em expressão adverbial de cunho temporal e locativo (FORA3). Olhos incautos poderiam aceitar a mesma formação sintática como preposição temporal ou locativa e não perceber a diferença de uso do FORA3 e do FORA4, sendo que o último padrão funcional denota função prepositiva de exclusão da informação ao item subseqüente. 
Em um outro padrão funcional, temos o padrão funcional FORA5, considerado o uso mais inovador. FORA que surge como locução aparentemente conjuntiva e indica acréscimo de argumento. $\mathrm{O}$ seu uso sinaliza que o falante considera o argumento a ser acrescido portador de obviedade. Pode, também, indicar explicação ou conclusão.

3 . A modalidade falada é a instância das grandes inovações gramaticais, portanto, deverá ser também o locus da maior recorrência das recategorizações. Pode-se encontrar o ponto de união entre as modalidades de fala e de escrita, como afirma Marcuschi (2002), em blogs e orkuts, instâncias em que se usa a modalidade de escrita agregada às estratégias da modalidade da fala.

$4^{\mathrm{a}}$. A unidirecionalidade somente poderá ser apreensível por meio da verificação da abstratização das categorias cognitivas. Se admitirmos apenas os padrões funcionais, encontraremos a possibilidade do processo inverso ao da gramaticalização, configurando-se o processo de lexicalização. Assim é que do padrão em que temos um verbo seguido do advérbio FORA dê origem a um novo verbo intransitivo. Trata-se do verbo-suporte, que incorpora informações complementares ao seu sema, convertendo-o de complemento sintático a parte integrante do sentido a ser expresso de forma plena. Em suma, essa é a cristalização sintática em que o verbo assume o advérbio como parte dele mesmo, permitindo ao segundo modificar-lhe não apenas atribuindo-lhe a noção de lugar físico, mas também, o mental.

Essa cristalização sintática transforma as duas palavras em seu campo semântico, propulsionando o mecanismo de mudança ao uni-las, mesmo que elas advenham de domínios cognitivos diferentes que, para sua compreensão, usa-se de 
transferência conceptual e as reinterpreta como uma única expressão (metonímia), tornando-se cada vez mais complexa e completa.

Em suma, ficam aqui registrados os resultados auferidos durante os vários momentos de desenvolvimento da pesquisa, relatados nesta dissertação: 1. adultos têm influência importante no desenvolvimento e rumos de itens gramaticais nas línguas; 2. itens lexicais podem empreender trajetórias tão fortes que passam a gramaticais e depois a discursivos, como foi o caso da função de desfocalizador assumida; 3. a freqüencia type nem sempre é suficiente para calcular o grau de gramaticalização do item estudado; 4. não se pode propriamente negar a não-derivação entre os processos de mudança empreendidos por um item lexical na língua portuguesa, já que a polissemia revela que os variados padrões funcionais são historicamente relacionados; e 4 . a unidirecionalidade da mudança se impõe como fato: de itens mais concretos a itens mais abstratos. 


\section{BIBLIOGRAFIA}

\section{REFERÊNCIAS BIBLIOGRÁFICAS}

AUlETE, C. Dicionário Contemporâneo da Língua Portuguesa. 5.a. edição. Rio de Janiero: Editora Delta, 1970.

BECHARA, E. Moderna Gramática Portuguesa. Rio de Janeiro: Lucerna, 1999.

BLOCH \& VON WARTBURG.I. Dictionnaire Étymologique de la Langue Française. 1. ${ }^{a}$ édition: 1932 (8. édition, 1989). Paris; Presses Universitaires de France (1989).

BLUTEAU, R. Vocabulário Português et Latino, Áulico... autorizado com exemplos dos melhores escritores portugueses e latinos, e oferecido a El-Rei de Portugal, D.João V. Coimbra, Colégio das Artes da Companhia de Jesus; Lisboa: José Antônio da Silva, 1713. (volumes 1 e 6 )

BORBA, F. Dicionário Gramatical de Verbos do Português Contemporâneo do Brasil. São Paulo: Unesp, 1997.

BUENO, F. da Silveira. Dicionário Escolar da Língua Portuguêsa. 7.a. edição. Ministério da Educação e Cultura. FENAME, 1956.

BYBEE, J. Mechanisms of change in grammaticization: the role of frequency. In: Joseph, B. \& Janda, R.(eds). A handbook of historical linguistics. Blackweel, 2003.

BYBEE, J., PERKINGS, R., PAGLIUCA, W. The evolution of grammar: tense, aspect, and modality in the language of the world. Chicago: The University of Chicago Press, 1994.

CAMPBELL, L. \& JANDA, R. Introduction: conceptions of grammaticalization and their problems. In: Language Sciences 23, 2001, p.93-112.

CASTILHO, A. T. . "Proposta funcionalista de mudança lingüística" In: Jânia Ramos. (Org.). Para a História do Português Brasileiro. Belo Horizonte: Universidade Federal de Minas Gerais, 2003, v. Vol. 5, p. 45-70.

- Abordagem da língua como um sistema complexo: Contribuições para uma nova Lingüística Histórica, USP, CNPq, 2006. Inédito.

"A Gramaticalização". In: Estudos Lingüísticos e Literários. Universidade Federal da Bahia, 1997, p. 25-63.

CINTRA, Geraldo de Ulhoa \& CRETELA JR., José. Dicionário Latino-Português. São Paulo: Anchieta, 1944.

CUNHA, Antonio Geraldo de. Dicionário Etimológico Nova Fronteira da Língua Portuguesa. 2 ed. Rio de Janeiro: Nova Fronteira, 1982. 
CUNHA, C.; CINTRA, L. Nova gramática do Português Contemporâneo. 3. ed. Rio de Janeiro: Nova Fronteira, 1985.

DEFENDI, Cristina Lopomo. A reduplicação no português culto falado em São Paulo. Dissertação de Mestrado. Programa de Filologia e Língua Portuguesa. São Paulo: Universidade de São Paulo, 2008.

DEVOTO, G. \& OLI, G.C. Nuovo vocabolario illustrato della língua italiana. Prima ristampa (1987). Firenze: Casa Editrice Felice Lê Monnier S.p.A., 1988.

DUBOIS, Jean et alii. Dicionário de Lingüística. São Paulo: Cultrix, 1986.

ERNOUT, A. e MEILLET, A. Dictionnaire Étymologique de la Langue Latine Histoire des Mots. Troisième Édition Paris: Librairie C. Klincksieck, 1951

FERREIRA, Aurélio Buarque de Holanda, Novo Aurélio Século XXI: O dicionário da Língua Portuguesa, $3^{\text {a }}$ edição, Rio de Janeiro, Nova Fronteira, 1999

FERREIRA, Beatriz Grossi. Gramaticalização dos itens AINDA e SEMPRE no Português culto de São Paulo. II Encontro do Grupo de Pesquisa CNPq/USP "Mudança Gramatical do Português - Gramaticalização” Relatório de Estágio, 2007.

FONSECA, José da. Diccionario da Língua Portugueza e Diccionario de Synonymos seguidos dos diccionario Poetica e de Epithetes. Feito inteiramente de novo e consideravelmente argumentado por J. I. Roquete. Paris- Lisboa: Livraria Aillaud e Bertrand, 1848.

FREIRE, Laudelino, Grande e Novíssimo Dicionário da Língua Portuguesa, Volume III, $2^{a}$ edição. Rio de Janeiro: José Olympio Editora, 1954.

GONÇALVES, Sebastião Carlos Leite. Gramaticalização, modalidade epistêmica e evidencialidade: um estudo de caso no português do Brasil. Tese de doutoramento, 2003.

GONÇALVES, Sebastião Carlos Leite; LIMA-HERNANDES, Maria Célia \& CASSEB-GALVÃO Vânia Cristina. Introdução à gramaticalização: princípios teóricos e aplicação. São Paulo: Parábola Editorial, 2007.

HEINE, Bernrd; CLAUDI, Ulrich; HÜNNENMEYER, Friederike. Grammaticalization - A Conceptual Framework. Chicago/London: University of Chicago, 1991a.

From cognition to Grammar: Evidences form African languages. In TRAUGOTT. Elisabeth.C.; B(orgs) Approaches to Grammaticalization. Amsterdam: John Benjamin, 1991b.

HEINE, Bernd ; REH, M. Grammaticalization and reanalysis in African languages. Hamburg: Helmut Buske, 1984.

HEINE, Bernd. Grammaticalization. In: JOSEPH, Brian D. e JANA, Richard D. The handbook of historical linguistic. Oxford: Blackwell, 2003. 
HOPPER, Paul. J.\& TRAUGOTT, Elizabeth Closs. "The History of Grammatizalization". In: Grammaticalization. Cambridge: Cambridge University Press, 1993.

HOPPER, Paul. J. “On some principles of grammaticization". In: Approaches to Grammaticalization. Vol. I. Amsterdam/Philadelphia: John Benjamins Publishing Co., 1991, p.17-35.

HOPPER, Paul J. \& Sandra A. Thompson. 1984. The discourse basis for lexical categories in universal grammar. In: Language 60.4:703-752.

HOUAISS, Antonio \& VILLAR, Mauro de Salles. Dicionário Houaiss da Língua Portuguesa. Rio de Janeiro: Objetiva, 2001.

LEHMANN, Christian. Thoughts on grammaticalization a pragmatic sketch, akup, n.48. v.1. 1982.

LIMA, Bernardo de \& Bacellar, Melo. Diccionario de Língua Portugueza - Em que se acharão dobradas palavras do que traz Bluteau, e todos os mais Diccionaristas juntos. Lisboa: s/e, 1753.

LIMA-HERNANDES, Maria Célia. Interface Sociolingüística/Gramaticalização: estratificação de Usos de Tipos, Feito, Igual e Como - Sincronia e Diacronia. Tese de doutoramento. Campinas: Instituto de Estudos da Linguagem/ Universidade Estadual de Campinas, 2005.

MACHADO, José Pedro. Dicionário Etimológico da Língua Portuguesa. 2 ed. Lisboa: Confluência, 1967.

MARCUSCHI, L.A. Da fala para a escrita. São Paulo: Editora Cortez, 2007.

MONTEIRO, J. L. Para compreender Labov. Petrópolis. Rio de Janeiro: Vozes, 2000.

NASCENTES, Antenor, Dicionário Etimológica Resumido, Instituto Nacional do Livro, MEC, 1966.

NEVES, Maria Helena de Moura. A gramática funcional. São Paulo: Martins Fontes, 1997.

NEVES, Maria Helena de Moura. Gramática de usos do português. São Paulo: Unesp, 2000 .

NEVES, Maria Helena de Moura. Texto e gramática. São Paulo: Contexto, 2006.

POGGIO, R.M.G.F. Processos de gramaticalização de preposições do latim ao português. Salvador:EDUFBA, 2002. 
QUICHERAT, L. Novíssimo diccionario latino-portuguez.(etymologico, prosódico, histórico, geographico, mythologico, biographico, etc).Rio de Janeiro:B.L. Garnier (livreiro-editor), s/d.

SILVA, Andressa Carvalho da. Dissertação de Mestrado. O Desenvolvimento IntraInterlingüístico Intandem- A Distância (Português e Espanhol). Instituto de Biociência, Letras e Ciências Exatas da Universidade Estadual Paulista, Programa de PósGraduação em Estudos Lingüísticos na Área de Concentração: Lingüística Aplicada. São José do Rio Preto, 2008.

SILVA, Antonio de Moraes. Diccionário da Língua Portugueza.6.a. edição (melhorada, e muito accrescentada pela desembargador Agostinho de Mendonça Falcão (sócio da academia Real da sicencias de Lisboa) Tomo II - F-Z. Lisboa: Typographia de Antonio José da Rocha, 1858.

SPAZIANI, Lídia. (2007) Gramaticalização do item "fora" - atuação das categorias cognitivas. Apresentação no II EPOG - 2007.

(2007) fora - Uma breve visão da dimensão semântica no deslizamento funcional como uma das possíveis rotas de gramaticalização. In: Estudos Lingüísticos do GEL- XXXVI(2), maio-agosto, 2007. p. 221 / 229

(2007) fora que e além do que: variação lingüística no português brasileiro. Apresentação no II Seminário Internacional de Lingüística da Unicsul e II SIL Unicsul, 2007.

(2007) Fatores de gramaticalização do advérbio 'fora' nos princípios sociocognitivos. Comunicação Coordenada- Análise Multissistêmica de Advérbios ABRALIN- 2007.

SVOROU, Soteria. The Grammar of Space. John Benjamins Publishing Company. Philadelphia, 1993.

SWEETSER, E. From etymology to pragmatics- metaphorical and cultural aspects of semantic structure. Cambridge, CUP:1997.

TRAUGOTT, Elizabeth C.; KÖNIG, Ekkehard. "The semantics-pragmatics of grammaticalization revisited". In: Approaches to Grammaticalization. Vol. I. Amsterdam/Philadelphia: John Benjamins Publishing Co., 1991, p.17-35.

On the rise of epistemic meanings in English: an example of subjectification in semantic change. In: Language Journal of the Linguistic Society of America. Baltimore:Waverly Press Inc. March 1989, p.31-55.

From propositional to textual and expressive meanings: some semantic- Pragmatic Aspects of Grammaticalization. In. Perspectives on historical linguistics.Amsterdam/Philadelphia: John Benjamins Publishing Company, 1982, p.245-271. 
VIARO. Mário E. Das preposições latinas às do português e do romeno: derivações semânticas. São Paulo, dissertação de mestrado, 1994.

VIARO, Mário E. Estruturas cristalizadas de verbo + advérbio de lugar no português. Fortaleza: UFC, 2003.

VOIGTLANDER, Katherine; BARTHOLOMEW, Doris. Semology and Transitivity in Eastern Otomi Verbs. IN: Lingua 29. Amsterdam:North Holand Publishing Company, 1972, 38-53.

\section{REFERÊNCIAS BIBLIOGRÁFICAS VIRTUAIS}

HOUAISS. Dicionário da língua portuguesa. Documento eletrônico. Disponível na Internet via WWW.URL : $<$ http://houaiss.uol.com.br/busca.jhtm?verbete= ass $\%$ E9dio\&stype $=\mathrm{k}>$. Acesso em 15 de maio de 2007.

MICHAELIS. Dicionário da língua portuguesa. Documento eletrônico.. Disponível na Internet via WWW.URL: http://www2.uol.com.br/michaelis/ Acesso em 15 de maio de 2007. 


\section{Anexo 1}

\section{Exemplos colhidos para análise do Fora a partir do corpus Peul (RJ), dissertações, sites diversos, blogs e orkuts.}

(1) F: [Acho que aqui FORA é melhor prá se trabalha] do que funcionário público, funcionário público tem que manda. Veja bem meu caso na área de educação (Peul- r-9)

(2) E: Ah, é ? Ah... sim. É... você já morou em outros lugares ? (Est) FORA o Aterro onde você nasceu...

F: Irajá e Anchieta. (Peul-r-adri)

(3) Em São Paulo, a maior cidade brasileira, o Grito dos Excluídos teve lugar diante do histórico Monumento da Independência, no bairro do Ipiranga. onde os manifestantes exclamaram os seguintes slogans: "Pátria livre é Pátria sem dívida" "FORA já, FORA já daqui o FHC e o FMI" e vaiaram os candidatos Maluf, Collor, Alckmin e Tuma. A candidata favorita nas pesquisas à prefeitura de São Paulo, a petista Marta Suplicy recebeu muitos aplausos da multidão. (http://www.verinha.de/grito_dos_excluidos.htm $<$ acesso 2008/05/05>)

(4) "Eu deveria ter nascido aí. Pois tirando a minha aparência (risos), gosto das mesmas coisas que vocês. Dançamos a mesma música, bebemos as mesmas bebidas, rimos das mesmas piadas. Esta será a minha única turnê no ano", diz o simpático inglês. "Decidi tocar porque amo o Brasil e os brasileiros. Eles parecem gostar de mim, também. FORA QUE o tempo na Inglaterra nesse período do ano é horrível", justifica, gargalhando".

(http://txt.jt.com.br/editorias/2007/01/26/var-1.94.12.20070126.1.1.xml)

(5) F- Ah. gostaria, sim. de viajar, ir à Europa, passear, não é? (est) Correr oconhecer o mundo aí AFORA- isso no caso que o dinheiro desse.

E- A terra dos seus pais?

E- A terra dos seus pais?

F- Também. Está aí. Também. (est)" (Peul-c-11)

(6) F- Olha, brincava-se muito de roda e - aquele grupinho, não é? (Está) e $<$ ti..>-podia brincar aí FORA à noite. (Peul-c-10)

E: Você prefere mais sé profissional liberal... as diferenças entre..,[profissional liberal e funcionário público?]

(7) Há tempo venho falando que o SPFC neste ano (FORA um ou dois jogos) não vem correspondendo com um bom futebol. Isso até certo ponto é normal pois perdemos peças fundamentais de conquistas recentes, como Danilo, Mineiro e Fabão. (http://www.saopaulofc.com.br/articles.php?id=576) 
(8) F: Olha, cê sabe que num dá prá mim vê direito porque eu fico (hes) eu pego oito horas, entro lá pró meu setor. [só saio quase] só saio duas hora prá bate o ponto, aí volto pró meu setor. fíco lá dentro, leio jornal, conversando, aí volto três hora. bato o meu ponto na entrada do almoço. E«tro e só saio na hora de i embora. Quase num vejo segundo grau, sabe?, lá FORA, quase num vejo. (Peul - r-8)

(9) Eu saía por esse canal, ("eu") ia pescar lá em cima com um colega, no domingo, ou lá para FORA- (est) mas a pescaria é uma coisa muito incerta, não é? (Peul- c-3)

(10) Bélgica. Bruxelas. França. Paris. E no outro dia. [ meus ]...[ meus ],..meu neto ficaram: mais vovô... E as sobrinhas lá de FORA também. [ que ]...que eu tinha o ginasial e eu digo: não, eu tenho o quarto ano primário, porque naquele tempo você estudava mesmo, sabe como é? (Peul- r-15)

(11) F: (Inint) parece um carnaval FORA de época (inint). (Peul- r-16)

(12) Esse embrião, uma vez FORA do ventre materno que o gerou (,..)(MASSI, MLG-Dissertação- p.111)

(13) Você sai, assim, muito daqui, você se diverte FORA do bairro [ou]- (hes) ou mais aqui dentro mesmo? [você tem-] (Peul- c-15)

(14) As motivações externas baseiam-se na relação entre a coisa significada e a forma significante FORA do sistema lingüístico. (ANJOS, E D - Dissertação p-190)

(15) O termo giro, FORA do contexto capoeirístico (...) (ANJOS, E D Dissertação- p-197)

(16) (...) prevendo a sua soberania ameaçada por um possível poder FORA do seu controle, por precaução, limita essa potência arrebatando-lhe a filha. (MASSI, MLG-Dissertação P-112-)

(17) Mas, os pais ocupantes de altos postos, embora honrados e cobertos de glória FORA de casa (...)(MASSI. MLG-Dissertação-p.88)

(18) Sou uma mulher, sei lá! FORA de série, sabe? (Peul- c-12) 
(19) F - [ah!] não, muitas não estarão, não é? Muitos já estão já- não é? FORA de forma, não é? (Peul- c-16)

(20) (...) o discurso lobatiano FORA dos padrões (Goh. Simone Strelciunas Dissertação- p.13)

(21) (...) sua definição etimológica- mesmo que imprecisa, FORA de um contexto e que servirá de origem (...) (Goh. Simone Strelciunas - Dissertação p-71 -)

(22) Há umas coisas FORA de foco. (Goh, Sirnone Strelciunas - Dissertação-p. 178)

(23) A função básica dos pronomes, afirma, é indicar a noção de pessoa. Explicita a noção de pessoa, sempre se remetendo ao evento comunicativo como uma estrutura, em que há um ou mais falantes (eiu nós), um ou mais ouvintes (tu/vós) e os seres que ficam FORA do eixo falante-ouvinte (ele/ela/eles/elas). (MODESTO, A T T - Dissertação p-17)

(24) ...decorrente das migrações constantes FORA do limite do grupo. (GOH. Simone Strelciunas - Dissertação p-55-)

(25) F: Tem que madrugar, durmo de um dia pro outro se for preciso. Passa dois, três dias na fila isso por quê ? Porque é um colégio bom.

E: Aí todo mundo quer, né?

F: Aí todo mundo quer... FORA disso só pagano (Peu3- r-2)

(26) Faltaram no texto paraguaios falsos, colombianos cheiradores e chilenos magérrimos de $2,20 \mathrm{~m}$. Isso não surpreende ninguém que leia este blog e percebe o quanto eu ignoro a América Latina, estando exilado em meu próprio cérebro desde 1994. Mas não ter encaixado holandeses maconheiros, finlandeses incompreensíveis e atrizes pornôs tchecas é algo por qual devo ser severamente criticado. FORA isso, comprem guarda-chuvas de aço, porque o Solon agora tem blog. É, é, não é só dele, é só sobre esportes. Tudo bem. Daqui a seis meses ele já está trabalhando com a teoria que a política é o spectator sport para os gordos assim como é o show biz dos feios. (http://ciscocosta.com/fílisteu/?cat=34)

(27) Moderador apresenta a mensagem enviada por naninha: Qual foi seu pior momento na casa?

Rogério responde para naninha: Não tive um pior momento, não tive um conflito. Acho que este horário meio doido, dormir tarde, almoçar tarde, deu 
uma alterada. Mas FORA isso, não tive nada de ruim (http://videochat.globo.com/GVC/ arqinvo/O..GO6244-3362.00.html)

(28) Falando em brasileiro, nunca vi tantos juntos em um soh lugar como aqui na Berlitz, Soh na minha sala tem 04 alem de mim. na minha homestav 01 e FORA o restante das escola, parecem que foram selecionados a dedos. Bom. se não en corenano. en brasileiro, rss, (http://FORAdecasa.blogger.com.br/ )

(29) Sabe? se falo: olha. quero fica sozinho, ela tem que respeita, agora existe, FORA nós dois, cada um ser uma pessoa, nós, por nós casarmos, existe um outro terceiro ser. que e justamente o nosso casamento. (Peul- r-6)

(30) Não perca esta chance, cadastre-se agora mesmo em um dos nossos e-mails. Lembrando que todos eles tem a garantia de que ninguém (FORA você mesmo) estará lendo o seu e-mail. ou seja. você terá privacidade total. (http://orbita.starmidia.com/frasez/seuemail.htm)

(30a) ...todos eles têm a garantia de que ninguém (exceto você mesmo) estará lendo o seu email....

(31) "F: Eu acho que o brasileiro tá por FORA do que é Brasil, sinceramente, tanta coisa acontece e ninguém, quer dizê, todo mundo se dá conta, mas ninguém procura é... se interessá, sabe?" (Peul-r-4)

(32) Brinco muito com ele com a questão de quebra-cabeças e brinquedos lógicos, evito de brincar com ele com arma de fogo, com esses robô de arma de fogo, eu deixo de FORA, apesar que já vi que é meio difícil (inint). (Peul- r-7)

(33) E: O almoço já está incluído na mensalidade ou é pago por FORA?(Peul- r-8)

(34) Por que que ele tem que ganhar por FORA pra poder trabalhar?(Peul- r-9)

(35) Mas, quando você está somente ficando, nada melhor que um bom FORA (tem que ser bem dado, claro) para acabar de vez com aquele namoro (ou ficada) que já não está legal. (http://www.terra.com.br/jovem/falaserio/2002/06/20/000.htm)

(36) a gente comemora sempre, não é? (risos) (rindo) Meu marido gosta de uma cervejinha... (est) (f) uns salgadinhos, então, é assim que a (est) gente comemora, não é? E os fogos por aí a FORA. (Peul- c-10) 
(37) O caminhoneiro Juliano Zardo diz que, no trecho paulista, a pista está com problemas. "É muito buraco, DE FORA A FORA da estrada." (http:// g1.globo.com/Noticias/Brasil/0,,MUL303357-5598,00empresa+proibe+funcionários + de + viajar + pela + regis + bittencourt.html)

(38) Desde que Débora soube que vai se apresentar na TV, a nojentinha tá se achando a estrela. É tanta piração que ela quer até evitar o contato com qualquer pessoa que seja um risco para sua carreira. Por isso, dá logo UM PASSA FORA em Pedro. (malhacao.globo.com/Novela/Malhação /0,AA1676829-4033,00)

(39) F- Está. (riso) (ruídos)

E-("levando") O garoto direitinho, hein? E, me conta uma coisa. Quando você casar, você vai deixar (ruídos) a sua mulher trabalhar FORA ou não? (Peul-c-1)

(40) Subimos no Santo Cristo, a primeira vez ele pulou a janela, saiu FORA. A segunda vez que a gente foi lá, aí eu subi por trás do morro, o tenente veio pela frente do prédio dele, quando ele viu o tenente, ele pulou a janela. (Peul-c-15)

(41) Eu fiquei assim ... achei estranho, né? num esperava assim o grau de violência que lá tem, entendeu? eh ... porque ó, eu fui no carnabelô que ... é carnaval FORA da época, né? (Peul-r-3)

(42) E- Você conhecer [tudo]- tudo que (inint)ganhar muito! [(inint)]

F- [pois é! Tinha] que ganhar sozinha, não é? Sozinha. (rindo)

E- Tem algum país assim que te interessa mais?

F- Ah! Tem vários! sabe? Tem vários países. (hes) Tinha loucura para conhecer. Para só ir assim passear sabe? (est)

F-Conhecer. Como é que é, como é que eles vivem lá FORA. Sabe? A maneira deles se portarem, sabe? Tudo isso! (Peul-c-5)_

(43) F: Corre. Até hoje ele (inint) "ah, vocês erraram no molequinho também erraram. Aonde me vê, oh (estala os dedos) "sarta" FORA. Aí ficou aquele negócio de resistro do neném, resistra, não resistra, resistra não resistra, eu falei: "Suele, você qué que eu resistro?" Que eu ía resistra o menino. Ela: "Ah, mãe resistra." Aí depois eu pensei bem, falei: “ah, não. Vou tirá a responsabilidade das costa dela, falei: "não. Não, vai você e resistra." Aí mandei ela chamá o pai dela, fiquei com o neném ela foi lá no cartório e resistrou o neném. 
(44) eu realmente fiquei decepcionada, eu pensei que fosse uma coisa assim mais tranqüila, mas FORA isso a cidade é muito linda, o povo é muito simpático, muito receptivo, acho que até mais do que o carioca porque o carioca é meio desconfiado. (Peul- r-3)

(44a) ... mas exceto isso a cidade é muito linda, o povo é muito simpático...

(45) Tais fenômenos, FORA de sua obviedade, ocultavam um poder divino (...)(MASSI, MLG-Tese) (2001:9)

(45a) Tais fenômenos, além de sua obviedade, ocultavam um poder divino...

(46) FORA preposicional $\rightarrow$ além: (...) aquelas que um deus usufrui FORA do domínio sagrado. (MASSI, MLG-Tese) (2001:p120-rodapé)

(47) Mas aquele que, persuadido pelos pássaros de tais palavras quiser, estando FORA da razão, explorar nossa profecia(...)(MASSI, MLG-Tese)

(48) São oito hora de serviço. Agora, (hes) nesse tempo das oito até meio-dia, aí, eu saio e vejo as coisa lá FORA- porque é bom o cara sair, tem [que]que esfriar a cabeça, aí, eu saio, eu vou para o cinema, [quando]- quando estou [com]- com dinheiro, não é? (Peul-c-19)

(49) F- [Ah!] Meu irmão, certo? Meu irmão é muito bacana, um padre maravilhoso, certo? Se ordenou tem cinco anos, Jaragu, primeira missa dele foi em Magalhães Bastos, é o primeiro padre aqui de Magalhães Bastos, celebrou a primeira missa aqui em Magalhães mesmo. Na primeira missa dele, eu tive a honra- ele fez a primeira comunhão da minha filha, certo? Pois é. FORA de serie. muito bacana. (f) E o meu irmão, ultimamente, ele agora é cantor também. além de ser padre é cantor. É. Tem disco gravado. (est) é. Que ficou quatro ano em ("garfanha") de Nazaré como vigário. Agora está em Jaragu. ("Um") padre excelente todo mundo gosta do meu irmão. Muito bacana, mas bacana mesmo. Não é conversa não. Meu irmão é FORA de série.(Peul-c7)

(50) Olha, eu não tenho base certa, porque eu nasci aqui, mas eu saí, vivi FORA aí por Madureira, Campo Grande e Botafogo. Até em Caxias, eu já morei. Aliás falar em outro Estado, Caxias já não é mais Rio de Janeiro, não é? (Peul-c-3) 
(51) Exatamente, então fica difícil saí, í ao cinema, pra saí lá FORA pra í a uma pizzaria, pagá estacionamento, gasolina, então isso tudo gasta, então entre gastá e economizá um pouquinho e terminá a minha obra, eu prefiro economizá, nem que fique em casa final de semana, ali no... no outro terracinho, tirano, veno a noite, o luar, muito bom (risos e) que eu... (Peul-r-12)

(52) ( ) Em síntese, quer dizer: se você se casar você se casando, a sua mulher não vai trabalhar FORA? (Peul-c-2)

(53) É mais não fui. Eu dei aula aqui em casa só sabe? Depois que... casada tudo... meu filho novo ainda tava até na faculdade. Eu dei aula, primeiro eu cosi muito pra FORA, fui costureira. (Peul-r-13)

(54) eu sei que o bolo é às cinco, eu (ruído) saí FORA, não fiquei! (Peul-r-10)

(55) E: [ est 56] Aí você paga por FORA?

F: Pago por FORA todo mês eu pago cento e quinze, manda depositá aí eu levo no banco e pago. (Peul-r-9)

(56) E: Que lugar do Brasil você gostaria de conhecer?

F: A Bahia.

E: E FORA do Brasil?

F: Nenhum. Lugar frio, guerra, não. Prefiro ficar por aqui mesmo (Peul-r-

8)

(57) Ele: "Ah! Pode deixar minha filha!" ele ficava em cima do portão, para o lado de dentro. Porque, se ele ficasse do lado de FORA, o- era capaz do carro pegar ele ali. Uma vez, de manhã, eu estava saindo para ir na padaria, que eu tinha que ir com meus filho no médico, eu estava atrasada, estava saindo, quase que o caminhão me pega.( Peul-c-4)

(58) almoça FORA- Só final de semana que eu faço alguma coisa pra gente comê ou a gente almoça FORA, tudo na rua, passa o tempo todo na rua.( Peul-r-1)

(59) E- Muita fralda para lavar, não é?

F- Ah, meu Deus do Céu! Antigamente não tinha essas fraldas descartáveis, essas fraldas que bota, joga FORA. Eu vejo a minha sobrinha lá, com o filho dela. sujou, <chi>, lixo.

E- Bem mais prático.

F- Muito mais, não é. (riso f) (Peul-c-11) 
(60) [Não, não,] para mim não teria problema, se ela conseguisse um emprego, que o emprego desse para pagar uma boa empregada, cuidar bem do meus filho, manter tudo conforme ela vem mantendo, tudo bem, agora, para conseguir um emprego, para ganhar um salário mínimo, eu pagar um salário mínimo à empregada para minha mulher ficar batendo perna na rua, (barulho de moto) não é interessante, certo? só para dizer que está empregada, para dizer que está trabalhando FORA, em vez de estar ajudando o marido, está prejudicando, não é interessante. e hoje em dia emprego de cem mil cruzeiro não está fácil de arranjar, certo? (Peul- c-7)

(61) "Assim- mas poxa! Queria conhecer tudo lá FORA, sabe? Um montão de lugares. Mas, (inint) um sonho muito alto. Mas que eu tinha vontade de conhecer FORA, tinha. não é?"' (Peul-c-5)

(62) Sabe? Mas num vou FORA disso, eu não vou na igreja domingo à missa eu não vou. Eu fiz comunhão, casei na igreja, tudo, mas... (PEUL r14)

(63) Ou então jogava alguma coisa nele, ele tacava FORA. (Peul-r-6)

(64) "Tem mulher, se passar FORA do horário [de]- de ir para casa, que não tem problema da mulher- não tem problema" (Peul-c-19)

(65) "A senhora deixa eu com bambú tirar uma manga?" "Tudo bem, a gente deixa. Porque cai lá no chão, a gente joga FORA mesmo. Porque não acha ninguém para subir ali." (Peul-c-4)

(66) fui passar roupa ali FORA, na área, peguei um ar, sabe?! (Peul-c-16).

(67) F: Tem que madrugá, durmo de um dia pro outro se fô preciso. Passá dois, três dias na fila, isso porque? Porque é um colégio bom. E: Aí todo mundo quê, né ?

F: Aí todo mundo quê. FORA disso só pagano. (Peul-r-2)

(68) A-Quais são os seus maiores desafios?

B- Eu acho que, hoje, meu principal desafio é o trabalho que venho desenvolvendo na IdeiasNet, que é a primeira empresa brasileira de Tecnologia da Informação a abrir seu capital na Bolsa de São Paulo. E meu objetivo é fazer a Internet superar os desafios que ela tem de enfrentar em termos de rentabilidade. O segundo desafio é transformar a IdeiasNet em uma empresa vitoriosa e estamos trabalhando nisso intensamente, viabilizando a captação de novos negócios e parcerias. FORA isso, há 
também o desafio de eu me manter sempre atualizado sobre o que anda acontecendo no mercado.

(69) Eu não como em restaurante ("lá embaixo") na cidade... normalmente eu gosto mais da minha comida feita aqui mesmo, por mim, do que comer FORA. (PEUL c3)

(70) "Eu acho que o SENAI tinha que fazer <es->- obras por FORA. (est)("espécie") de uma fábricas, não é? (est) Então, o aluno, depois [do]do terceiro ano ("seguro"), já pegava uma obra para fazer. Aquela obra seria vendida. (est) ("alguma") Fábricas de automóveis, qualquer coisa(está)" (Peul-c-8) 


\section{Anexo 2}

\section{Exemplos retirados dos informantes com contato e recontato no PEUL.}

\section{Informante Jan - Contato- 14 ocorrências}

FORA11- F- Olha, eu não tenho base certa, porque eu nasci aqui, mas eu saí, vivi FORA aí por Madureira, Campo Grande e Botafogo. Até em Caxias, eu já morei. Aliás falar em outro Estado, Caxias já não é mais Rio de Janeiro, não é?

FORA2 -F- Não!- Eu tinha aí, agora ate vendi o barco, que houve necessidade de vender. eu tinha um barquinho a motor. Eu saía por esse canal, ("eu") ia pescar lá em cima, com um colega, no domingo, ou lá para FORA- (est) mas a pescaria é uma coisa muito incerta, não é? Se tem peixe, mata o peixe, vende, tudo bem. mas às vezes a gente sai para o mar, ("fica") um dia, dois dia, três dias é na traz.

FORA2-F-(...). o peixe às vezes aqui na Barra, por exemplo, o peixe de uma semana, (f) de dois, três, quatro dias é considerado um peixe fresco e- com e- em relação ao peixe que se compra lá FORA. (est) ele apenas esta no congelador, porque ("você") não pode chegar é querer um peixe tirado na hora!

FORA1-F- Porque se eu tirasse conclusões se eu sair do Brasil é viajar por certos país aí FORA, aí é que eu vou dizer. (est) O Brasil não é tão bom assim como se diz, não. De isso aí! mas enquanto eu não conheço aí FORA, (est) (hes) eu não sei agora, político eu não queria ser nunca! Agora mesmo eles estão para botar ali [uma]- [uma]- uma cobertura, um abrigo para passageiro, de "ônibus. É o "ônibus? tem que botar o abrigo, mas botar o "ônibus. (riso de é) ontem eu fui a Campo Grande-...

FORA11- F- (...) Eu acredito que seja. não sei, eu vejo falar isso, mas não sei se é verdade. Eu não como em restaurante ("lá embaixo") na cidade. normalmente eu gosto mais da minha comida feita, aqui mesmo, por mim, do que comer FORA.

FORA11- F- Não sou bom preparador de peixe. Eu faço às vez, eu olho assim uma revista, uma coisa é faço por ali. Se sair bom, eu como; se sair ruim, eu tem ("que") comer mesmo para não estragar, (riso entrei.) para não jogar FORA, não é? (risos) a gente se defende como pode. Passar fome é que não deve, não é? (est)

FORA11- F- (...) . Tanto que às vezes eu pego um pedaço de pão aí, de ontem, que sobrou é (inint) para ("não") jogar FORA, porque eu fico com pena. ("aí") Eu- eu [não]não incomodo de comer, ou de ver uma pessoa comer, ou dar um pedaço de pão a uma pessoa que precise é tudo. Mas às vezes eu, (gesto) ah, com preguiça de ir lá comprar o pão, -sobrou meia bisnaga de ontem, eu pego aquele pão é torro na frigideira, ("ou") boto ele para esquentar, ele fica- mas há pessoas que fazem aquilo ate no g s. Pega uma metade do pão (est) é acende o fogão de g s, com um garfo, fica ali esquentando o pão. Eu acho que isso influi na saúde. 
FORA11- F- [Põe limão], sim. (...) Comia ostra (est) toda semana. Mas a ostra ("para mim") tinha que ser assim: saudável. Ostra viva. Se (est) estivesse morta, [inclusive tem ate mau cheiro, jogava FORA.] Se ("tivesse")- se ["ela") abrir, ela não presta; pode jogar (est) FORA. Se ela tiver fechadinha, ela está perfeita.

FORA11- F- Ah, acordo cedo, não tem hora bem de acordar. O mais tarde que eu acordo é seis horas. (est) De acordo com o cansaço. Às vezes eu vou ate sete horas, mas é muito difícil. Normalmente até às seis horas até quatro hora da manhã, cinco hora da manhã, se tiver que pescar, tem que acordar quatro hora da manhã (est) no clarear do dia é melhor para pescaria. Tem determinado tipo de peixe que ainda só dá com escuro. Quando começa a clarear o dia, já os peixe já vão (hes) escapulindo, sai FORA. (est)

FORA11- F-(...) O "ônibus chega no ponto, principalmente essas linha aqui para o Rio, lá para [os]- (hes) os cafundó do judas lá de Caxias, eu não sei, mas aqui para a cidade, entra quatro, cinco seis, oito, dez passageiro, no máximo, o “ônibus está saindo, (est) é entra outro "ônibus". É uma beleza! aqui não, aqui é filas é mais fila de passageiro esperando o "ônibus. (est) É o "ônibus passa FORA assim- é esse problema nunca ninguém- eu não sei, às vezes um fala, coisa é tal, mas resolver nunca [ninguém resolveu.] cada vez pior.

FORA6- F- [Isso é] patriotismo! O cara vai para ali para jogar como brasileiro. que eu acho que uma copa do mundo é uma guerra. Se foi escolhido uma seleção, eles têm alí para- ele tem que ir lá para lutar pelo Brasil. Esse é meu raciocínio! Deixa os interesse monetário de FORA!

FORA3- Do espaço físico para o temporal:

F- [Carnaval também] já não é mais como antigamente. Há muita desonestidade, não há mais confiança, a gente não pode mais brincar um carnaval, você está arriscado a ser assassinado, roubado, não e como antigamente. [não é] só o carnaval não! FORA do carnaval a gente não tem mais confiança. outro dia mesmo, eu fui assaltado num "ônibus aí. Me levaram o relógio.

\section{Informante Jan - Recontato - 15 ocorrências}

FORA11- F: O que eu me lembro do caso mais ou menos foi isso, hoje, talvez não aconteça isso porque, hoje, cobertura de circo ,não sei se é a mesma, parece que é lona. Lona se você jogar um ... uma estopa queimando, aquilo fica queimando ali, [vai queimando devagar]... vai queimando devagar, então, até cobrir dá tempo [de]... de (est) quem tiver lá sair FORA, mas (naquele)... (naquele)... naquela época parece que era um troço que (imita o barulho do fogo se alastrando) colou, queimou tudo(hes). Parece que era assim, não tô lembrando bem.

FORA11- F: [ Tenho ]... tenho irmão, não são muitos, mas tenho; tenho dois filhos... tenho um casal; tenho três netos (hes) meu filho é que não vive no Brasil, tá FORA do Brasil. 
FORA11- F: Não. Eu tive um irmão que (hes) morreu há muito tempo de acidente, era o que eu mais tinha contato porque nós saíamos, viajávamos, trabalhávamos FORA, na cidade Sempre vivi muito junto com ele, mas com [ os outros não ]... os outros não, tenho contato com eles e tal, visito, vejo sempre e tudo, mas o que eu tive mais intimidade foi esse que morreu, mas há muitos anos.

FORA1- F: Aí, a gente sai a vontade e tudo, vai embora, vai por esses oceano todo, mas quando você tá lá $\boldsymbol{F O R A}$ no alto-mar, na hora de voltá:, o mar agitá, você tem que voltá, você não pode ficá lá:, 'pô' (hes).

FORA11- F: (...)Você tá lendo, sai da igreja, sai, já rezou, tá todo mundo ali, aquela coisa toda, sai da igreja, chegou em casa o: ... chegou lá e viu que o gato comeu um peixe seu, tu botou vene:no prá ele. Aquilo tudo que você fez ali jogou FORA, porque o GATO (hes)... A lei da vida é essa, 'pô'! :

FORA4- F: Não. A última ... as últimas participações de [grandes] ... grandes (hes) [do] ... do esporte brasileiro foi agora na França, né ? [de] ... de ... do Guga e do Fernando Meligeni. Eu acho que aí, num houve marmelada não. Perdeu porque num tinha que ganhá mesmo. Tênis num é brincadeira, não. E foi a única coisa que eu participei [do] ... do esporte. FORA disso, eu me desliguei um pouco. Desde a Copa do Mundo, eu passei a num acreditá muito em honestidade. Eu acho que existe muita maracutaia nesse campo, mas agora a última participação [nesses grandes] ... nesses grandes esportes $\neg-$ é: foi agora nu Tênis, né ?, do Guga e do Fernando Meligeni

FORA11- F. (...). Eu gosto muito de música, eu adoro música, mas tem que sê coisa boa; se fô música porcaria ...(est) Cum essas porcaria, num adianta que eu num jogo meu dinheiro FORA não. Artista que num fô artista MESMO, comigo ele num se cria.

FORA4- F: (...) Ho:je, só tomo banho de mar quando tivé pescando, que aí eu sou obrigado a me molhá, né ? FORA disso, num vou à praia ; pode tá o maior calor; por aqui, (aponta pela janela) tá cheio isso aí, eu num vou lá.

FORA11- F: Não, eu como em restaurante, (est) eu como em pensão e num suporto fazê comida, lavá louça, lavá panela, cuidá de casa, nada disso. Tudo isso, eu pago FORA, (est) prá isso é que eu trabalho um pouco mais.

FORA11 e FORA2-F: Nada. Se eu tivé que fazê uma posta, morrê de fome eu num vou; fazê um arroz, uma coisa, isso eu faço, mas num tenho necessidade, prefiro pagá e sai muito mais barato prá mim e sem trabalho. (est) E, se eu fosse acompanhado, também tivesse uma companheira e tudo, acho que ainda era mais vantagem pagá FORA que fazê em casa. (est) Comida num é cara não, comida aqui no Brasil; num sei lá $\boldsymbol{F O R A}$ que eu nunca fui a país nenhum, que seja aí prá $\boldsymbol{F O R A}$, a num ser aqui por perto - Paraguai, Argentina, essa coisa toda aí. Eu acho que a comida no Brasil num é cara não. Eu tenho a impressão de que aí prá FORA, nesses países da Europa, Estados Unidos, tudo isso, eu acho que é muito mais caro. Muita gente acha que num é não. Tem gente que vai lá prá FORA, mas si num economizá, vai voltá do mesmo jeito que foi. (est) Pensá que lá come a vontade, que esperdiça como aqui, (riso F.) tá perdido.

Informante Jup- contato - 11 ocorrências 
FORA11- F-(...)- (inint) Ficar dentro de casa, trancar a ("porta") ficar dentro de casa. Nem vai abrir a porta para sair para FORA. Eles invade, até, o nosso quintal. Se a gente tiver com a porta aberta eles entra e tudo, é um perigo, não é, a gente dentro de casa, vem uma bala,

FORA11- F- (...) A casa da minha colega caiu. Ela com as criança dentro de casa ela escutou estalando <traaa $>$ ! Quando ela escutou $<$ trec $>$ ela agarrou os filho e caiu FORA. Quando ela acabou de sair a casa caiu também. Por isso que é perigoso. Foi uma chuvinha que teve. Ficou chovendo: segunda, terça, quarta, quinta. Aquela chuvinha: só pintainho, pintainho

FORA11- F- Se davam, se dava muito bem meu pai e minha mãe. Eles nunca brigaram. Aqui dentro da minha casa nunca vi um tumulto deles dois, sabe? Nunca brigaram, nunca se aborreceram. Às vezes que ela falava um pouco mais alto do que ele, ele saía FORA. Porque ele meu pai não gosta de briga. Ele corre de briga. Ele saía FORA, deixava ela falando sozinho.

FORA11- F- (...) O meu irmão de vinte e dois estava para rua também. Estava todo mundo FORA. Meu pai estava trabalhando e tinha um primo meu aqui em casa dormindo. ("ai") Ela foi ali numa tendia que tinha ali, aí <comp.-> pediu querosene, o moço disse que não tinha.

FORA11- F- (...)Aí cheguei no Andaraí, esperei eles tudo sair (choro de criança) o meu pai também ia [do] do serviço para o hospital, não é? Podia entrar todo dia. Ela estava no CTQ. Aí eu falei: "eu vou ver minha mãe." Só podia entrar uma pessoa. Eu falei: "eu vou na frente, eu entro, quando ele chegar eles não pode entrar, eu já estou lá em cima." Aí saí de casa quietinha, me arrumei, saí FORA. Cheguei lá, falei com a moça, aí expliquei ela, (grito de criança) mas calminha, se não eles não deixava eu entrar, não.

FORA11- F: (...) . Daqui a pouco eu boto a lata na cabeça, ("aí escutei") gritar: "Jupira, corre!" Quando falou: Jupira corre, eu vim com a lata d'água, joguei a lata d'água FORA. Já não tinha muita água em casa, joguei a lata, ah, não queria saber. Joguei a água FORA. Quando eu vi um papel, assim, na mão da moça, ah, aquilo me apavorou!

FORA11- F- (...) Quando faltou um domingo para ver a festa, eu saí FORA. [’ainda não foi a][Porque] tiraram meu par, aí eu falei: "não vou dançar". Aí, não dancei. Tiraram ele me deram outro, falei: "não vou dançar, nada." Aí, saí. Já estava com a caipira pronta. Minha mãe tinha comprado a maria-mole, a meia, o chapéu é. Saí FORA, não dancei, nada, ("caiu") FORA. (inint) "Então vou namorar."

\section{Informante Jup- recontato - 7 ocorrências}

FORA11- F: Ah, com o outro. Mas eu tinha medo do outro. Engraçado. Num sei porque com Dau eu não tenho medo não, mas com Bras eu tinha medo eu nem falava ele que ia pra toda e qualquer direção. E por causa disso eu aprendi muito, então agora eu falo, né? eu já comecei falano. Logo assim que eu comecei com Dau eu já queria logo direto, aí ele ficava me olhano aí com o Bras eu já num falava, ele chegava, eu sentava no ... reprendida começava a chorá. Ou então jogava alguma coisa nele, ele tacava FORA. 
FORA2-F: É geralmente no, no samba tem muita gente de FORA, né? (est) tem gente daqui mesmo. O que que... como é que você acha que eles sambam? por exemplo os estrangeiros as pessoas que não são daqui do Rio, ou que mesmo não são da comunidade...?

FORA2-F: Ah, é muito legal. Eles se entrosam muito legal chegam conversam, pergunta como é que faz pra conseguir fantasia, eu acho legal, que o pessoal de FORA que que vêem pra escola, assim visitar, pôxa, eu acho legal porque eles ficam interessados em sabé como é que a gente consegue fantasias, se é de graça, como é que faz pra pagá, eu acho legal.

FORA6- F: Na hora não cantam, não evolui. Então atrapalha bem a gente, que a gente tamos acostumado a chegá no samba se evoluí, e tal. Chega lá na Marquês tamos lá querendo se evoluí, e a gente querendo se mexe mas aí não dá porque ele não conseguem pegá porque eles dão uma coreografia pra gente fazé e tal e levanta a mão, chega lá eles não sabem, eles não sabem pegá nada então começa a atrapalhá aí a gente começa a entrá na bagunça deles também. Porque é três quatro da comunidade pra vinte trinta de FORA, então atrapalha à beça, mas eu acho legal.

FORA11- F: Corre. Até hoje ele (inint) "ah, vocês erraram no molequinho também erraram. Aonde me vê, oh (estala os dedos) "sarta" FORA. Aí ficou aquele negócio de resistro do neném, resistra, não resistra, resistra não resistra, eu falei: "Suele, você qué que eu resistro?" Que eu ía resistra o menino. Ela: "Ah, mãe resistra."

FORA2- F: Eu não queria essa criança pra mim. Mas ela é chata demais, é o dia inteiro agarrada no peito. Tem um ano e sete meses, a menina não come uma colhé de comida. [É o dia inteiro] ela bota o mama da mãe dela pra $\boldsymbol{F O R A}$, enfia a mão no outro, enfia mão no outro levanta as pernas lá pra cima (risos) e aí, e aí fica o dia inteiro aí, então a Cynthia deita bota o mamá lá na cama e ali ela fica o dia inteiro. Não come duas colhé de comida, ela tem um ano e sete meses, ela parece (inint)

FORA1- F: Leite caro ruim e a Catherine não tomô. Ela tomô mas botô tudo pra FORA, não aceitou leite nenhum. Ela não gosta de leite. Ela não toma danone, [toda as criança adora danone] e a "Catherine" odeia danone. A gente às vezes passa o dedo, ele (cuspindo) ...

\section{Informante Lei- contato - 3 ocorrências}

FORA1- F- Ah! O barulho, o silêncio lá, sabe? Aqui para dormir, inclusive, a gente que mora ali em frente ... padaria, assim- de vez em quando, aquelas criança- os rapazes ali da vila vão tudo para lá , ali para o portão, aí fica uma <gritalhada>, fica mexendo com os outro, joga pedra, ...às vezes tu quer dormir não pode, tem que ir lá FORA reclamar com eles. Lá não. Onde minha irmã mora não. Fechou a porta, pronto, não escuta nem barulho de carro, nem nada- um silêncio danado. (está)

FORA11- F: A gente fala: "Ah! não joga pedra!"'Ah! <mo->-" eles em vez de chegar aí no portão: "Ah! A senhora me deixa eu subir na mangueira, tirar uma manga? "A senhora deixa eu com bambú tirar uma manga?" "Tudo bem, a gente deixa. Porque cai 
lá no chão, a gente joga FORA mesmo. Porque não acha ninguém para subir ali. Aí, jogam pedra, cai pedra em cima do telhado, quebra telha.

FORA1- F- "Ah! Pode deixar minha filha!" ele ficava em cima do portão, para o lado de dentro. Porque, se ele ficasse do lado de FORA, o- era capaz do carro pegar ele ali.

\section{Informante Lei- recontato - 4 ocorrências}

FORA4- F: Só quando tem, assim, um... (hes) tem que almoçar, por exemplo, veio oitava série, olha, eles ligam tá?, pra falá "Leila, olha, tem mais cinco pessoa prá almoçá." Da oitava série, sabe, eles já pagam lá separado. FORA disso não. Do CA à Quarta série.

FORA1- F: Olha, cê sabe que num dá prá mim vê direito porque eu fico (hes) eu pego oito horas, entro lá pro meu setor, [só saio quase] só saio duas hora prá batê o ponto, aí volto pro meu setor, fico lá dentro, leio jornal, conversando, aí volto três hora, bato o meu ponto na entrada do almoço. Entro e só saio na hora de i embora. Quase num vejo segundo grau, sabe?, lá FORA, quase num vejo.

FORA11- F: Eu fico mais na minha mãe também porque eu ultimamente eu tô fazeno um negócio de uns congelado, né?, faço uns congelado prá FORA, quer dizer, e eu fíco aqui porque aqui é mais espaçoso que na minha casa.

FORA11- F: Lembro não. Daí não, eu num me lembro porque ficava com a [minha] (hes) minha mãe morava lá, minha mãe trabalhava FORA, entendeu?, levava eu e minha irmã...num lembro muito bem não.

FORA4- F: (...) Ficou de cara amarrada comigo, eu pedi uma coisa a ela, ela da pia dela prá minha ela jogou. Aí eu falei prá ela: "Vem cá, o que que eu te fiz? Nunca te fiz nada, entendeu?, sempre te tratei bem, por que você me tratou com essa ignorância? Porque eu falei pro patrão que sumiu uma coisa aqui? Mas eu tenho que falá, senão vai saí do meu bolso ou então do seu e da nutricionista. A gente já num ganha bem." Mas FORA disso....só foi isso....agora já tá bem. Já passou. 